\title{
Total Synthesis of Eustifolines A-D and Glycomaurrol via a Divergent Diels-Alder Strategy
}

\author{
Supporting Information \\ Terry P. Lebold and Michael A. Kerr* \\ The University of Western Ontario, Department of Chemistry, \\ London, Ontario, Canada N6A 5B7

\section{Table of Contents}

General Experimental

Experimental procedures and characterization data

Spectra page $\mathrm{S}-2$

page $\mathrm{S}-2-\mathrm{S}-13$

page $\mathrm{S}-14-\mathrm{S}-51$ 


\section{Experimental}

\section{General}

Melting points were determined using a Gallenkamp melting point apparatus and are uncorrected. Infrared spectra were obtained as thin films on $\mathrm{NaCl}$ plates using a Bruker Vector 33 FT-IR instrument. NMR experiments were performed on Varian Mercury 400, Varian Inova 600 and Inova 400 instruments and samples were obtained in $\mathrm{CDCl}_{3}$ (referenced to $7.26 \mathrm{ppm}$ for ${ }^{1} \mathrm{H}$ and 77.0 for ${ }^{13} \mathrm{C}$ ) or Acetone- $\mathrm{d}_{6}$ (referenced to 29.8 for ${ }^{13} \mathrm{C}$ ). Coupling constants (J) are in Hz. The multiplicities of the signals are described using the following abbreviations: $\mathrm{s}=$ singlet, $\mathrm{d}=$ doublet, $\mathrm{t}=$ triplet, $\mathrm{q}=$ quartet, sept $=$ septuplet, $\mathrm{m}=$ multiplet, $\mathrm{br}=$ broad. High resolution mass spectra (HRMS) were obtained on a Finnigan MAT 8200 spectrometer at $70 \mathrm{eV}$.

Toluene, pentane, tetrahydrofuran (THF), ether, dioxane, and dichloromethane (DCM) were dried and deoxygenated by passing the nitrogen purged solvents through activated alumina columns. All other reagents and solvents were used as purchased from Aldrich, Strem, Caledon or VWR. Reaction progress was followed by thin layer chromatography (TLC) (EM Science, silica gel $60 \mathrm{~F}_{254}$ ) visualizing with UV light, and the plates developed using acidic anisaldehyde. Flash chromatography was performed using silica gel purchased from Silicycle Chemical Division Inc. (230-400 mesh). Preparative TLC was performed on glass backed $0.25 \mathrm{~mm}$ silica plates (Rose Scientific, silica gel $60 \mathrm{~F}_{254}$ ).

Quinone imine 8 was prepared using the literature procedure. ${ }^{1}$

Diene 9 was used as a crude mixture without purification and was prepared as follows. Vinylmagnesium chloride (100 ml of $1.6 \mathrm{M}$ solution in THF, $160.000 \mathrm{mmol}$ ) was added to $\mathrm{Et}_{2} \mathrm{O}$ $(200 \mathrm{ml})$ and cooled to $0{ }^{\circ} \mathrm{C}$. 4-methylcyclohexanone (15 ml, $\left.122.225 \mathrm{mmol}\right)$ was then added dropwise and the solution allowed to warm to room temperature and stir for a period of 12 hours. Water followed by $5 \% \mathrm{HCl}$ solution was then added to quench the reaction. The reaction was poured into water and extracted 3 times with $\mathrm{Et}_{2} \mathrm{O}$. The combined organics were washed twice with water, once with brine, and dried with $\mathrm{MgSO}_{4}$. The solvent was removed under reduced pressure to yield the crude alcohol as mixture of diasteriomers $\left[{ }^{1} \mathrm{H}-\mathrm{NMR}\right.$ key resonances (400 $\mathrm{MHz}, \mathrm{CDCl}_{3}$ ): $\delta=6.71,5.93$ (2dd, $\left.\mathrm{J}=17.4,10.8 \mathrm{~Hz}, 1 \mathrm{H}\right), 5.30,5.22$ (2dd, $\mathrm{J}=17.4,1.2 \mathrm{~Hz}, 1 \mathrm{H}$ ), 5.13, 4.99 (2dd, $\mathrm{J}=10.8,1.6 \mathrm{~Hz}, 1 \mathrm{H})$ ]. The crude alcohol was redissolved in pentane (250 ml) and paratoluenesulfonic acid (4.65 g, $24.445 \mathrm{mmol}$ ) was added and the mixture brought to reflux for 12 hours, after which $\mathrm{H}^{1}$ NMR showed that starting material still remained. Paratoluenesulfonic acid (2.00 g, $10.514 \mathrm{mmol})$ was added and the mixture refluxed for an additional 2.5 hours, after which $\mathrm{H}^{1}$ NMR showed complete consumption of the starting material. The organic layer was decanted off and the aqueous residual rinsed 3 times with pentane. The combined organics were washed three times with saturated $\mathrm{NaHCO}_{3}$ solution, once with brine, and dried with $\mathrm{MgSO}_{4}$. The solvent was removed under reduced pressure to yield the crude diene 9 which was used directly in the Diels-Alder reaaction $\left[{ }^{1} \mathrm{H}-\mathrm{NMR}\right.$ key resonances $(600 \mathrm{MHz}$, $\left.\mathrm{CDCl}_{3}\right): \delta=6.35$ (dd, J = 16.8, $\left.10.8 \mathrm{~Hz}, 1 \mathrm{H}\right), 5.74-5.70(\mathrm{~m}, 1 \mathrm{H}), 5.06$ (d, J = $\left.16.8 \mathrm{~Hz}, 1 \mathrm{H}\right), 4.89$ (d, $\mathrm{J}=10.8 \mathrm{~Hz}, 1 \mathrm{H})]$. 


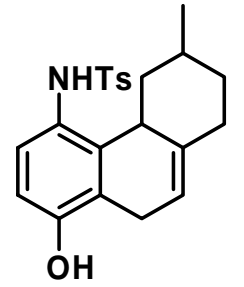

Compound 12

Quinone imine 8 (10.102 g, $38.661 \mathrm{mmol})$ and excess diene 9 were dissolved in DCM $(150 \mathrm{ml})$ and the reaction brought to reflux. The reaction was monitored by $\mathrm{H}^{1} \mathrm{NMR}$ and upon dissapearance of the quinone imine [peaks monitored for dissapearance: ${ }^{1} \mathrm{H}-\mathrm{NMR}\left(400 \mathrm{MHz}, \mathrm{CDCl}_{3}\right): \delta=8.22,8.22(\mathrm{~d}, 1 \mathrm{H}, \mathrm{J}=10.2,10.7$ $\mathrm{Hz}$, atropisomers), 6.99, 6.98 (d, $1 \mathrm{H}, \mathrm{J}=10.5,9.8 \mathrm{~Hz}$, atropisomers)] the reaction was cooled to room temperature and 5 drops of DBU were added. After 1 hour of $\mathrm{Hz}, 1 \mathrm{H})]$. The reaction mixture was then washed with $5 \% \mathrm{HCl}$ solution to remove DBU at which point some product began to crash out of solution. The aqueous fraction was extracted 3 times with DCM and the organic fractions combined and acetone was added to dissolve any precipitate. The crude product was then preabsorbed onto silica and purified by column chromatography on silica gel (acetone / hexanes as eluent) to yield phenol 12 (13.431 g, $35.022 \mathrm{mmol}, 91 \%$ ) as a tan solid and mixture of diasteriomers: $\mathrm{R}_{\mathrm{f}}=0.18,25 \%$ ethyl acetate in hexanes; ${ }^{1} \mathrm{H}-\mathrm{NMR}$ (600 $\left.\mathrm{MHz}, \mathrm{CDCl}_{3}\right): \delta=7.57,7.55(2 \mathrm{~d}, \mathrm{~J}=8.1 \mathrm{~Hz}, 2 \mathrm{H}), 7.22(\mathrm{~d}, \mathrm{~J}=8.1 \mathrm{~Hz}, 2 \mathrm{H}), 6.94,6.91(2 \mathrm{~d}, \mathrm{~J}=8.7$ $\mathrm{Hz}, 1 \mathrm{H}), 6.55$ (d, J = 8.7 Hz, 1H), 5.98, 5.99 (2s, 1H), 5.45, 5.44 (2s, 1H), 4.70 (s, 1H), 3.18 (AB, $2 \mathrm{H})$, 3.09-3.04, 2.85-2.80 (2m, 1H), 2.40, $2.39(2 \mathrm{~s}, 3 \mathrm{H}), 2.25-1.57$ (series of multiplets, $6 \mathrm{H}$ ), 1.44-1.39, 1.12-0.95 (2m, 1H), 1.20, $0.85(2 \mathrm{~d}, \mathrm{~J}=6.9 \mathrm{~Hz}, 3 \mathrm{H}) ;{ }^{13} \mathrm{C}$ NMR (100 MHz, Acetone- $\left.\mathrm{d}_{6}\right)$ $\delta=154.6,154.5,143.83,143.77,141.1,140.1,139.7,139.22,139.19,138.7,130.2,130.1,128.1$, 128.0, 127.8, 126.4, 126.3, 123.0, 122.6, 114.6, 114.0, 112.3, 112.2, 45.5, 42.8, 38.8, 38.6, 36.2, 35.6, 34.2, 33.7, 31.8, 30.6, 29.7, 25.8, 25.7, 22.3, 21.3, 18.0; IR (thin film): 3398, 3283, 2959, 2923, 2872, 2845, 1586, 1487, 1457, 1373, 1306, 1240, 1185, 1147, 1091, 1027, 896, 811, 669; HRMS calc'd for $\mathrm{C}_{22} \mathrm{H}_{25} \mathrm{NO}_{3} \mathrm{~S}=383.1555$, found $=383.1554$.

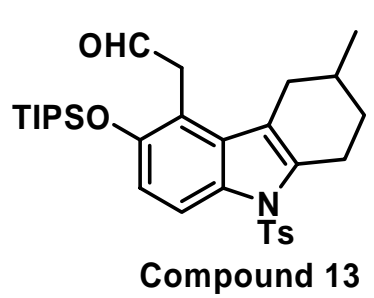

water and extracted 3 times with ethyl acetate. The combined organics were washed with water then brine, and dried with $\mathrm{MgSO}_{4}$. The solvent was removed under reduced pressure to produce a crude mixture that was purified by column chromatography on silica gel (ethyl acetate / hexanes as eluent) to yield the alkene intermediate $\mathbf{A}$ (1.093 g). Alkene intermediate A (1.093 g) was dissolved in a mixture of tBuOH $(8 \mathrm{ml})$, THF $(10 \mathrm{ml})$, and water $(1 \mathrm{ml})$. NMO (474 mg, 4.046 mmol) and a catalytic amount of $\mathrm{OsO}_{4}$ were then added and the reaction stirred at room temperature until TLC indicated the complete consumption of the starting material. Aqueous saturated sodium sulfite $(20 \mathrm{ml})$ was added and the solution stirred for one hour after which a small amount of $\mathrm{NaBH}_{4}$ was added until TLC showed only one spot $\left(\mathrm{R}_{\mathrm{f}}\right.$ of dihydroxyaled product $=0.1525 \%$ ethyl acetate in hexanes). The reaction was poured into water and extracted 4 times with ethyl acetate. The combined organics were washed with water then brine, and dried with $\mathrm{MgSO}_{4}$. The solvent was removed under reduced pressure to yield the crude diol as an off-white solid (1.162 g). The diol (1.162 g) was redissolved in DCM (35ml) and $\mathrm{NaIO}_{4} / \mathrm{SiO}_{2}(5.930 \mathrm{~g}$ of 
$0.683 \mathrm{mmol} / \mathrm{g} \mathrm{NaIO} / \mathrm{SiO}_{2}, 4.050 \mathrm{mmol}$ ) was added and the mixture stirred for 18.5 hours, after which TLC showed complete consumption of the diol. The reaction mixture was then filtered through a sintered glass funnel to remove the $\mathrm{NaIO}_{4} / \mathrm{SiO}_{2}$, washing with EtOAc. The solvent was removed under reduced pressure to produce a crude residue which was redissolved in THF (25 ml). 6 drops of concentrated sulfuric acid was then added and the reaction stirred for 1 hour, after which TLC showed only spot corresponding to the aldehyde 13. The solution was then neutralized with $\mathrm{Na}_{2} \mathrm{CO}_{3}$ and $\mathrm{MgSO}_{4}$ added to remove any water. The reaction mixture was then filtered, washing with EtOAc, and the solvent removed under reduced pressure to produce a crude solid that was purified by column chromatography on silica gel (DCM / hexanes as eluent) to yield aldehyde 13 (883 mg, $1.594 \mathrm{mmol}, 61 \%$ over 4 steps) as an off-white solid: m.p. = 168$171{ }^{0} \mathrm{C} ; \mathrm{R}_{\mathrm{f}}=0.65,20 \%$ ethyl acetate in hexanes; ${ }^{1} \mathrm{H}-\mathrm{NMR}\left(600 \mathrm{MHz}, \mathrm{CDCl}_{3}\right): \delta=9.68(\mathrm{t}, \mathrm{J}=$ $1.8 \mathrm{~Hz}, 1 \mathrm{H}), 7.99(\mathrm{~d}, \mathrm{~J}=8.7 \mathrm{~Hz}, 1 \mathrm{H}), 7.61(\mathrm{~d}, \mathrm{~J}=8.1 \mathrm{~Hz}, 2 \mathrm{H}), 7.19(\mathrm{~d}, \mathrm{~J}=8.1 \mathrm{~Hz}, 2 \mathrm{H}), 6.81(\mathrm{~d}, \mathrm{~J}$ $=8.7 \mathrm{~Hz}, 1 \mathrm{H}$ ), 4.02 (ABdd, $\mathrm{J}=16.5,2.1 \mathrm{~Hz}, 1 \mathrm{H}$ ), 3.95 (Abdd, $\mathrm{J}=16.5,2.1 \mathrm{~Hz}, 1 \mathrm{H}$ ), 3.14 (br.d, $\mathrm{J}$ $=17.4 \mathrm{~Hz}, 1 \mathrm{H}), 2.89-2.80(\mathrm{~m}, 2 \mathrm{H}), 2.34(\mathrm{~s}, 3 \mathrm{H}), 2.28-2.24(\mathrm{~m}, 1 \mathrm{H}), 1.92-1.88(\mathrm{~m}, 1 \mathrm{H}), 1.83-1.76$ (m, 1H), 1.43-1.36 (m, 1H), 1.33 (sept, J = , 3H), 1.10 (d, J = 7.8 Hz Hz, 18 H), 1.06 (d, J = 6.6 $\mathrm{Hz}, 3 \mathrm{H}) ;{ }^{13} \mathrm{C}$ NMR $\left(100 \mathrm{MHz}, \mathrm{CDCl}_{3}\right) \delta=200.6,150.8,144.4,136.5,136.0,131.4,130.6,129.7$, 126.3, 118.1, 114.3, 114.0, 113.5, 41.6, 32.6, 30.5, 28.8, 24.6, 21.5, 21.3, 18.0, 13.0; IR (thin film): 2947, 2868, 2719, 1726, 1598, 1473, 1432, 1370, 1263, 1177, 1092, 1057, 951, 925, 883, 812, 669; HRMS calc'd for $\mathrm{C}_{31} \mathrm{H}_{43} \mathrm{NO}_{4} \mathrm{SSi}=553.2682$, found $=553.2677$.

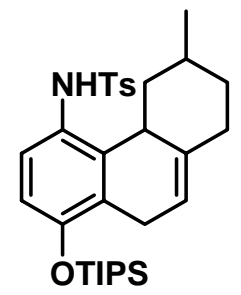

Light pink foam: $\mathrm{R}_{\mathrm{f}}=0.58,25 \%$ ethyl acetate in hexanes; ${ }^{1} \mathrm{H}-\mathrm{NMR}(600 \mathrm{MHz}$, $\mathrm{CDCl}_{3}$ ): $\delta=7.52,7.50$ (2d, J = 7.8 Hz, 2H), 7.18 (br.d., J = 7.8 Hz, 2H), 6.94, $6.92(2 \mathrm{~d}, \mathrm{~J}=8.4 \mathrm{~Hz}, 1 \mathrm{H}), 6.573,6.566$ (2d, J = 8.4 Hz, 1H), 6.05, 5.94 (2s, 1H), 5.45-5.42 (m, 1H), 3.20 (AB, 2H), 2.98-2.94, 2.77-2.73 (2m, 1H), 2.380, 2.375 (2s, 3H), 2.22-1.54 (series of multiplets, $6 \mathrm{H}), 1.42-1.36,1.00-0.92(2 \mathrm{~m}, 1 \mathrm{H})$, 1.278, 1.275 (2sept, J = 7.8 Hz, 3H), 1.19, 0.84 (2d, J = 7.5 Hz, 3H), 1.091, 1.086 Intermediate A $(2 \mathrm{~d}, \mathrm{~J}=7.5 \mathrm{~Hz}, 18 \mathrm{H}) ;{ }^{13} \mathrm{C} \mathrm{NMR}\left(100 \mathrm{MHz}, \mathrm{CDCl}_{3}\right) \delta=152.43,152.38,143.5$, 139.4, 138.6, 136.63, 136.55, 135.7, 135.4, 129.4, 129.3, 127.2, 127.1, 126.2, 126.0, 125.9, 125.4, 125.3, 115.4, 115.3, 114.2, 113.7, 44.9, 42.7, 38.1, 37.7, 35.3, 34.6, 33.6, 32.8, 30.8, 28.6, 26.0, 25.9, 21.9, 21.5, 18.0, 17.9, 17.7, 13.0, 12.25; IR (thin film): 3539, 3275, 2945, 2868, 1587, 1474, 1383, 1320, 1292, 1259, 1163, 1094, 1048, 1014, 974, 954, 883, 814, 764, 668; HRMS calc'd for $\mathrm{C}_{31} \mathrm{H}_{45} \mathrm{NO}_{3} \mathrm{SSi}=539.2889$, found $=539.2897$.

Carbazole 14 was prepared in three steps from aldehyde $\mathbf{1 3}$ without purification of the alcohol intermediate $\mathbf{B}$ or deprotected alcohol intermediate $\mathbf{C}$, as both intermediates were of high purity. For authenticative purposes a small amount of alcohol intermediate $\mathbf{B}$ was purified to allow full characterization. Deprotected alcohol intermediate $\mathbf{C}$ was not stable to silica gel and was characterized as is after work-up.

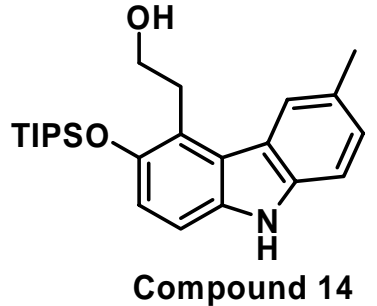

Aldehyde 13 (1.367 g, $2.468 \mathrm{mmol})$ was dissolved in a mixture of methanol $(10 \mathrm{ml})$ and THF $(20 \mathrm{ml})$ and cooled to $0{ }^{\circ} \mathrm{C}$. $\mathrm{NaBH}_{4}(112 \mathrm{mg}$, $2.961 \mathrm{mmol}$ ) was then added and the solution stirred for 1 hour, after which TLC indicated complete consumption of the starting material. Water and $5 \% \mathrm{HCl}$ solution were then added to quench the reaction. The reaction was poured into water and extracted 3 times with ethyl acetate. 
The combined organics were washed with water then brine, and dried with $\mathrm{MgSO}_{4}$. The solvent was removed under reduced pressure to produce crude alcohol intermediate $\mathbf{B}(1.384 \mathrm{~g})$ as a white foam. Crude alcohol intermediate B (1.384 g) was dissolved in a mixture of methanol (15 $\mathrm{ml}$ ) and THF (15 ml). Magnesium (600 g, $24.681 \mathrm{mmol}$ ) and $\mathrm{NH}_{4} \mathrm{Cl}$ (264 mg, $4.936 \mathrm{mmol}$ ) were added and the mixture allowed to stir for 5.5 hours, after which TLC showed complete consumption of the starting material. The reaction was poured into saturated $\mathrm{NH}_{4} \mathrm{Cl}$ solution and extracted 3 times with ethyl acetate. The combined organics were washed twice with water, once with brine, and dried with $\mathrm{MgSO}_{4}$. The solvent was removed under reduced pressure to produce crude deprotected alcohol intermediate $\mathbf{C}(978 \mathrm{mg})$ as a white-brown solid. The crude deprotected alcohol intermediate $\mathbf{C}(978 \mathrm{mg})$ and $\mathrm{NEt}_{3}(0.5 \mathrm{ml})$ was dissolved in mesitylene (18 $\mathrm{ml}) .10 \% \mathrm{Pd} / \mathrm{C}(490 \mathrm{mg}$ ) was added and the mixture brought to reflux for 14 hours, after which TLC showed complete consumption of starting material. The reaction was then cooled to room temperature (reaction mixture was loaded directly onto column without removal of solvent) and purified by column chromatography on silica gel (ethyl acetate / hexanes as eluent) to yield carbazole 14 (876 mg, $2.203 \mathrm{mmol}, 89$ \% over three steps) as a very pale yellow solid: m.p. = 86$89{ }^{0} \mathrm{C} ; \mathrm{R}_{\mathrm{f}}=0.36,20 \%$ ethyl acetate in hexanes; ${ }^{1} \mathrm{H}-\mathrm{NMR}\left(600 \mathrm{MHz}, \mathrm{CDCl}_{3}\right): \delta=7.96(\mathrm{~s}, 1 \mathrm{H})$, 7.84 (s, 1H), 7.30 (d, J = 8.4 Hz, 1H), 7.22 (d, J = 8.4 Hz, 1H), 7.13 (d, J = 9.0 Hz, 1H), 6.96 (d, J $=9.0 \mathrm{~Hz}, 1 \mathrm{H}), 4.06(\mathrm{dt}, \mathrm{J}=6.6,5.4 \mathrm{~Hz}, 2 \mathrm{H}), 3.61(\mathrm{t}, \mathrm{J}=6.6 \mathrm{~Hz}, 2 \mathrm{H}), 2.53(\mathrm{~s}, 3 \mathrm{H}), 1.78(\mathrm{t}, \mathrm{J}=5.4$ $\mathrm{Hz}, 1 \mathrm{H}), 1.37$ (sept, J =7.8 Hz, 3H), 1.15 (d, J = 7.8 Hz, 18H); ${ }^{13} \mathrm{C}$ NMR $\left(100 \mathrm{MHz}, \mathrm{CDCl}_{3}\right) \delta=$ 147.3, 138.7, 135.0, 128.1, 126.7, 123.4, 122.7, 122.2, 122.0, 116.8, 110.3, 108.6, 62.4, 30.6, 21.6, 18.1, 13.1; IR (thin film): 3558, 3412, 3309, 3039, 2945, 2891, 2868, 2728, 1586, 1496, $1467,1447,1385,1327,1282,1265,1222,1150,1101,1037,1016,998,950,909,884,825$, 802, 734, 718, 683, 650; HRMS calc'd for $\mathrm{C}_{24} \mathrm{H}_{35} \mathrm{NO}_{2} \mathrm{Si}=397.2437$, found = 397.2424.

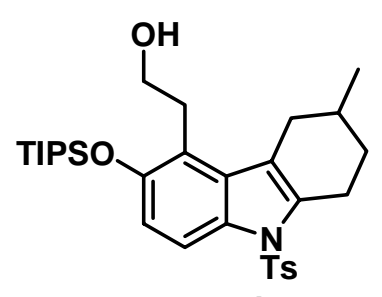

Intermediate B

White foam: m.p. $=148-150{ }^{0} \mathrm{C} ; \mathrm{R}_{\mathrm{f}}=0.31,20 \%$ ethyl acetate in hexanes; ${ }^{1} \mathrm{H}-\mathrm{NMR}\left(600 \mathrm{MHz}, \mathrm{CDCl}_{3}\right): \delta=7.91(\mathrm{~d}, \mathrm{~J}=9.0 \mathrm{~Hz}, 1 \mathrm{H}), 7.60$ (d, J = 9.0 $\mathrm{Hz}, 2 \mathrm{H}), 7.17$ (d, J = 9.0 Hz, 2H), $6.76(\mathrm{~d}, \mathrm{~J}=9.0 \mathrm{~Hz}, 1 \mathrm{H}), 3.81(\mathrm{t}, \mathrm{J}=6.9$ Hz, 2H), 6.96 (t, J = 6.9 Hz, 2H), 3.14 (br.d, J = $18.0 \mathrm{~Hz}, 1 \mathrm{H}), 2.97$ (dd, J $=16.2,4.8 \mathrm{~Hz}, 1 \mathrm{H}), 2.90-2.83(\mathrm{~m}, 1 \mathrm{H}), 2.39-2.35(\mathrm{~m}, 1 \mathrm{H}), 2.34(\mathrm{~s}, 3 \mathrm{H})$, 1.93-1.87 (m, 1H), 1.86-1.79 (m, 1H), 1.67 (br.s, 1H), 1.44-1.38 (m, 1H), 1.33 (sept, $\mathrm{J}=7.5 \mathrm{~Hz}, 3 \mathrm{H}), 1.11$ (dd, $\mathrm{J}=7.5,2.7 \mathrm{~Hz}, 18 \mathrm{H}), 1.07$ (d, J = 6.0 $\mathrm{Hz}, 3 \mathrm{H}) ;{ }^{13} \mathrm{C}$ NMR $\left(100 \mathrm{MHz}, \mathrm{CDCl}_{3}\right) \delta=150.6,144.3,136.01,135.98,131.4,130.4,129.7$, 126.3, 119.5, 118.7, 114.6, 112.9, 63.3, 32.7, 30.6, 29.6, 28.9, 24.7, 21.5, 21.4, 18.1, 13.1; IR (thin film): 3571, 3417, 2947, 2868, 1598, 1471, 1430, 1369, 1264, 1200, 1175, 1152, 1135, 1110, 1092, 1064, 1041, 1017, 988, 953, 926, 883, 810, 739, 704, 668, 602; HRMS calc'd for $\mathrm{C}_{31} \mathrm{H}_{45} \mathrm{NO}_{4} \mathrm{SSi}=555.2839$, found $=555.2847$.

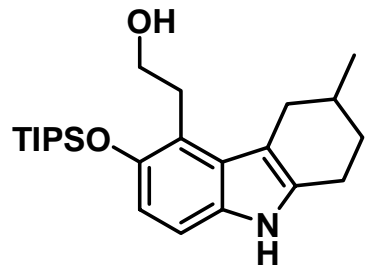

Intermediate C

Off-white solid: m.p. $=136-139{ }^{0} \mathrm{C} ; \mathrm{R}_{\mathrm{f}}=0.40,20 \%$ ethyl acetate in hexanes; ${ }^{1} \mathrm{H}$-NMR $\left(400 \mathrm{MHz}, \mathrm{CDCl}_{3}\right): \delta=7.56$ (br.s, $\left.1 \mathrm{H}\right), 6.97$ (d, J = 8.8 $\mathrm{Hz}, 1 \mathrm{H}), 6.66(\mathrm{~d}, \mathrm{~J}=8.8 \mathrm{~Hz}, 1 \mathrm{H}), 3.90(\mathrm{t}, \mathrm{J}=6.4 \mathrm{~Hz}, 2 \mathrm{H}), 3.31(\mathrm{dt}, \mathrm{J}=6.4$ $\mathrm{Hz}, 1.6 \mathrm{~Hz}, 2 \mathrm{H}$ ), 3.08 (dd, J = 15.2, $4.8 \mathrm{~Hz}, 1 \mathrm{H}), 2.81-2.65$ (m, 2H), 2.74 (dd, J = 15.2, 9.6 Hz, 1H), 1.96-1.87 (m, 2H), 1.83 (br.s, $1 \mathrm{H}), 1.57-1.45$ (m, 1H), 1.34 (sept, J = 7.4 Hz, 3H), 1.14-1.11 (m, 21H); ${ }^{13} \mathrm{C}$ NMR $(100$ $\left.\mathrm{MHz}, \mathrm{CDCl}_{3}\right) \delta=147.5,134.9,131.4,127.7,118.5,112.8,109.7,108.5$, 63.9, 32.3, 30.8, 30.15, 30.09, 23.3, 21.9, 18.2, 13.2; IR (thin film): 3390, 3330, 2945, 2925, 2891, 2867, 1583, 1486, 1463, 1429, 1384, 1318, 1294, 1262, 1237, 1222, 1185, 1138, 1104, 
1040, 1015, 997, 950, 938, 925, 882, 855, 791, 747, 701, 679, 638; HRMS calc'd for $\mathrm{C}_{24} \mathrm{H}_{39} \mathrm{NO}_{2} \mathrm{Si}=401.2750$, found $=401.2761$.

Aldehyde intermediate $\mathbf{D}$ was generally not subjected to purification by column chromatography on silica gel as simple filtration using a sintered glass funnel provided sufficiently pure aldehyde. However, in this case for authenticative purposes the aldehyde was subjected to column chromatography on silica gel.

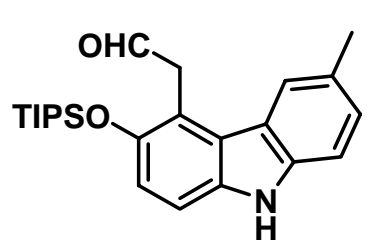

Intermediate D

The procedure is taken from literature ${ }^{2}$ with modifications to stoichiometry and isolation. Carbazole 14 (303 mg, $0.762 \mathrm{mmol})$ was dissolved in EtOAc ( $8 \mathrm{ml})$. IBX (427 mg, $1.524 \mathrm{mmol}$ ) was added and the mixture refluxed for 75 minutes, after which TLC showed complete consumption of the starting material. The reaction was filtered through a sintered glass funnel to remove the excess IBX and its byproducts washing with EtOAc. The solvent was removed under reduced pressure to produce the crude aldehyde which was purified by column chromatography on silica gel (DCM / hexanes as eluent) to yield aldehyde intermediate $\mathbf{D}$ (247 mg, $0.628 \mathrm{mmol}, 82 \%)$ as a yellow-brown sticky solid-oil: $\mathrm{R}_{\mathrm{f}}=$ 0.50, $20 \%$ ethyl acetate in hexanes; ${ }^{1} \mathrm{H}-\mathrm{NMR}\left(600 \mathrm{MHz}, \mathrm{CDCl}_{3}\right): \delta=9.79(\mathrm{t}, \mathrm{J}=2.4 \mathrm{~Hz}, 1 \mathrm{H})$, 7.93 (br.s, $1 \mathrm{H}$ ), 7.84 (s, 1H), 7.29 (d, J = $9 \mathrm{~Hz}, 1 \mathrm{H}), 7.23-7.21$ (m, 2H), 7.02 (d, J = 9 Hz, 1H), 4.33 (d, J = 2.4 Hz, 2H), 2.51 (s, 3H), 1.37 (sept, J = 7.8 Hz, 3H), 1.14 (d, J = 7.8 Hz, 18H); ${ }^{3} \mathrm{C}$ NMR $\left(100 \mathrm{MHz}, \mathrm{CDCl}_{3}\right) \delta=200.8,147.8,138.7,134.8,128.5,127.1,123.24,123.17,122.0$, 116.7, 115.8, 110.3, 109.8, 42.4, 21.6, 18.1, 13.1; IR (thin film): 3414, 3034, 2946, 2894, 2868, 2726, 1721, 1586, 1496, 1464, 1446, 1385, 1325, 1291, 1267, 1224, 1150, 1098, 1073, 1015, 998, 942, 883, 824, 802, 682; HRMS calc'd for $\mathrm{C}_{24} \mathrm{H}_{33} \mathrm{NO}_{2} \mathrm{Si}=395.2281$, found $=395.2272$.

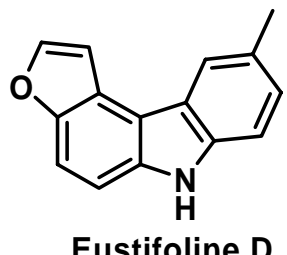

Eustifoline D was prepared in two steps from purified aldehyde intermediate D, without purification of the intermediate hemi-acetal. Aldehyde intermediate D $(0.247 \mathrm{~g}, 0.624)$ was dissolved in THF $(15 \mathrm{ml})$. TBAF $(1.25 \mathrm{ml}$ of $1.0 \mathrm{M}$ solution in THF, $1.250 \mathrm{mmol}$ ) was added dropwise and the solution stirred for 1 hour, after which TLC showed complete consumption of the starting material. $5 \% \mathrm{HCl}$ solution $(5 \mathrm{ml})$ was added to quench the reaction. The reaction was poured into water and extracted 4 times with ethyl acetate. The combined organics were washed with brine and dried with $\mathrm{MgSO}_{4}$. The solvent was removed under reduced pressure to yield the crude hemi-acetal $\left(\mathrm{R}_{\mathrm{f}}=0.12,20 \%\right.$ ethyl acetate in hexanes) as a dark solid. To this dark solid was added toluene (20ml) and paratoluenesulfonic acid (0.048 g, $0.252 \mathrm{mmol}$ ) and the mixture brought to reflux for 30 minutes, after which TLC showed complete consumption of the hemi-acetal. The reaction was cooled to room temperature and the solvent removed under reduced pressure to produce a crude solid that was purified by column chromatography on silica gel (ethyl acetate / hexanes as eluent) to yield Eustifoline D (0.095 g, $0.407 \mathrm{mmol}, 65 \%$ ) as a white solid. The spectroscopic data for synthetic Eustifoline D is in full agreement with literature ${ }^{4,6}$. however, there is a discrepancy in the melting point ${ }^{6}$ : m.p. $=181-184{ }^{0} \mathrm{C} ; \mathrm{R}_{\mathrm{f}}=0.43$, $20 \%$ ethyl acetate in hexanes; ${ }^{1} \mathrm{H}-\mathrm{NMR}\left(600 \mathrm{MHz}, \mathrm{CDCl}_{3}\right): \delta=8.09$ (br.s, $1 \mathrm{H}$ ), 7.98 (s, $1 \mathrm{H}$ ), 7.81 (d, J = 2.4 Hz, 1H), 7.58 (d, J = $9.0 \mathrm{~Hz}, 1 \mathrm{H}), 7.40$ (d, J = $8.4 \mathrm{~Hz}, 1 \mathrm{H}), 7.35$ (d, J = 9.0 Hz, 1H), 7.34-7.33 (m,1H), $7.27(\mathrm{~d}, \mathrm{~J}=8.4 \mathrm{~Hz}, 1 \mathrm{H}), 2.59(\mathrm{~s}, 3 \mathrm{H}) ;{ }^{13} \mathrm{C}$ NMR $\left(100 \mathrm{MHz}, \mathrm{CDCl}_{3}\right) \delta=$ 
150.3, 145.1, 137.7, 135.9, 128.7, 126.5, 123.2, 120.9, 120.4, 114.8, 110.4, 109.4, 107.4, 105.4, 21.5; IR (thin film): 3408, 3141, 2918, 2857, 1485, 1432, 1360, 1302, 1276, 1242, 1142, 1078, 1053, 947, 887, 808, 753, 737; HRMS calc'd for $\mathrm{C}_{15} \mathrm{H}_{11} \mathrm{NO}=221.0841$, found $=221.0836$.

Glycomaurrol was prepared in three steps from carbazole $\mathbf{1 4}$ without purification of the aldehyde intermediate $\mathbf{D}$ or alkene intermediate $\mathbf{E}$, as the crude aldehyde intermediate $\mathbf{D}$ was of sufficient purity and removal of the TIPS group of the alkene intermediate $\mathbf{E}$ allowed for greater ease in the isolation of the desired product. For authenticative purposes a small amount of the alkene intermediate $\mathbf{E}$ was purified to allow full characterization.

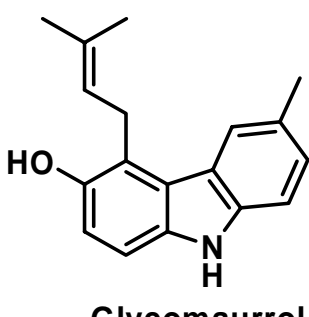

Carbazole 14 (217 mg, $0.546 \mathrm{mmol})$ was dissolved in EtOAc (10 ml). IBX (459 mg, $1.639 \mathrm{mmol}$ ) was added and the reaction heated to reflux for 90 minutes, after which TLC showed complete consumption of the starting material. The reaction was filtered through a sintered glass funnel to remove the excess IBX and its byproducts, washing with EtOAc. The solvent was removed under reduced pressure to produce crude aldehyde intermediate $\mathbf{D}$ Glycomaurrol (231 mg) as a yellow-brown sticky solid. The crude aldehyde intermediate D was then subjected to Wittig conditions without further purification and the procedure is described below. A slurry of isopropyltriphenyl-phosphonium iodide (1.180 g, $2.730 \mathrm{mmol})$ in THF $(10 \mathrm{ml})$ was cooled to $\mathrm{O}{ }^{\circ} \mathrm{C}$. $\mathrm{nBuLi}(0.97 \mathrm{ml}$ of $2.5 \mathrm{M}$ solution in hexanes, $2.425 \mathrm{mmol})$ was added dropwise and the solution allowed to stir for 15 minutes producing a dark orange-red solution. The crude aldehyde intermediate $\mathbf{D}(231 \mathrm{mg})$ was then transferred dropwise to the ylide solution in THF (2 ml). To ensure complete transfer the flask containing the aldehyde was washed twice more with THF $(2+2 \mathrm{ml})$ and the contents added to the ylide solution. After 75 minutes TLC showed complete consumption of the starting material and water was added to quench the reaction. The reaction was poured into water and extracted 3 times with ethyl acetate. The combined organics were washed with water then brine, and dried with $\mathrm{MgSO}_{4}$. The solvent was removed under reduced pressure to produce crude alkene intermediate $\mathbf{E}$ (511 mg). The crude alkene intermediate $\mathbf{E}$ was then subjected to TBAF for removal of the TIPS group and greater ease of isolation and the procedure is described. Crude alkene intermediate $\mathbf{E}$ (511 mg) was dissolved in THF (10 ml). TBAF (1.09 ml of 1.0 M solution in THF, $1.090 \mathrm{mmol})$ was added dropwise and the solution stirred for 10 minutes, after which TLC showed complete consumption of the starting material. Water $(5 \mathrm{ml})$ was added to quench the reaction. The reaction was poured into water and extracted 3 times with ethyl acetate. The combined organics were washed with water then brine, and dried with $\mathrm{MgSO}_{4}$. The solvent was removed under reduced pressure to give a crude mixture that was purified by column chromatography on silica gel (ethyl acetate / hexanes as eluent) to yield Glycomaurrol (125 mg, $0.471 \mathrm{mmol}, 86 \%$ over three steps) as a pale yellow solid. The spectroscopic data for synthetic glycomaurrol is in full agreement with literature ${ }^{5,6}$, with the exception of the carbon signal at $18.2 \mathrm{ppm}$ which was reported to appear at 29.7 ppm: m.p. $=148-150{ }^{0} \mathrm{C} ; \mathrm{R}_{\mathrm{f}}=0.42,33 \%$ ethyl acetate in hexanes; ${ }^{1} \mathrm{H}-\mathrm{NMR}(600 \mathrm{MHz}$, $\mathrm{CDCl}_{3}$ ): $\delta=7.93$ (s, 1H), 7.83 (br.s, $1 \mathrm{H}$ ), 7.31 (d, J = 8.4 Hz, 1H), 7.22 (dd, J = 8.4, 1.2 Hz, 1H), 7.15 (d, J = 8.4 Hz, 1H), 6.96 (d, J = 8.4 Hz, 1H), 5.42-5.39 (m, 1H), 4.82 (s, 1H), 4.00 (d, J = 7.2 $\mathrm{Hz}, 2 \mathrm{H}), 2.52$ (s, 3H), 1.95 (s, 3H), 1.77 (d, J = 1.2 Hz, 3H); ${ }^{13} \mathrm{C}$ NMR (100 MHz, $\left.\mathrm{CDCl}_{3}\right) \delta=$ 147.1, 138.6, 135.1, 134.4, 128.1, 126.6, 123.6, 122.5, 122.1, 121.6, 121.2, 115.2, 110.2, 108.6, 26.3, 25.8, 21.6, 18.2; IR (thin film): 3408, 3227, 3101, 2994, 2967, 2922, 2863, 1590, 1512, 
1477, 1445, 1392, 1342, 1309, 1283, 1267, 1227, 1213, 1167, 1149, 1101, 1071, 1030, 955, 850; HRMS calc'd for $\mathrm{C}_{18} \mathrm{H}_{19} \mathrm{NO}=265.1467$, found $=265.1472$.

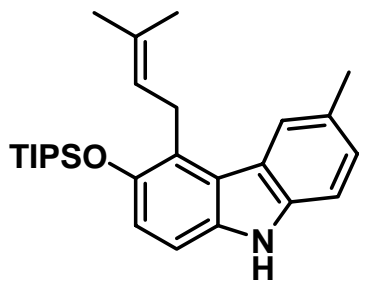

Intermediate E

Pale yellow solid: m.p. $=74-77{ }^{0} \mathrm{C} ; \mathrm{R}_{\mathrm{f}}=0.80$, $33 \%$ ethyl acetate in hexanes; ${ }^{1} \mathrm{H}-\mathrm{NMR}\left(400 \mathrm{MHz}, \mathrm{CDCl}_{3}\right): \delta=7.88$ (s, $\left.1 \mathrm{H}\right), 7.77$ ( br.s, $1 \mathrm{H}$ ), 7.28 (d, J = 8.2 Hz, 1H), 7.21 (dd, J = 8.2, $1.2 \mathrm{~Hz}, 1 \mathrm{H}), 7.09$ (d, J = 8.8 Hz, $1 \mathrm{H}), 6.96$ (d, J = 8.8 Hz, 1H), 5.30-5.25 (m, 1H), 3.98 (d, J = $6 \mathrm{~Hz}, 2 \mathrm{H})$, 2.52 (s, 3H), 1.92 (s, 3H), 1.70 (d, J = 1.2 Hz, 3H), 1.36 (sept, J = 7.6 Hz, 3H), 1.14 (d, J = 7.6 Hz, 18H); ${ }^{13} \mathrm{C}$ NMR (100 MHz, $\left.\mathrm{CDCl}_{3}\right) \delta=146.7$, 138.6, 135.0, 131.8, 127.9, 126.3, 125.8, 123.8, 123.1, 123.0, 122.6, 117.3, 109.9, 107.9, 26.1, 25.5, 21.6, 18.5, 18.1, 13.2; IR (thin film): 3414, 3029, 2964, 2945, 2926, 2896, 2868, 2729, 1584, 1496, 1465, 1443, 1384, 1325, 1291, 1264, 1226, 1172, 1149, 1080, 999, 971, 905, 884, 822, 801, 717, 684, 647; HRMS calc'd for $\mathrm{C}_{27} \mathrm{H}_{39} \mathrm{NOSi}=421.2801$, found $=421.2804$.

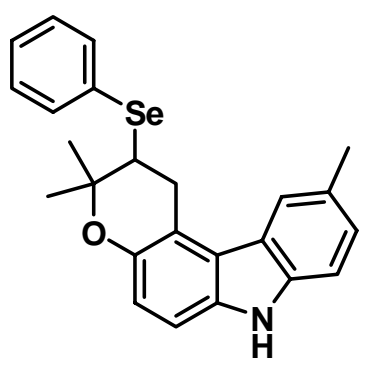

Intermediate F

Gylcomaurrol (31 mg, $0.117 \mathrm{mmol}$ ) was dissolved in DCM (4 ml) and cooled to $-40{ }^{\circ} \mathrm{C}$. $\mathrm{PhSeCl}(24 \mathrm{mg}, 0.125 \mathrm{mmol}$ ) was then added and the solution stirred for 45 minutes after which TLC showed complete consumption of the starting material. The reaction was allowed to warm to room temperature and the solvent removed under reduced pressure. The crude product was purified by column chromatography on silica gel (ethyl acetate / hexanes as eluent) to yield selenide intermediate $\mathbf{F}$ ( $0.40 \mathrm{~g}$, 0.0951 mmol, $82 \%$ ) as an off-white solid: m.p. $=152-155{ }^{0} \mathrm{C} ; \mathrm{R}_{\mathrm{f}}=0.53$, $25 \%$ ethyl acetate in hexanes; ${ }^{1} \mathrm{H}-\mathrm{NMR}\left(600 \mathrm{MHz}, \mathrm{CDCl}_{3}\right): \delta=7.82$ (br.s, 1H), 7.72-7.71 (m, 2H), 7.61 (s,1H), 7.36-7.32 (m, 3H), 7.29 (d, J = 8.4 Hz, 1H), 7.20 (d, J $=8.4 \mathrm{~Hz}, 1 \mathrm{H}), 7.17(\mathrm{~d}, \mathrm{~J}=8.4 \mathrm{~Hz}, 1 \mathrm{H}), 6.91(\mathrm{~d}, \mathrm{~J}=8.4 \mathrm{~Hz}, 1 \mathrm{H}), 3.76$ (dd, J = 6, $10.5 \mathrm{~Hz}, 1 \mathrm{H}$ ), 3.64 (dd, J = 6.0, 16.8 Hz, 1H), 3.40 (dd, J = 10.5, 16.8 Hz, 1H), 2.50 (s, 3H), 1.59 (s, 3H), 1.46 (s, 3H); ${ }^{13} \mathrm{C}$ NMR (100 MHz, $\left.\mathrm{CDCl}_{3}\right) \delta=146.3,138.4,135.4,134.3,129.2,129.1,128.1,128.0$, 126.5, 123.7, 122.2, 120.7, 116.1, 115.2, 110.2, 109.6, 77.2, 47.1, 30.8, 28.3, 21.5, 21.2; IR (thin film): 3409, 3053, 2976, 2926, 2858, 1560, 1499, 1476, 1445, 1383, 1368, 1331, 1311, 1279, 1253, 1216, 1160, 1123, 1085, 1022, 1000, 957, 876, 802, 741, 693, 668; HRMS calc’d for $\mathrm{C}_{24} \mathrm{H}_{23} \mathrm{NOSe}=421.0945$, found $=421.0955$.

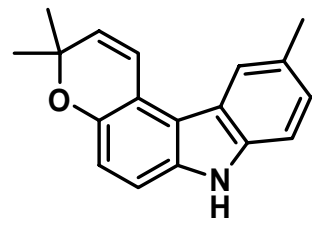

Eustifoline A

Selenide intermediate $\mathbf{F}$ (36 mg, $0.0856 \mathrm{mmol}$ ) was dissolved in DCM (4 ml) and cooled to $0{ }^{\circ} \mathrm{C} . \mathrm{H}_{2} \mathrm{O}_{2}(0.2 \mathrm{ml}$ of $30 \%$ solution in water $)$ was then added and the solution stirred for 30 minutes after which TLC (multiple elutions) showed complete consumption of the starting material. The reaction was diluted with water and the reaction mixture extracted with DCM 3 times. The combined organics were washed with brine and dried with $\mathrm{MgSO}_{4}$. The solvent was removed under reduced pressure to give a crude solid that was purified by column chromatography on silica gel (ethyl acetate / hexanes as eluent) to yield Eustifoline A (14 mg, $0.0532 \mathrm{mmol}, 61 \%$ ) as a pale yellow solid. The spectroscopic data for synthetic Eustifoline A is in full agreement with literature ${ }^{4,5}$ : m.p. $=184-187{ }^{0} \mathrm{C} ; \mathrm{R}_{\mathrm{f}}=0.54,25 \%$ ethyl acetate in hexanes; ${ }^{1} \mathrm{H}-\mathrm{NMR}\left(400 \mathrm{MHz}, \mathrm{CDCl}_{3}\right.$ ): $\delta=7.92$ (s, 1H), 7.76 ( br.s, 1H), 7.29 (d, J = 9.6 Hz, 1H), 7.28 (d, 
$\mathrm{J}=8.0 \mathrm{~Hz}, 1 \mathrm{H}), 7.20$ (d, J = 8.0 Hz, 1H), 7.14 (d, J = $8.8 \mathrm{~Hz}, 1 \mathrm{H}), 6.92(\mathrm{~d}, \mathrm{~J}=8.8 \mathrm{~Hz}, 1 \mathrm{H}), 5.83$ (d, J = 9.6 Hz, 1H), 2.53 (s, 3H), $1.50(\mathrm{~s}, 6 \mathrm{H}) ;{ }^{13} \mathrm{C}$ NMR (100 MHz, $\left.\mathrm{CDCl}_{3}\right) \delta=146.4,138.8$, 135.1, 131.3, 128.3, 126.8, 123.4, 122.2, 120.2, 118.5, 115.6, 115.3, 110.4, 75.1, 27.2, 21.5 (note: $1 \mathrm{sp}^{2}$ carbon signal is missing presumably due to overlap. However, this is in agreement with literature $^{5}$ ); IR (thin film): 3397, 3050, 2968, 2921, 2854, 1593, 1494, 1441, 1433, 1358, 1330, 1302, 1287, 1259, 1207, 1196, 1164, 1145, 1119, 1086, 967, 935, 890, 871, 810, 748, 719; HRMS calc'd for $\mathrm{C}_{18} \mathrm{H}_{17} \mathrm{NO}=263.1310$, found $=263.1305$.

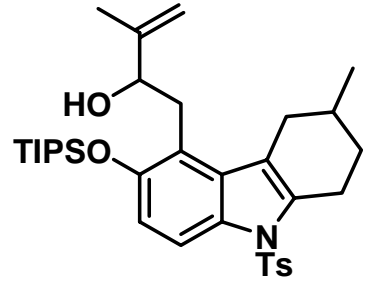

Intermediate G

Aldehyde 13 (1.010 g, $1.824 \mathrm{mmol})$ was dissolved in THF (25 ml) and cooled to $-78{ }^{\circ} \mathrm{C}$. Isopropenylmagesium bromide $(7.29 \mathrm{ml}$ of $0.5 \mathrm{M}$ solution in THF, $3.645 \mathrm{mmol}$ ) was added and the solution stirred for 15 minutes after which TLC indicated a small amount of stating material remained. Isopropenylmagesium bromide $(1.82 \mathrm{ml}$ of $0.5 \mathrm{M}$ solution in THF, $0.910 \mathrm{mmol}$ ) was added and the solution stirred for an additional 15 minutes after which TLC still indicated a small amount of starting material remained. After an additional 15 minutes water was then added to quench the excess isopropenylmagnesium bromide and the solution allowed to warm to room temperature. The reaction was poured into water and extracted 3 times with ethyl acetate. The combined organics were washed with water then brine, and dried with $\mathrm{MgSO}_{4}$. The solvent was removed under reduced pressure to produce a crude solid that was purified by column chromatography on silica gel (ethyl acetate / hexanes as eluent) to yield alcohol intermediate $\mathbf{G}$ ( $0.989 \mathrm{~g}, 1.660 \mathrm{mmol}, 91$ $\%)$ as a white foam and mixture of diasteriomers: $\mathrm{R}_{\mathrm{f}}=0.51,20 \%$ ethyl acetate in hexanes; ${ }^{1} \mathrm{H}$ $\operatorname{NMR}\left(600 \mathrm{MHz}, \mathrm{CDCl}_{3}\right): \delta=7.95,7.94(2 \mathrm{~d}, \mathrm{~J}=9.0 \mathrm{~Hz}, 1 \mathrm{H}), 7.613,7.610(2 \mathrm{~d}, \mathrm{~J}=8.1 \mathrm{~Hz}, 2 \mathrm{H})$, 7.19, 7.18 (2d, J = 8.1 Hz, 2H), 6.80 (d, J = 9.0 Hz, 1H), $5.06(\mathrm{~s}, 1 \mathrm{H}), 4.87$ (s, 1H), 4.33-4.26 (m, $1 \mathrm{H})$, 3.24-3.10 (m, 4H), 2.94-2.82 (m, 1H), 2.80, 2.37 (2br.s, 1H), 2.45-2.40, 2.31-2.24 (2m, 1H), 2.343, 2.349 (2s, 3H), 1.94-1.33 (m, 5H), 1.45-1.31 (m, 4H), 1.16-1.10 (m, 18H), 1.18-1.14 (3H); ${ }^{13} \mathrm{C}$ NMR $\left(100 \mathrm{MHz}, \mathrm{CDCl}_{3}\right) \delta=150.7,150.6,147.6,147.5,144.34,144.31,136.14,136.12$, $136.04,136.01,131.80,131.75,130.7,130.5,129.69,129.66,126.29,126.26,119.9,119.7$, $118.74,118.68,114.6,113.22,113.19,110.84,110.79,77.2,76.3,33.3,33.1,32.8,30.6,30.5$, 29.0, 28.7, 24.8, 24.6, 21.5, 21.4, 21.2, 18.11, 18.07, 18.04, 17.96, 13.2; IR (thin film): 3568, 3097, 2948, 2728, 1653, 1598, 1472, 1431, 1369, 1262, 1176, 1092, 1059, 1014, 912, 883, 809, 734, 668, 603, 578, 543; HRMS calc'd for $\mathrm{C}_{34} \mathrm{H}_{49} \mathrm{NO}_{4} \mathrm{SSi}=595.3152$, found $=595.3147$.

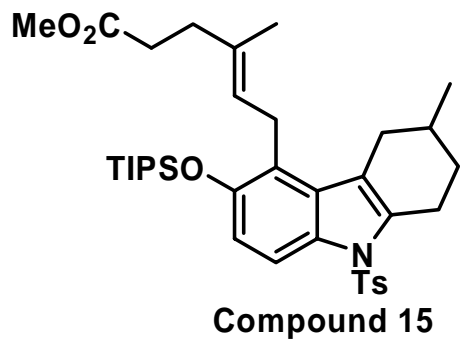

Alcohol intermediate $\mathbf{G}(0.972 \mathrm{~g}, 1.631 \mathrm{mmol})$ and propionic acid $(0.1 \mathrm{ml})$ were dissolved in trimethylorthoacetate $(15 \mathrm{ml})$ and heated at reflux for 32 hours, after which TLC showed complete consumption of starting material. The reaction was then cooled to room temperature (reaction mixture was loaded directly onto column without removal of solvent) and purified by column chromatography on silica gel (ethyl acetate / hexanes as eluent) to yield ester $\mathbf{1 5}$ (1.010 g, 1.549 mmol, $95 \%$ ) as a very pale yellow viscous oil: $R_{\mathrm{f}}=0.46,20 \%$ ethyl acetate in hexanes; ${ }^{1} \mathrm{H}-\mathrm{NMR}\left(600 \mathrm{MHz}, \mathrm{CDCl}_{3}\right): \delta=7.88(\mathrm{~d}, \mathrm{~J}=9.3 \mathrm{~Hz}, 1 \mathrm{H}), 7.61(\mathrm{~d}, \mathrm{~J}=8.1 \mathrm{~Hz}, 2 \mathrm{H})$, 7.16 (d, J = 8.1 Hz, 2H), 7.76 (d, J = 9.3 Hz, 1H), 5.12 (t, J = 4.8 Hz, 1H), 3.64-3.56 (m, 2H), 3.54 (s, 3H), 3.14 (br.d, J = 18.0 Hz, 1H), 2.90-2.82 (m, 2H), 2.38-2.26 (m, 8H), 1.93-1.87 (m, 
1H), 1.82-1.74 (m, 1H), 1.73 (s, 3H), 1.43- 1.37 (m, 1H), 1.31 (sept, J = 7.8 Hz, 3H), 1.10 (dd, J = 7.8, $1.2 \mathrm{~Hz}, 18 \mathrm{H}), 1.05(\mathrm{~d}, \mathrm{~J}=6.6 \mathrm{~Hz}, 3 \mathrm{H}) ;{ }^{13} \mathrm{C}$ NMR $\left(100 \mathrm{MHz}, \mathrm{CDCl}_{3}\right) \delta=173.7,150.1$, 144.1, 136.2, 135.4, 132.2, 131.4, 130.1, 129.5, 126.2, 125.9, 122.7, 119.0, 114.7, 112.4, 51.3, 34.4, 32.9, 32.1, 30.7, 28.8, 25.2, 24.7, 21.4, 21.3, 18.0, 16.4, 13.1; IR (thin film): 2947, 2867, 1740, 1598, 1472, 1433, 1369, 1264, 1201, 1175, 1092, 1039, 1016, 915, 883, 811, 673, 603, 577, 547; HRMS calc’d for $\mathrm{C}_{37} \mathrm{H}_{53} \mathrm{NO}_{5} \mathrm{SSi}=651.3414$, found $=651.3429$.

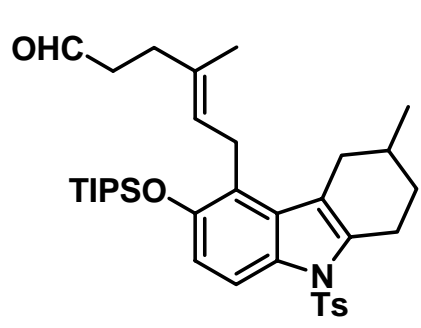

Intermediate $\mathrm{H}$

Ester 15 (0.486 g, $1.342 \mathrm{mmol})$ was dissolved in DCM $(15 \mathrm{ml})$ and cooled to $-78{ }^{\circ} \mathrm{C}$. DIBAL $(2.5 \mathrm{ml}$ of $1.5 \mathrm{M}$ solution in toluene, 3.750 mmol) was added dropwise and the solution stirred for 15 minutes, after which TLC showed complete consumption of the starting material. Methanol $(14 \mathrm{ml})$ was added to quench the excess DIBAL (cautiously at first) and the mixture was stirred at $-78{ }^{\circ} \mathrm{C}$ for 20 minutes, and then at room temperature for 40 minutes. The reaction was poured into $5 \% \mathrm{HCl}$ solution and extracted 4 times with ethyl acetate. The combined organics were washed with $5 \% \mathrm{HCl}$ solution then water then brine, and dried with $\mathrm{MgSO}_{4}$. The solvent was removed under reduced pressure to produce a crude oil that was purified by column chromatography on silica gel (ethyl acetate / hexanes as eluent) to yield aldehyde intermediate $\mathbf{H}(0.432 \mathrm{~g}, 0.695 \mathrm{mmol}, 93 \%)$ as a gummy colourless oil: $\mathrm{R}_{\mathrm{f}}=0.45,20$ \% ethyl acetate in hexanes; ${ }^{1} \mathrm{H}-\mathrm{NMR}\left(400 \mathrm{MHz}, \mathrm{CDCl}_{3}\right): \delta=9.70$ (s, 1H), 7.86 ( d, J = 9.2 Hz, 1H), 7.61 (d, J = 8.0 Hz, 2H), 7.17 (d, J = 8.0 Hz, 1H), 6.74 (d, J = 9.2 Hz, 1H), 5.15-5.10 (m, 1H), 3.64-3.52 (m, 2H), 3.12 (br.d, J = $18.0 \mathrm{~Hz}, 1 \mathrm{H}), 2.90-2.79(\mathrm{~m}, 2 \mathrm{H}), 2.46$ (t, J = $7.6 \mathrm{~Hz}, 2 \mathrm{H}$ ), 2.35-2.24 (m, 6H), 1.83-1.72 (m, 1H), 1.72 (s, 3H), 1.44-1.24 (m, 4H), 1.09 (d, J = 7.2 Hz, 18H), $1.04(\mathrm{~d}, \mathrm{~J}=6.8 \mathrm{~Hz}, 3 \mathrm{H}) ;{ }^{13} \mathrm{C}$ NMR $\left(100 \mathrm{MHz}, \mathrm{CDCl}_{3}\right) \delta=202.3,150.1,144.2,136.1,135.5$, 132.0, 131.3, 130.0, 129.6, 126.3, 126.1, 122.6, 118.9, 114.7, 112.5, 42.1, 32.2, 31.6, 30.7, 28.8, 25.2, 24.7, 21.5, 21.4, 18.1, 16.5, 13.1; IR (thin film): 3428, 2944, 2865, 2718, 1725, 1597, 1468, 1431, 1368, 1263, 1173, 1152, 1134, 1091, 1037, 1016, 961, 915, 883, 810, 671, 601, 574, 547; HRMS calc'd for $\mathrm{C}_{36} \mathrm{H}_{51} \mathrm{NO}_{4} \mathrm{SSi}=621.3308$, found $=621.3286$.

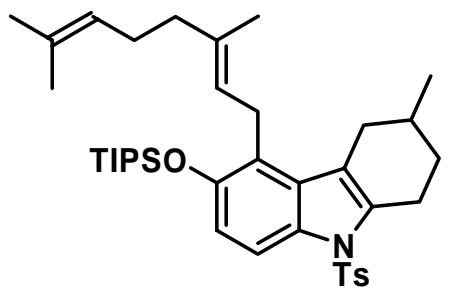

Compound 16

A slurry of isopropyltriphenyl-phosphonium iodide (1.153 g, 2.667 $\mathrm{mmol})$ in THF $(10 \mathrm{ml})$ was cooled to $\mathrm{O}^{\circ} \mathrm{C}$. nBuLi $(1.58 \mathrm{ml}$ of $1.6 \mathrm{M}$ solution in hexanes, $2.528 \mathrm{mmol}$ ) was added dropwise and the solution allowed to stir for 10 minutes producing a dark orange-red solution. Aldehyde intermediate $\mathbf{H}$ (425 $\mathrm{mg}, 0.667 \mathrm{mmol})$ was then transferred dropwise to the ylide solution in THF $(3 \mathrm{ml})$. To ensure complete transfer the flask containing the aldehyde was washed twice more with THF (2 ml) and the contents added to the ylide solution. After 15 minutes TLC showed complete consumption of the starting material and water was added to quench the reaction. The reaction was poured into water and extracted 3 times with ethyl acetate. The combined organics were washed with water then brine, and dried with $\mathrm{MgSO}_{4}$. The solvent was removed under reduced pressure to produce a crude mixture that was purified by column chromatography on silica gel (dichloromethane / hexanes as eluent) to yield alkene $\mathbf{1 6}$ (363 mg, $0.560 \mathrm{mmol}, 84 \%$ ) as a light yellow viscous oil: $\mathrm{R}_{\mathrm{f}}=0.52,10 \%$ ethyl acetate in hexanes; ${ }^{1} \mathrm{H}-\mathrm{NMR}\left(400 \mathrm{MHz}, \mathrm{CDCl}_{3}\right): \delta=7.90$ (d, J = $\left.8.8 \mathrm{~Hz}, 1 \mathrm{H}\right), 7.63(\mathrm{~d}, \mathrm{~J}=8.4 \mathrm{~Hz}, 2 \mathrm{H}$ ), 
7.17 (d, J = 8.4 Hz, 2H), 6.77 (d, J = 8.8 Hz, 1H), 5.13-5.06 (m, 2H), 3.67-3.56 (m, 2H), 3.16 (br.d J = 17.6 Hz, 1H), 2.97-2.83 (m, 2H), 2.49-2.33 (m, 4H), 2.09-2.02 (m, 2H), 2.00-1.88 (m, 3H), 1.85-1.75 (m, 1H), 1.73 (s, 3H), 1.64 (s, 3H), 1.57 (s, 3H), 1.48-1.27(m, 4H), 1.13 (d, J = 7.2 $\mathrm{Hz}, 18 \mathrm{H}), 1.06$ (d, J = $6.8 \mathrm{~Hz}, 3 \mathrm{H}) ;{ }^{13} \mathrm{C} \mathrm{NMR}\left(100 \mathrm{MHz}, \mathrm{CDCl}_{3}\right) \delta=150.1,144.1,136.2,135.3$, 133.9, 131.4, 131.2, 130.2, 129.6, 126.3, 125.0, 124.3, 123.2, 119.2, 114.8, 112.3, 39.4, 32.2, 30.7, 28.9, 26.7, 25.6, 25.3, 24.7, 21.44, 21.36, 18.1, 17.6, 16.5, 13.1; IR (thin film): 2946, 2928, 2868, 1598, 1473, 1432, 1370, 1264, 1175, 1092, 1039, 1014, 915, 883, 810, 668; HRMS calc'd for $\mathrm{C}_{39} \mathrm{H}_{57} \mathrm{NO}_{3} \mathrm{SSi}=647.3828$, found $=647.3822$.

Carbazole 17 was prepared in two steps from alkene $\mathbf{1 6}$ without full characterization of the intermediate as the detosylated tetrahydrocarbazole was not stable to column chromatography.

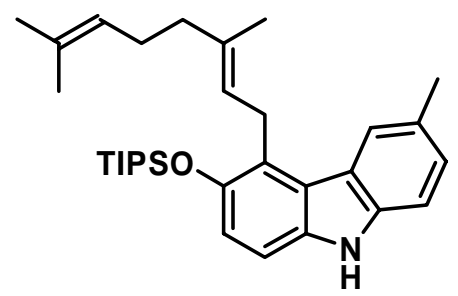

Compound 17

Alkene 16 (56 mg, $0.0864 \mathrm{mmol}$ ) was dissolved in a mixture of $\mathrm{MeOH}$ (5 ml) and THF (5 ml). Magnesium (63 mg, $2.592 \mathrm{mmol}$ ) and $\mathrm{NH}_{4} \mathrm{Cl}(9 \mathrm{mg}, 0.168 \mathrm{mmol}$ ) were added and the mixture allowed to stir for 6 hours, after which TLC showed complete consumption of the starting material. The reaction was poured into saturated $\mathrm{NH}_{4} \mathrm{Cl}$ solution and extracted 3 times with ethyl acetate. The combined organics were washed three times with water, once with brine, and dried with $\mathrm{MgSO}_{4}$. The solvent was removed under reduced pressure to produce crude detosylated tethrahydrocarbazole (43 $\mathrm{mg}$ ) as a yellow oil. The resulting crude detosylated tethrahydrocarbazole was divided into two equivalent portions ( $22 \mathrm{mg}$ each) for the aromatization reaction. The procedure will be given for one of the two portions. The crude detosylated tethrahydrocarbazole was dissolved in dioxane (2 ml). DDQ (20 mg, $0.0881 \mathrm{mmol}$ ) was dissolved in dioxane $(1 \mathrm{ml})$ and added dropwise to the detosylated tethrahydrocarbazole solution. This addition was continued until a green colour change no longer occurred upon further addition of the DDQ solution. At this point TLC showed that all starting material had been consumed and the reaction was diluted with EtOAc. The reaction was poured into saturated $\mathrm{NaHCO}_{3}$ solution and extracted 3 times with EtOAc. The combined organics were washed 3 times with saturated $\mathrm{NaHCO}_{3}$ solution, once with brine, and dried with $\mathrm{MgSO}_{4}$. The solvent was removed under reduced pressure to produce the crude carbazole which was purified by column chromatography on silica gel (EtOAc / hexanes as eluent) to yield carbazole 17 (9 $\mathrm{mg}$ from both portions, $0.0184 \mathrm{mmol}, 21 \%$ over two steps) as an off white solid: $\mathrm{R}_{\mathrm{f}}=0.63,20 \%$ ethyl acetate in hexanes; ${ }^{1} \mathrm{H}-\mathrm{NMR}\left(600 \mathrm{MHz}, \mathrm{CDCl}_{3}\right): \delta=7.85$ (s, 1H), 7.78 (br.s, $\left.1 \mathrm{H}\right), 7.28$ (d, J = 7.8 Hz, 1H), 7.19 (dd, J = 7.8, 1.2 Hz, 1H), 7.09 (d, J = 8.7 Hz, 1H), 6.95 (d, J = 8.7 Hz, 1H), 5.28 (dt, $J=$ 5.4, $1.2 \mathrm{~Hz}, 1 \mathrm{H}), 5.07-5.04(\mathrm{~m}, 1 \mathrm{H}), 3.97$ (d, J = 5.4 Hz, 2H), 2.49 (s, 3H), 2.08-2.04 (m, 2H), 2.02-1.98 (m, 2H), 1.91 (s, 3H), 1.59 (s, 3H), 1.53 (s, 3H), 1.34 (sept, J = $7.8 \mathrm{~Hz}, 3 \mathrm{H}), 1.13$ (d, J = $7.8 \mathrm{~Hz}, 18 \mathrm{H}) ;{ }^{13} \mathrm{C}$ NMR $\left(100 \mathrm{MHz}, \mathrm{CDCl}_{3}\right) \delta=146.7,138.7,135.6,135.1,131.2,127.9,126.4$, 125.9, 124.4, 123.9, 123.3, 123.2, 122.8, 117.3, 109.9, 107.8, 39.6, 26.9, 26.0, 25.6, 21.6, 18.2, 17.6, 16.7, 13.2; IR (thin film):3411, 3024, 2962, 2943, 2925, 2866, 2728, 1584, 1495, 1464, 1442, 1383, 1324, 1290, 1263, 1224, 1149, 1072, 1036, 1015, 999, 971, 907, 883, 825, 801, 716, 680; HRMS calc'd for $\mathrm{C}_{32} \mathrm{H}_{47} \mathrm{NOSi}=489.3427$, found $=489.3434$. 


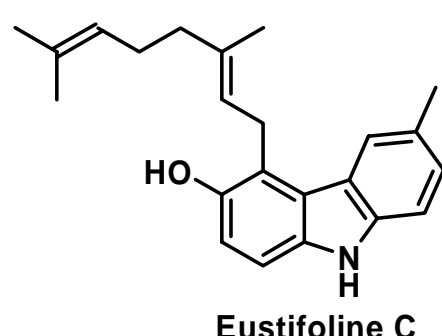

Eustifoline C

Carbazole 17 (16 mg, $0.0327 \mathrm{mmol}$ ) was dissolved in THF (4 ml). TBAF $(0.065 \mathrm{ml}$ of $1.0 \mathrm{M}$ solution in THF, $0.0650 \mathrm{mmol})$ was added dropwise and the solution stirred for 5 minutes, after which TLC showed complete consumption of the starting material. Water $(2 \mathrm{ml})$ was added to quench the reaction. The reaction was poured into water and extracted 3 times with ethyl acetate. The combined organics were washed with water then brine, and dried with $\mathrm{MgSO}_{4}$.

The solvent was removed under reduced pressure to produce a crude mixture that was purified by column chromatography on silica gel (ethyl acetate / hexanes as eluent) to yield Eustifoline C (7 mg, $0.0210 \mathrm{mmol}, 64 \%$ ) as an off-white solid. The spectroscopic data for synthetic Eustifoline $C$ is in full agreement with literature ${ }^{4}: R_{f}=0.41,30 \%$ ethyl acetate in hexanes; ${ }^{1} \mathrm{H}-\mathrm{NMR}\left(400 \mathrm{MHz}, \mathrm{CDCl}_{3}\right): \delta=7.93(\mathrm{~d}, \mathrm{~J}=0.8 \mathrm{~Hz}, 1 \mathrm{H}), 7.83$ (br.s, $\left.1 \mathrm{H}\right), 7.30$ (d, J $=8.8 \mathrm{~Hz}, 1 \mathrm{H}), 7.21$ (br.d, $\mathrm{J}=8.8 \mathrm{~Hz}, 1 \mathrm{H}), 7.15(\mathrm{~d}, \mathrm{~J}=8.6 \mathrm{~Hz}, 1 \mathrm{H}), 6.96(\mathrm{~d}, \mathrm{~J}=8.6 \mathrm{~Hz}, 1 \mathrm{H}), 5.41$ (t, J = 6.8 Hz, 1H), $5.06(\mathrm{t}, \mathrm{J}=6.2 \mathrm{~Hz}, 1 \mathrm{H}), 4.86(\mathrm{~s}, 1 \mathrm{H}), 4.01(\mathrm{~d}, \mathrm{~J}=6.8 \mathrm{~Hz}, 2 \mathrm{H}), 2.52(\mathrm{~s}, 3 \mathrm{H})$ 2.16-2.04 (m, 4H), 1.94 (s, 3H), $1.64(\mathrm{~s}, 3 \mathrm{H}), 1.57(\mathrm{~s}, 3 \mathrm{H}) ;{ }^{13} \mathrm{C}$ NMR $\left(100 \mathrm{MHz}, \mathrm{CDCl}_{3}\right) \delta=$ 147.4, 138.7, 138.2, 135.1, 131.8, 128.1, 126.6, 123.9, 123.6, 122.6, 122.1, 121.6, 121.2, 115.3, 110.2, 108.7, 39.7, 26.5, 26.3, 25.6, 21.6, 17.7, 16.5; IR (thin film): 3413, 3230, 2968, 2920, 1590, 1512, 1478, 1446, 1396, 13.75, 1310, 1296, 1283, 1268, 1219, 1150, 1088, 1065, 1027, 956, 860, 798, 792; HRMS calc'd for $\mathrm{C}_{23} \mathrm{H}_{27} \mathrm{NO}=333.2093$, found $=333.2093$.

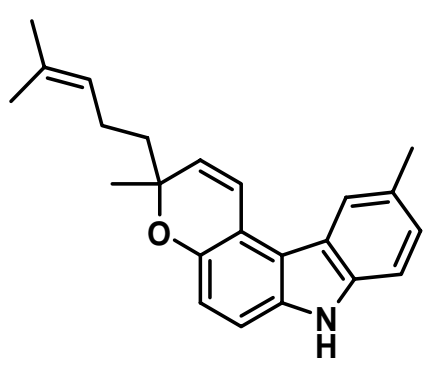

Eustifoline B

The procedure is taken from literature ${ }^{3}$ with modifications made to the stoichiometry and temperature. Eustifoline C (7 mg, $0.0210 \mathrm{mmol})$, benzoquinone (18 mg, $0.167 \mathrm{mmol})$, and $\mathrm{Pd}(\mathrm{OAc}) 2$ (8mg, 0.0356 $\mathrm{mmol}$ ) were dissolved in THF ( $4 \mathrm{ml}$ ) and the reaction was heated at $65{ }^{\circ} \mathrm{C}$ for 90 minutes after which TLC showed complete consumption of the starting material. The reaction was cooled to room temperature and the solvent removed under reduced pressure. The residue was purified by a combination of preparative TLC (ethyl acetate / hexanes as eluent) and column chromatography on silica gel (ethyl acetate / hexanes as eluent) to yield Eustifoline B (4.5 mg, $0.0136 \mathrm{mmol}, 64 \%)$ as a colourless oil. The spectroscopic data for synthetic Eustifoline $B$ is in full agreement with literature ${ }^{4}: R_{f}=0.61,30$ \% ethyl acetate in hexanes; ${ }^{1} \mathrm{H}-\mathrm{NMR}\left(600 \mathrm{MHz}, \mathrm{CDCl}_{3}\right): \delta=7.92$ (s, $\left.1 \mathrm{H}\right), 7.78$ ( br.s, $1 \mathrm{H}$ ), 7.31 (d, J = 9.9 Hz, 1H), 7.29 (d, J = 7.8 Hz, 1H), 7.20 (br.d, J = 7.8 Hz, 1H), 7.14 (d, J = 8.7 Hz, 1H), 6.91 (d, J = 8.7 Hz, 1H), 5.80 (d, J = 9.9 Hz, 1H), 5.11 (t, J = 6.9 Hz, 1H), 2.52 (s, 3H), 2.22-2.14 $(\mathrm{m}, 2 \mathrm{H}), 1.82-1.73(\mathrm{~m}, 2 \mathrm{H}), 1.68(\mathrm{~s}, 3 \mathrm{H}), 1.59(\mathrm{~s}, 3 \mathrm{H}), 1.46(\mathrm{~s}, 3 \mathrm{H}) ;{ }^{13} \mathrm{C}$ NMR $(100 \mathrm{MHz}$, $\left.\mathrm{CDCl}_{3}\right) \delta=146.6,138.8,135.0,131.6,130.5,128.4,126.7,124.3,123.4,122.3,120.6,118.6$, 115.5, 115.2, 110.32, 110.28, 77.2, 40.3, 25.7, 25.4, 22.8, 21.5, 17.6; IR (thin film): 3412, 3044, 2967, 2921, 2857, 1577, 1493, 1443, 1376, 1330, 1301, 1285, 1257, 1203, 1148, 1093, 1026, 957, 865, 803, 749, 722; HRMS calc'd for $\mathrm{C}_{23} \mathrm{H}_{25} \mathrm{NO}=331.1936$, found $=331.1942$.

\section{References:}

1) England, D.B., and Kerr, M.A. J.Org.Chem. 2005, 70, 6519.

2) More, J.D.; Finney, N.S. Org. Lett. 2002, 4, 3001.

3) Koh, J.H., Mascarenhas, C., and Gagne, M.R. Tetrahedron. 2004, 60, 7405.

4) Ito, C.; Furukawa, H. Chem. Pharm. Bull. 1990, 38, 1548. 
5) Kumar, V.; Reisch, J.; Wickramasinghe, A. Aust. J. Chem. 1989, 1375.

6) Forke, R.; Krahl, M. A.; Krause, T.; Schlechtingen, G.; Knölker, H.-J. Synlett. 2007, 2, 268. 


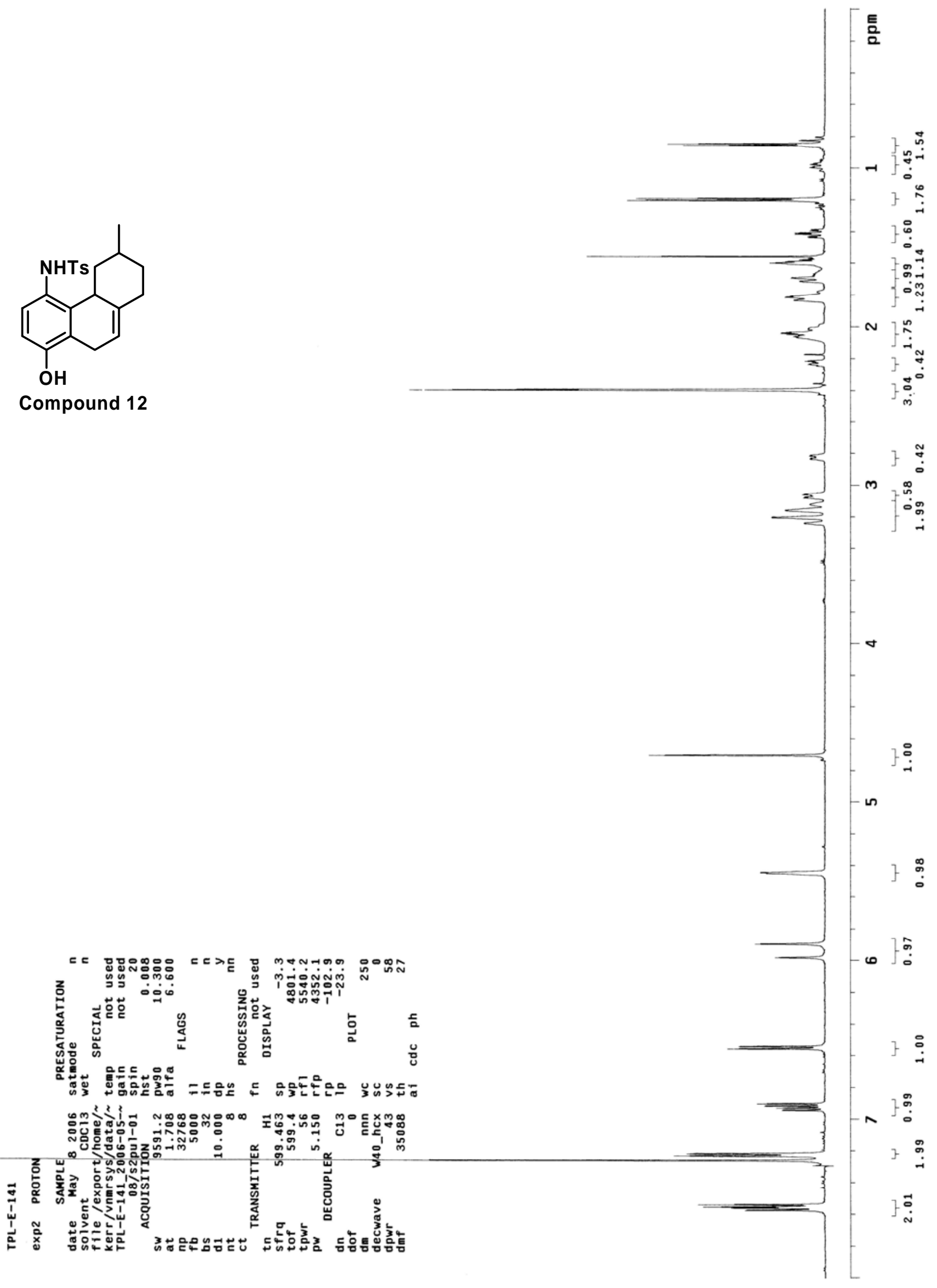




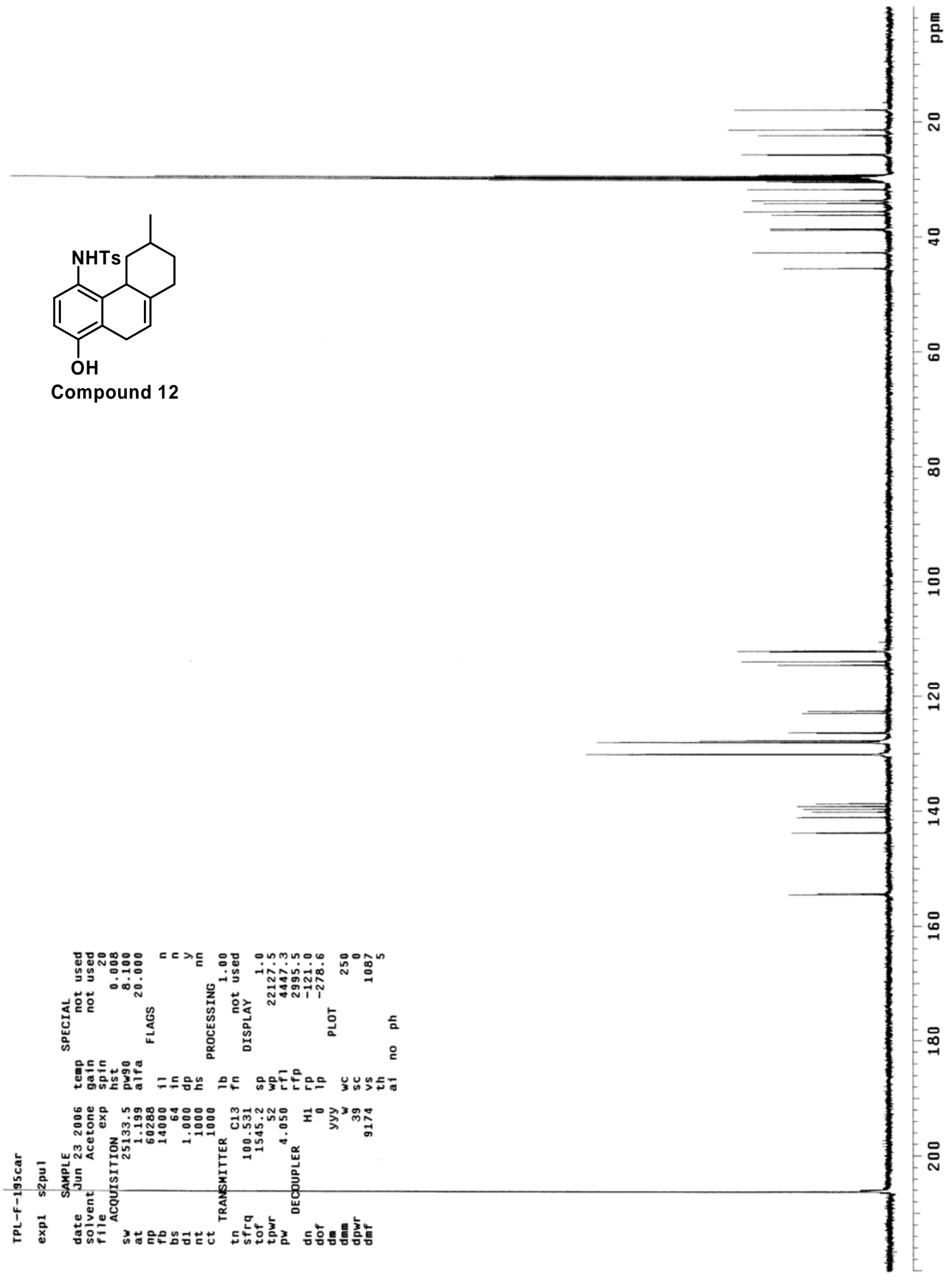




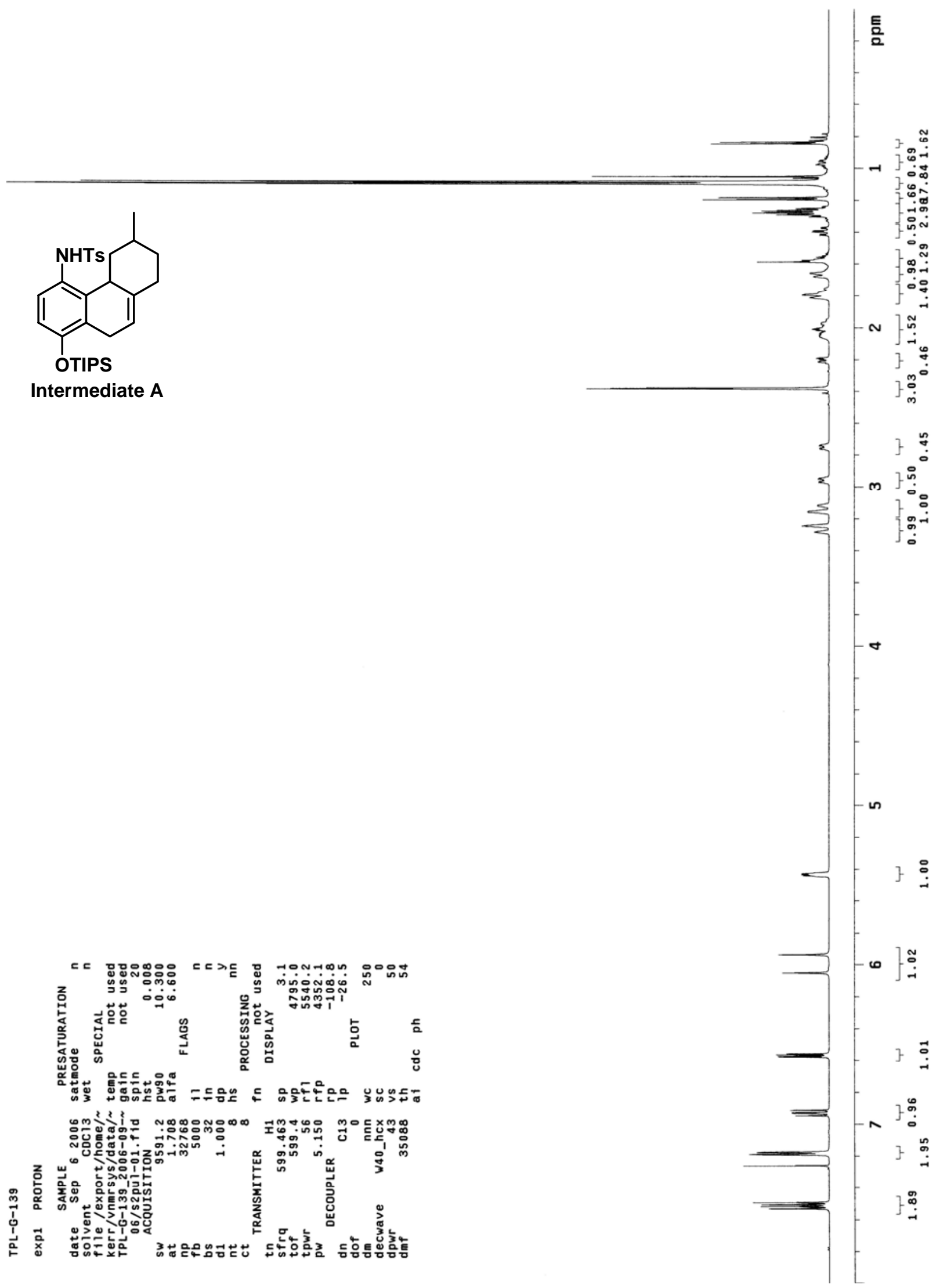




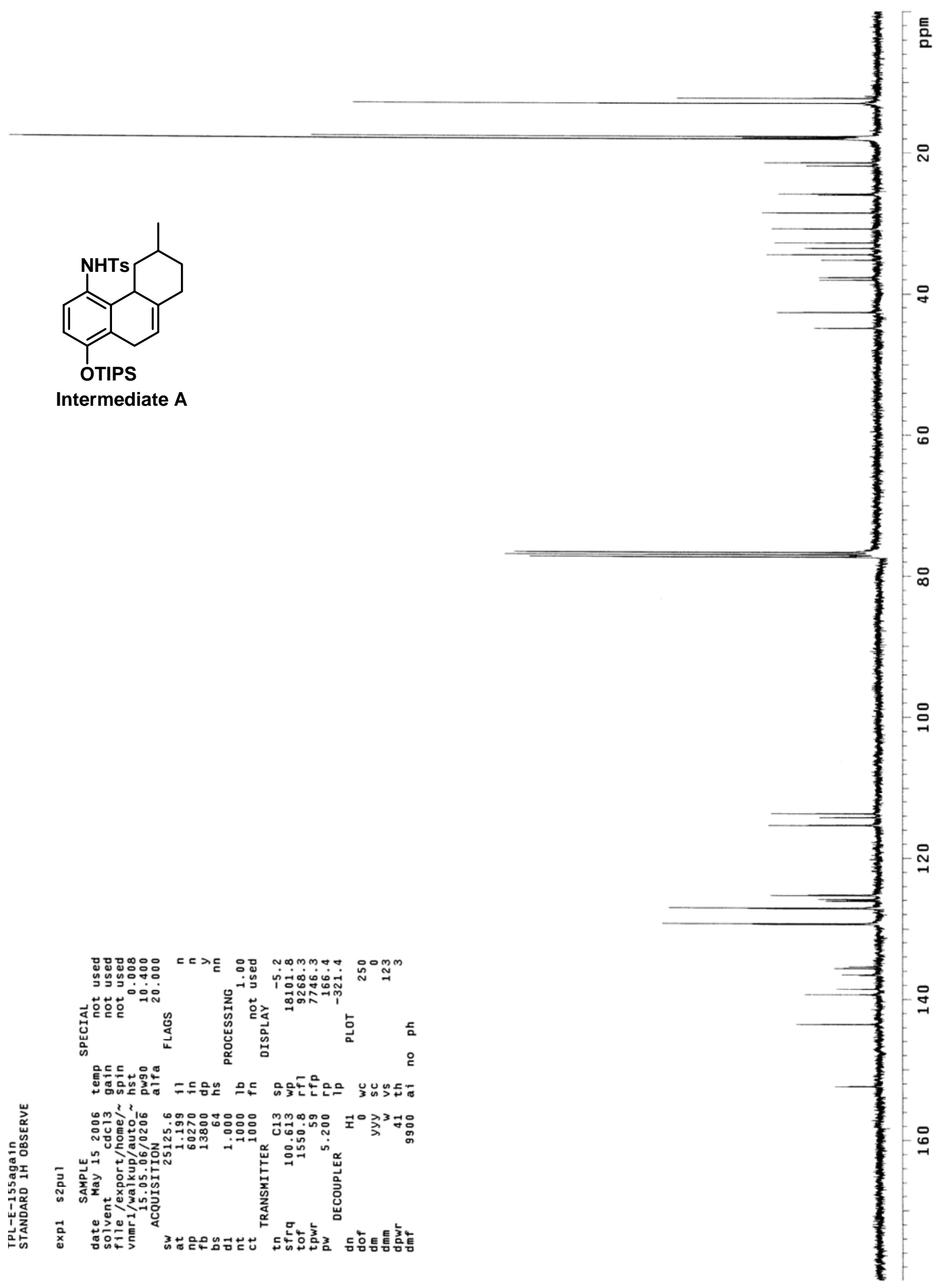




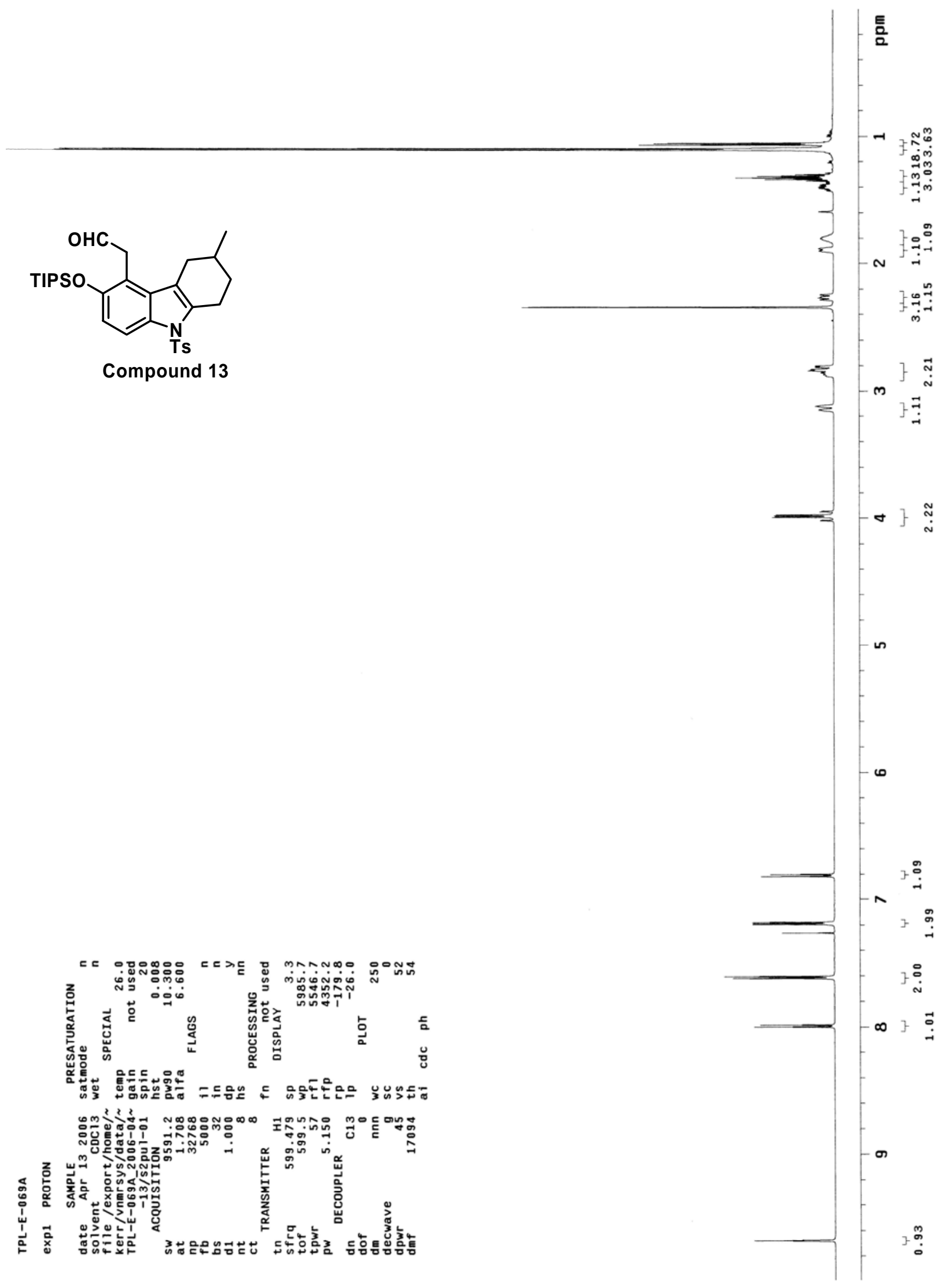




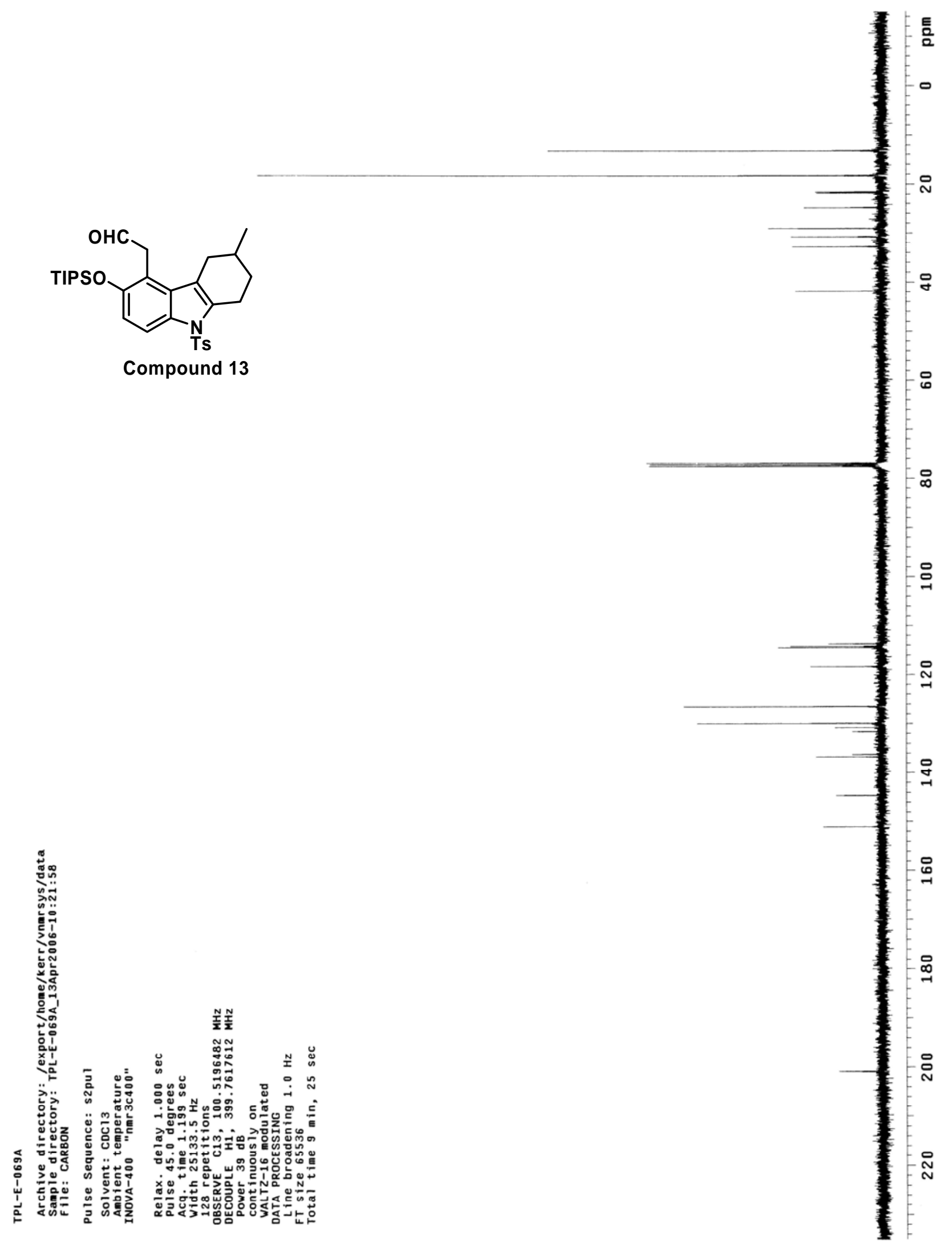




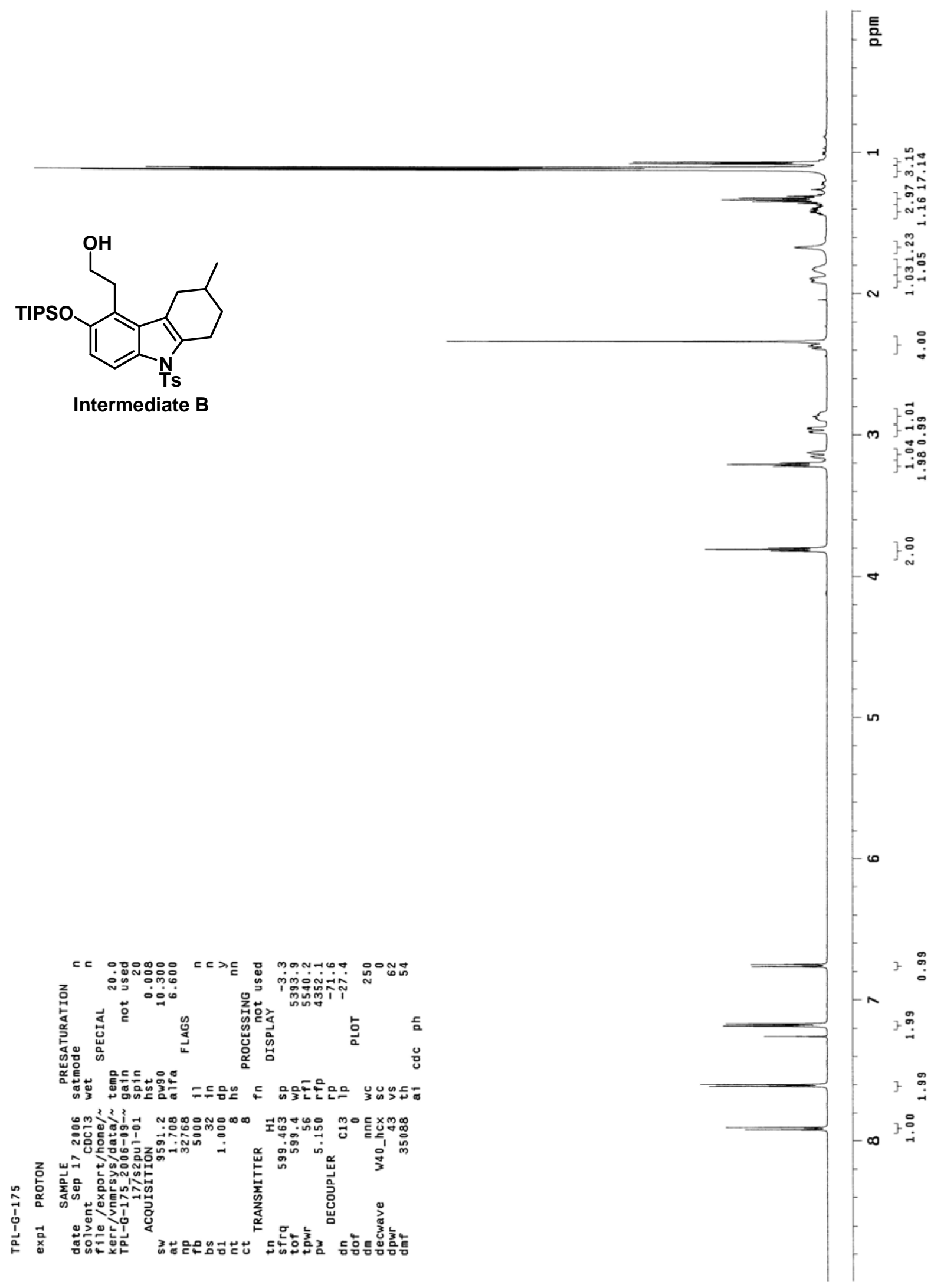




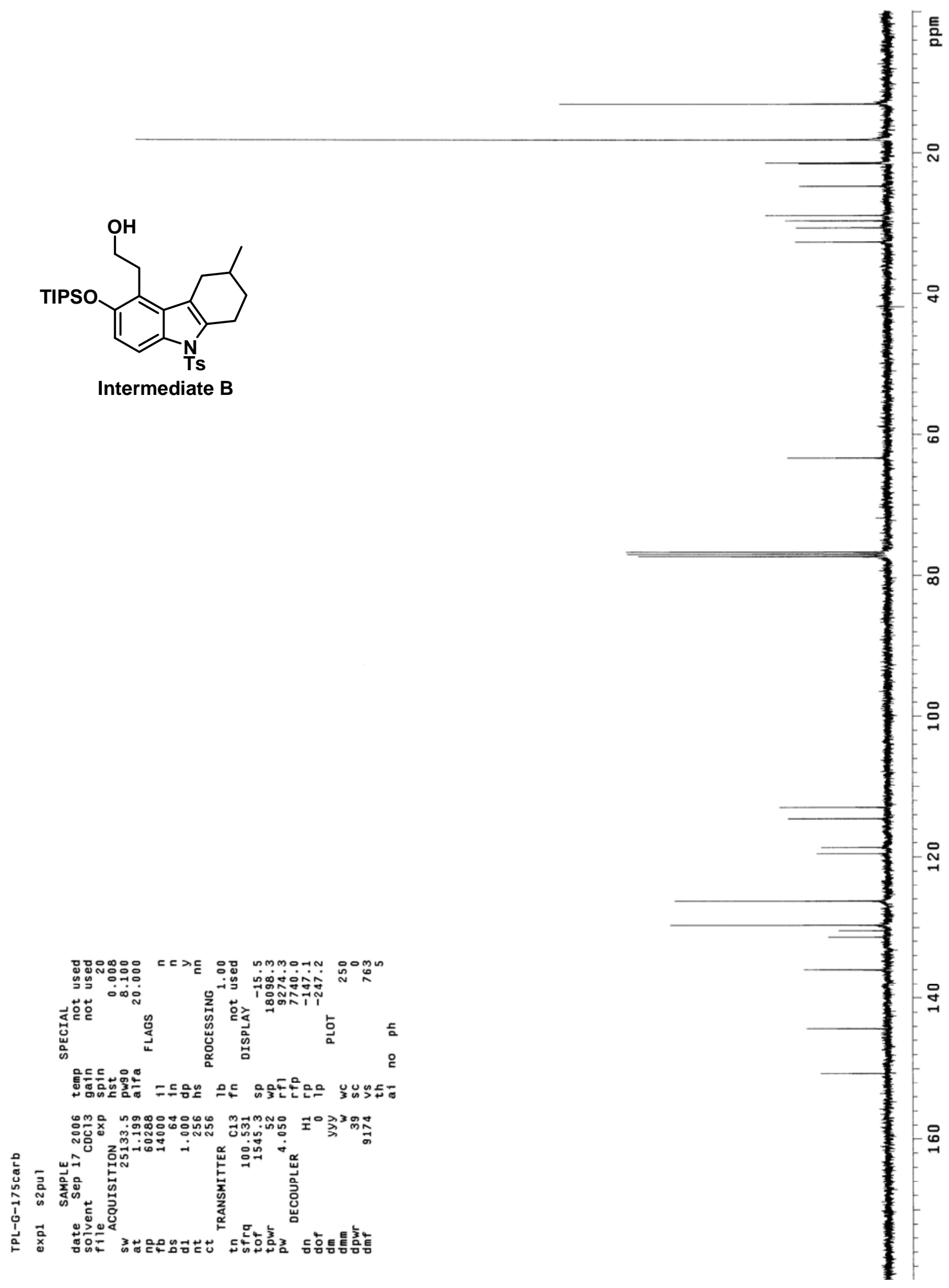




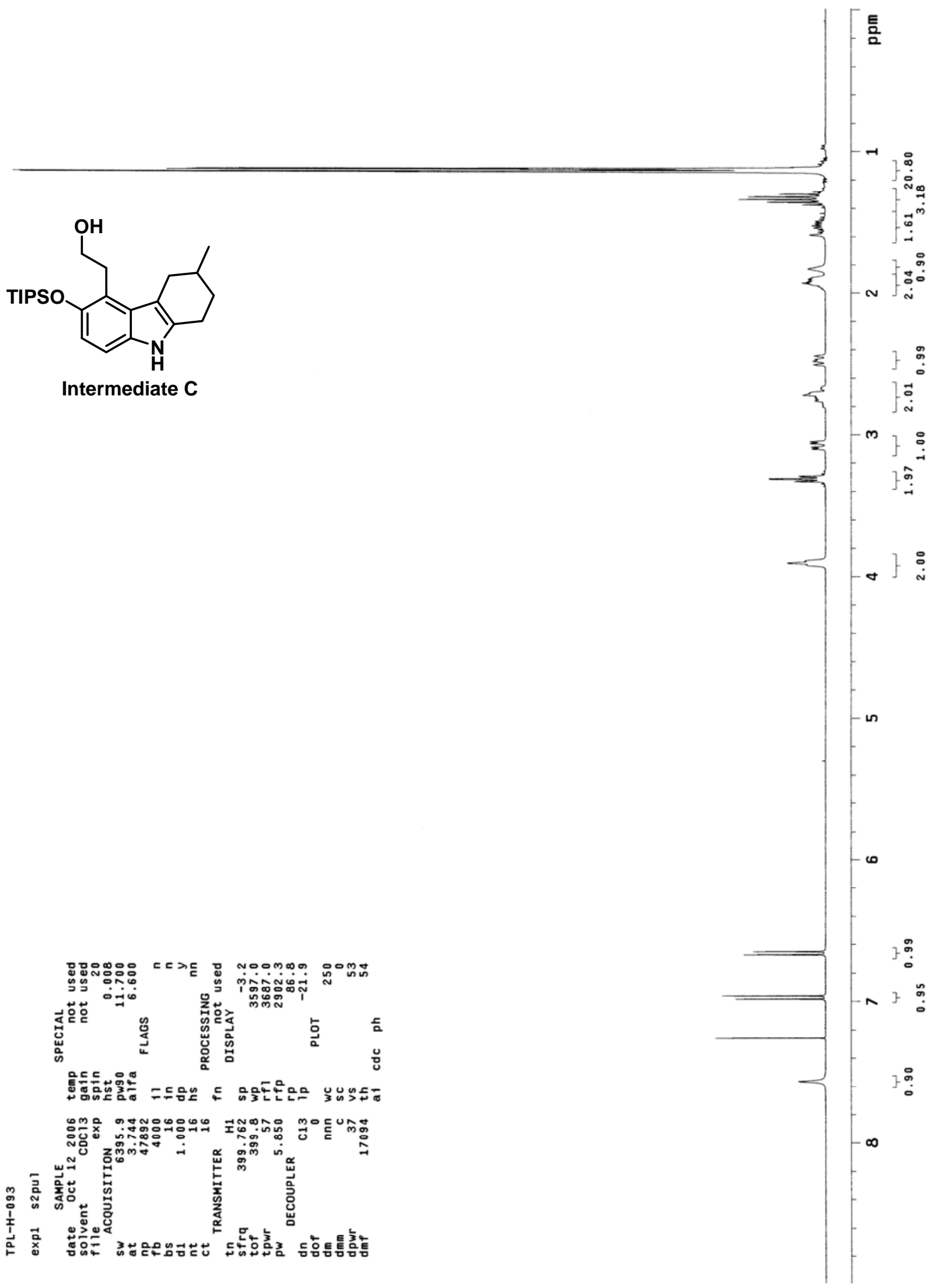



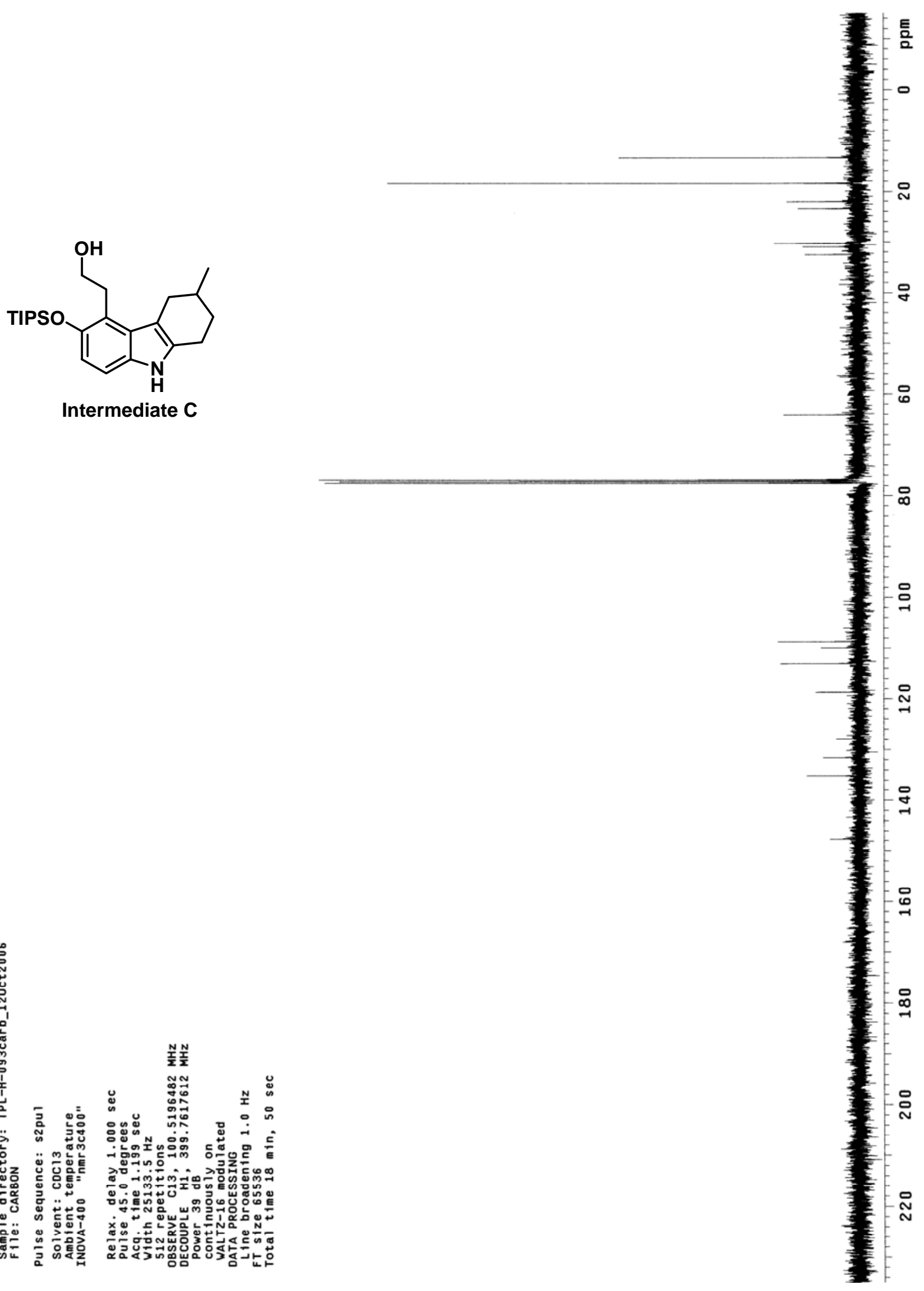


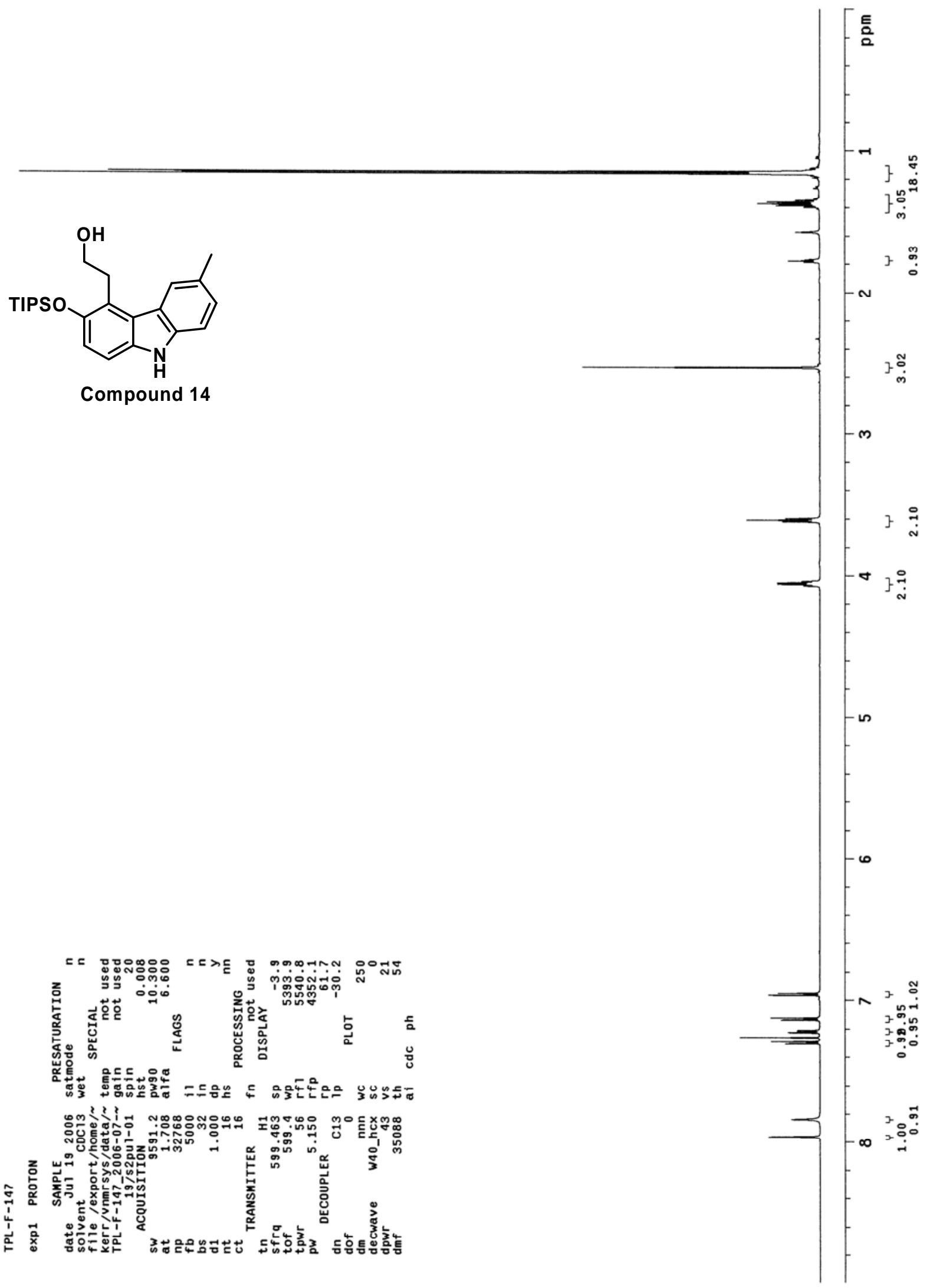




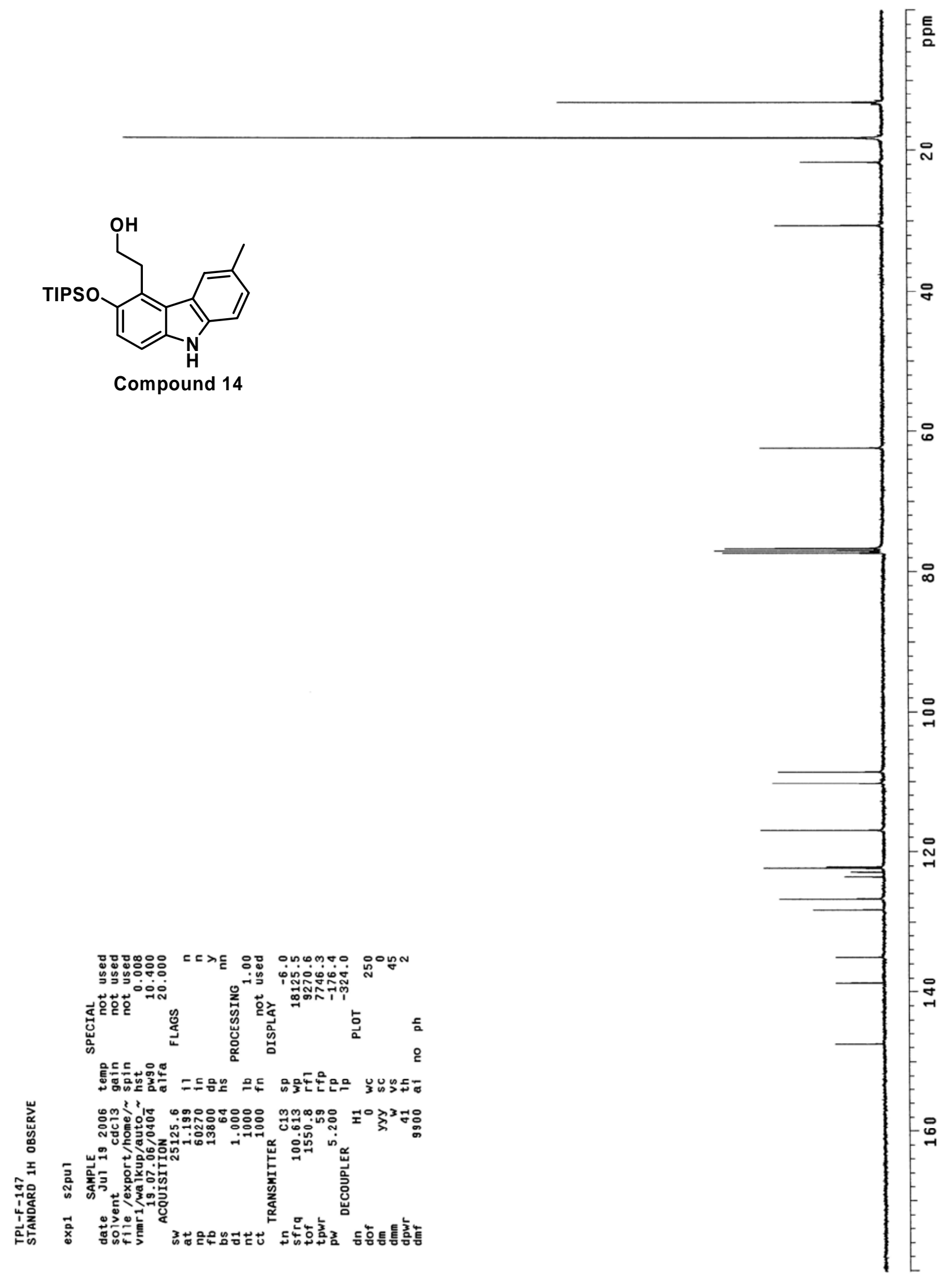




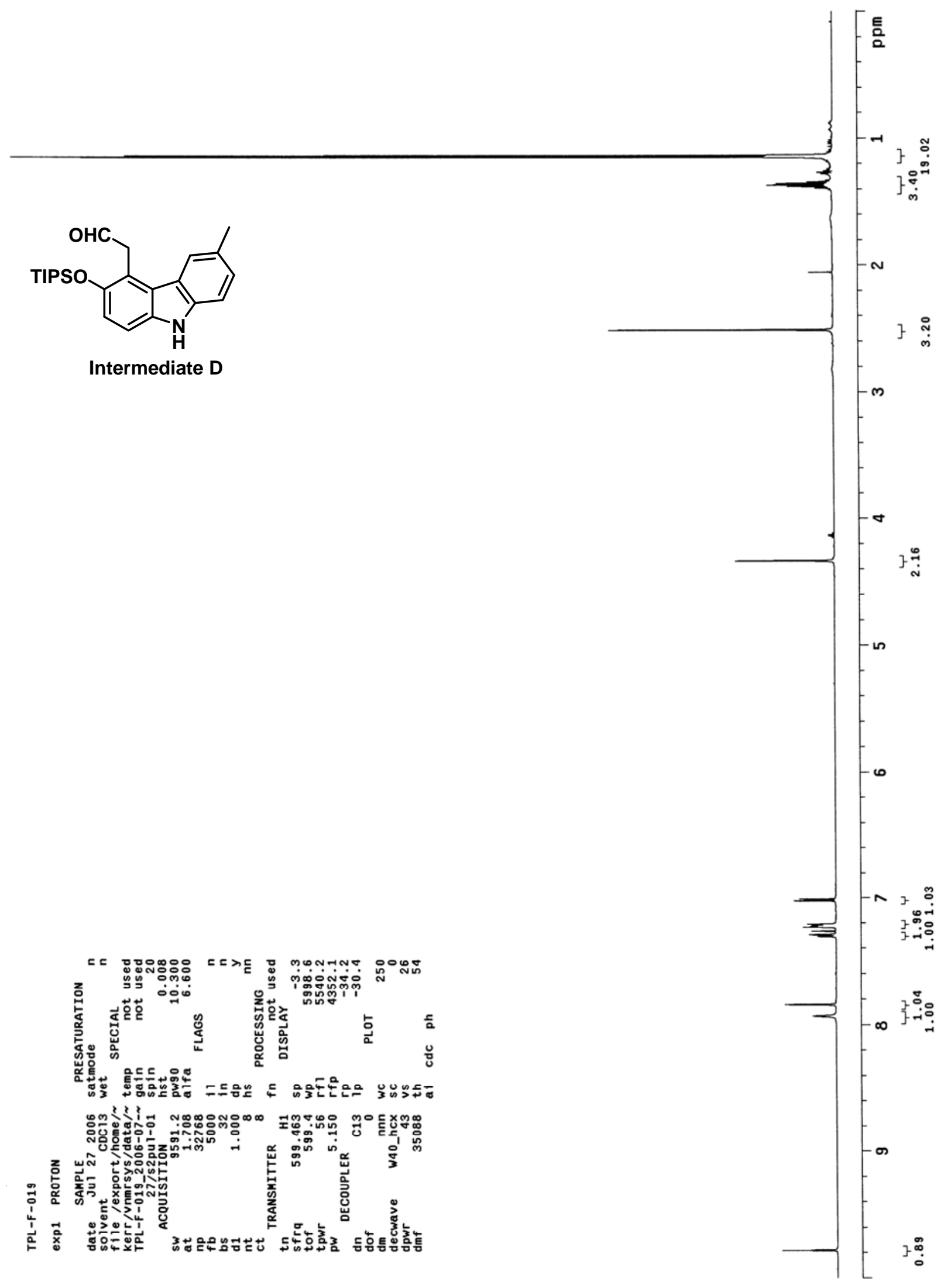




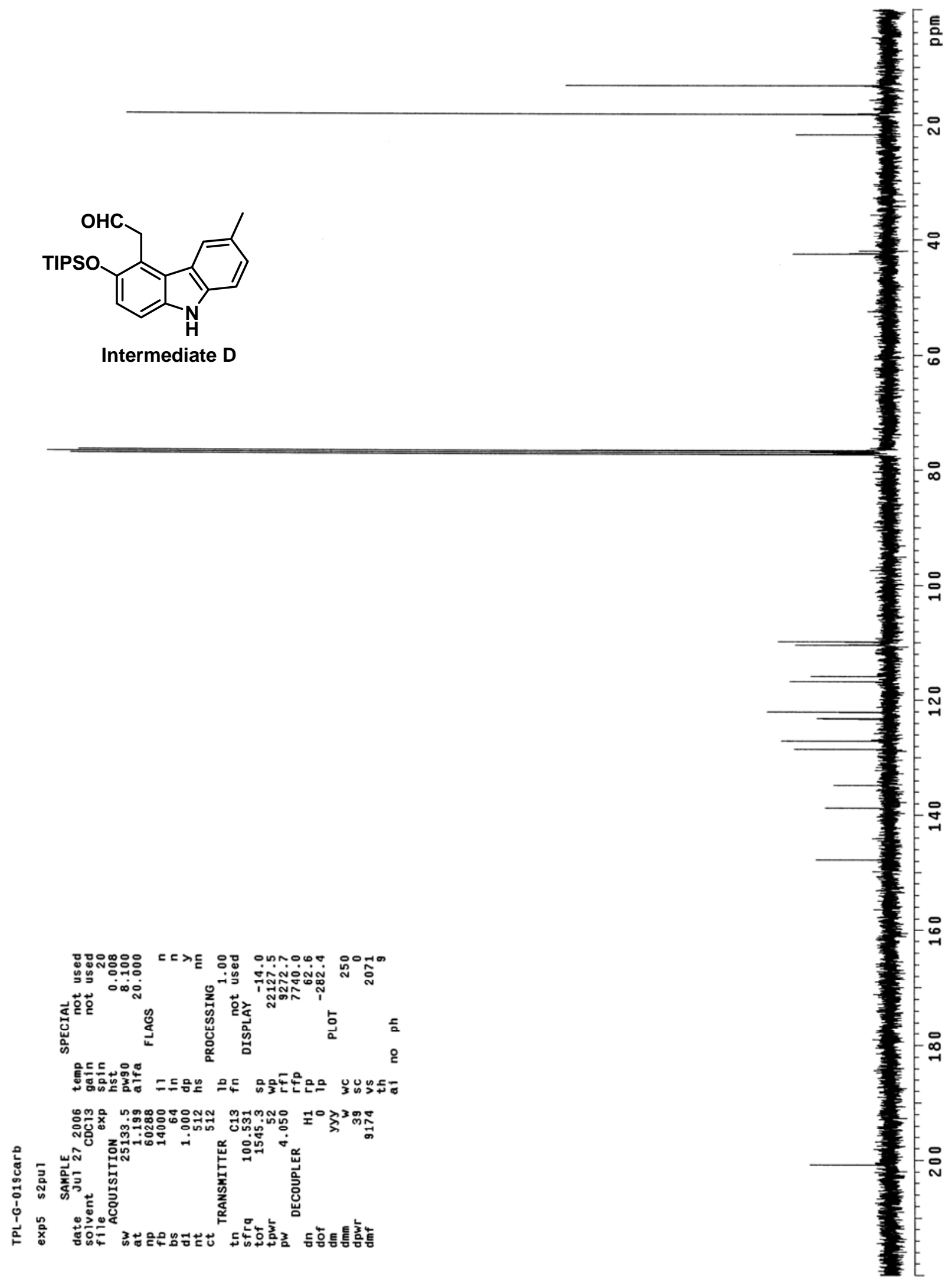




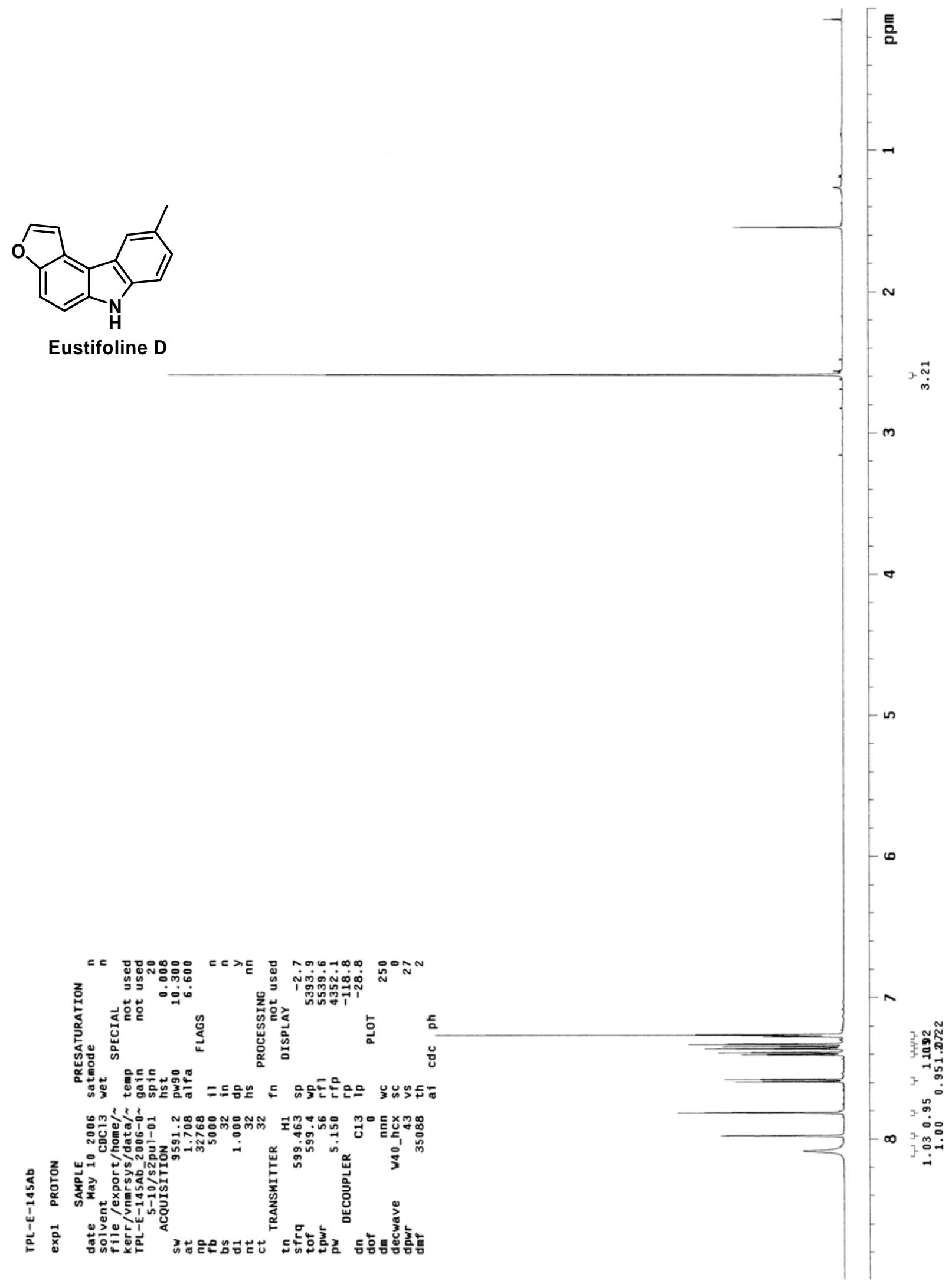




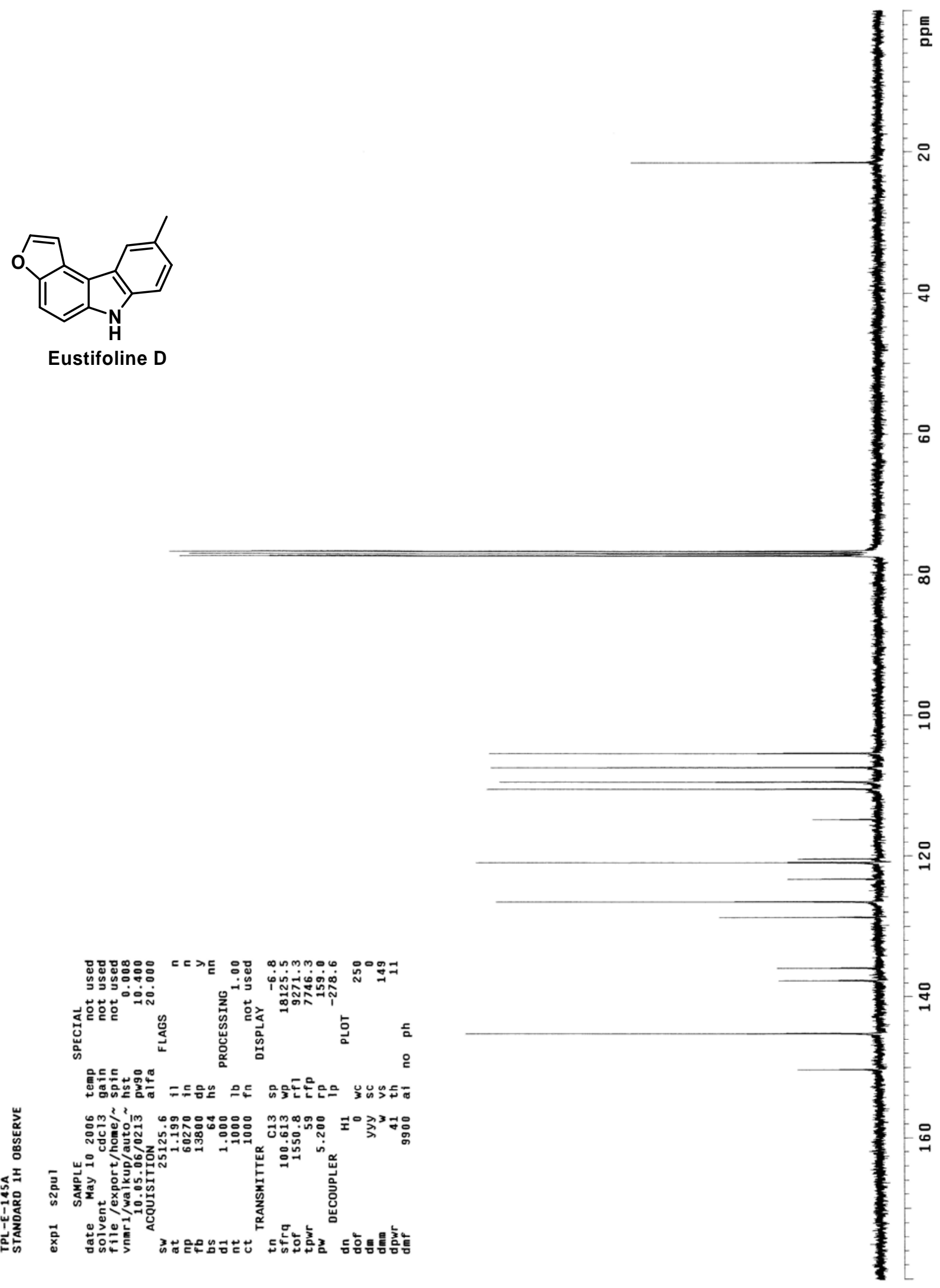




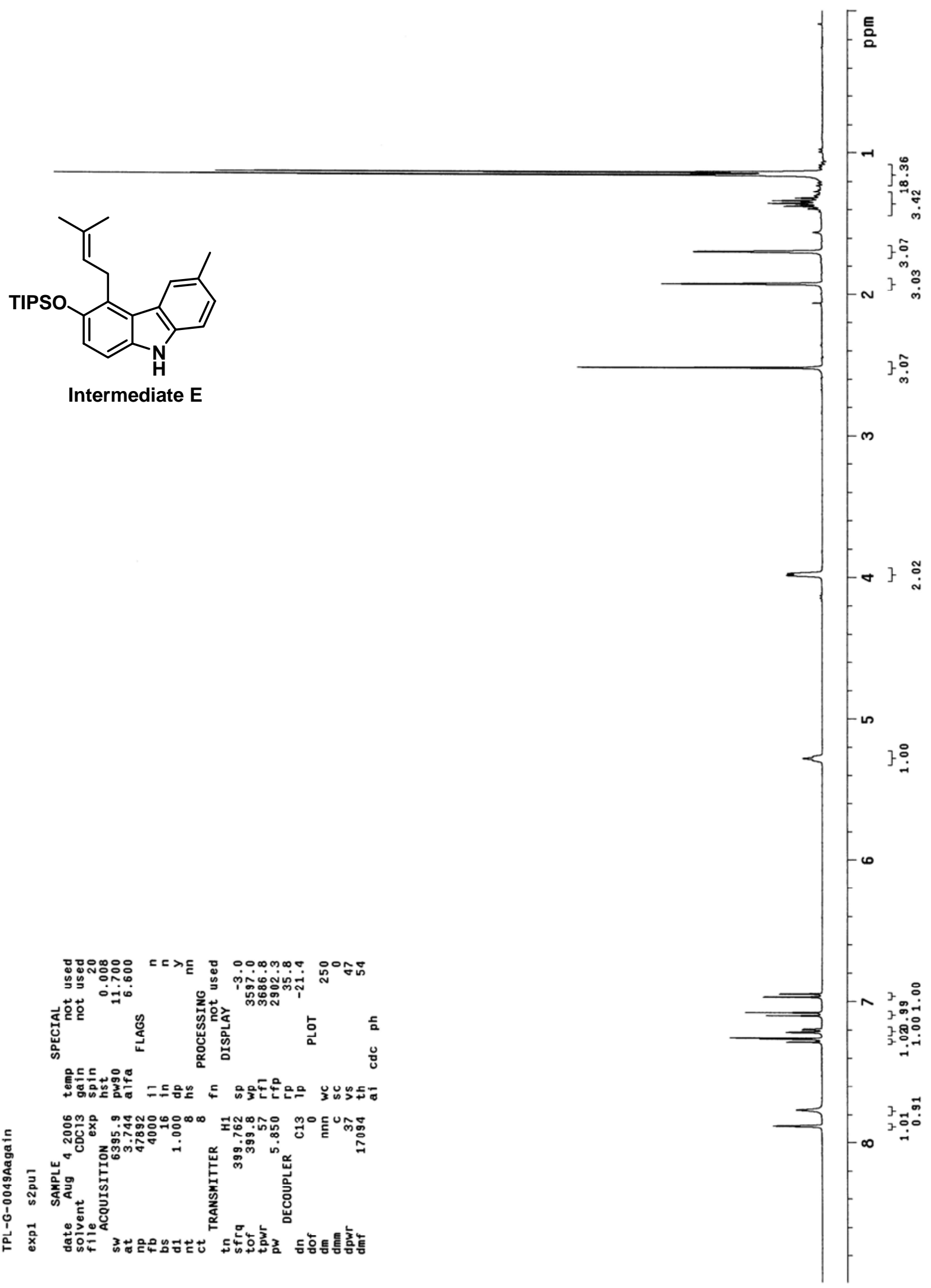




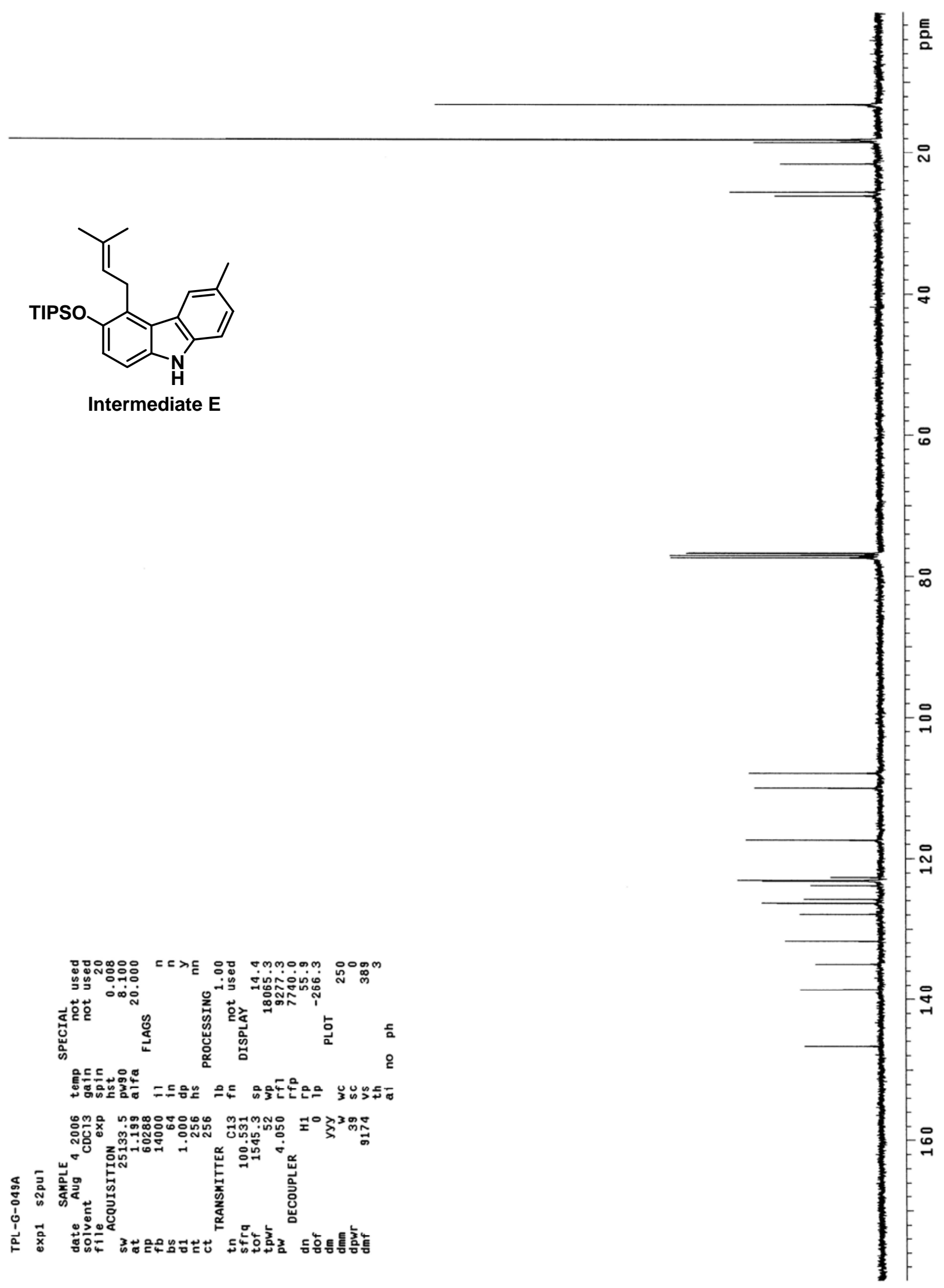




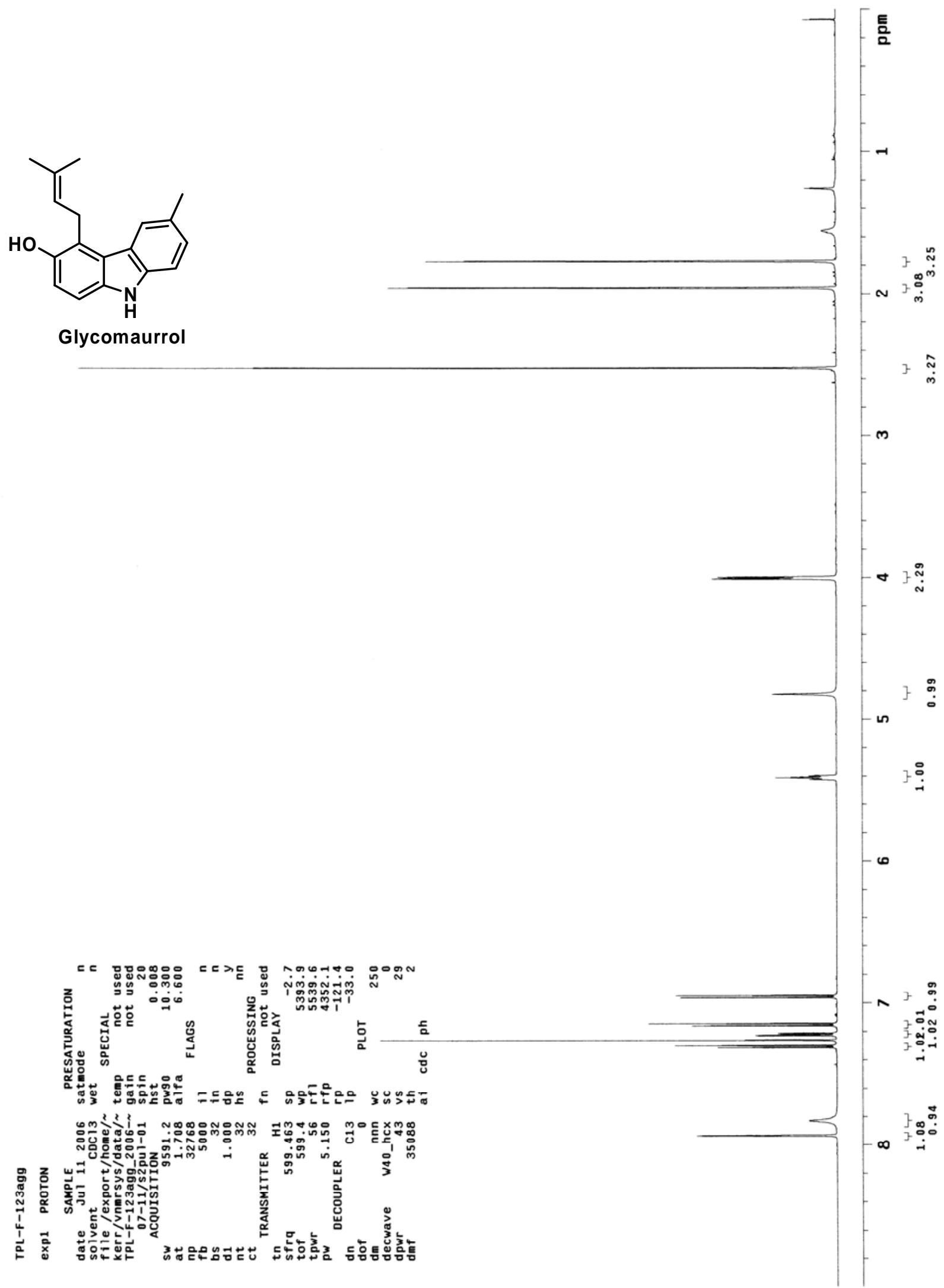




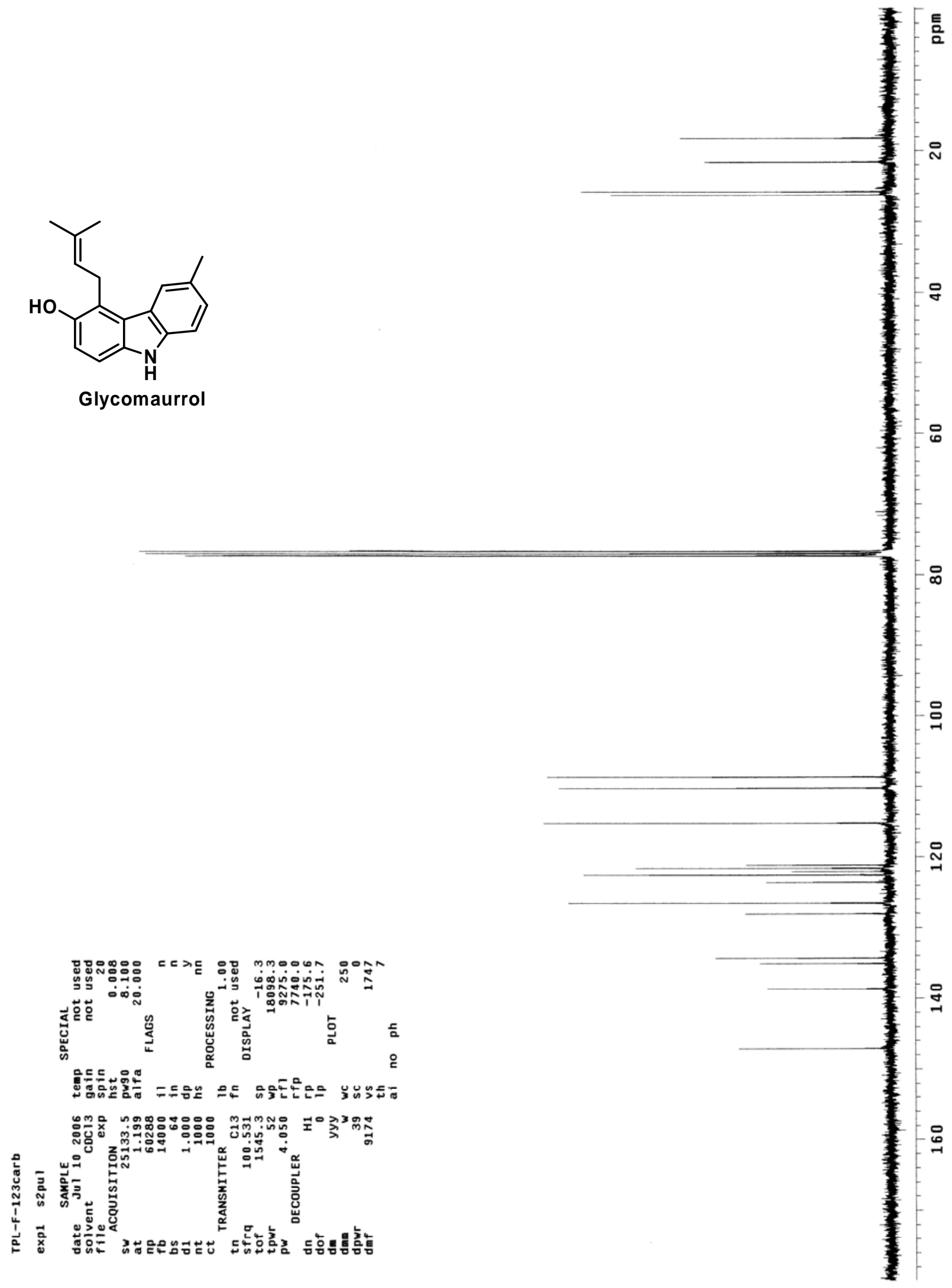




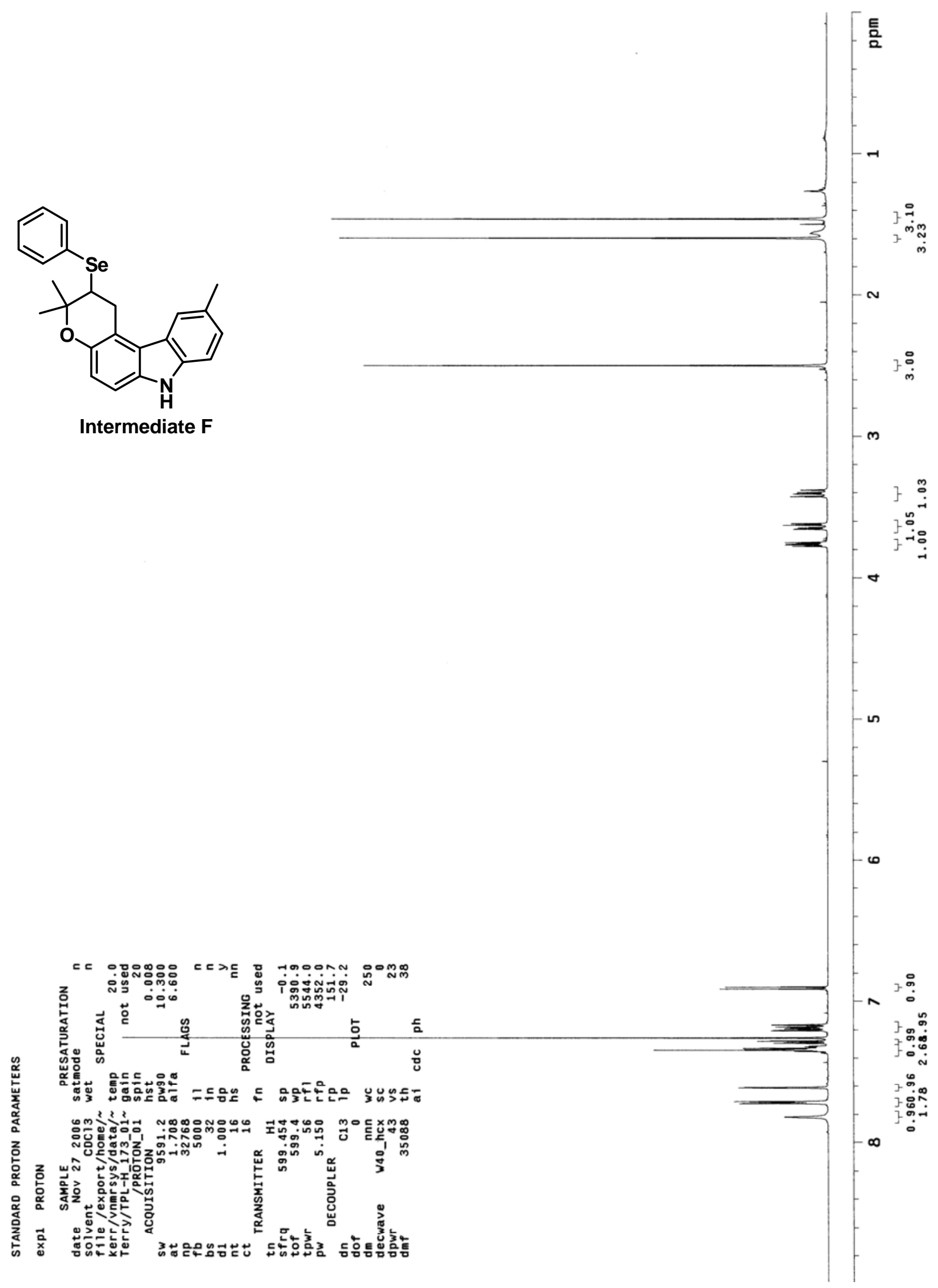




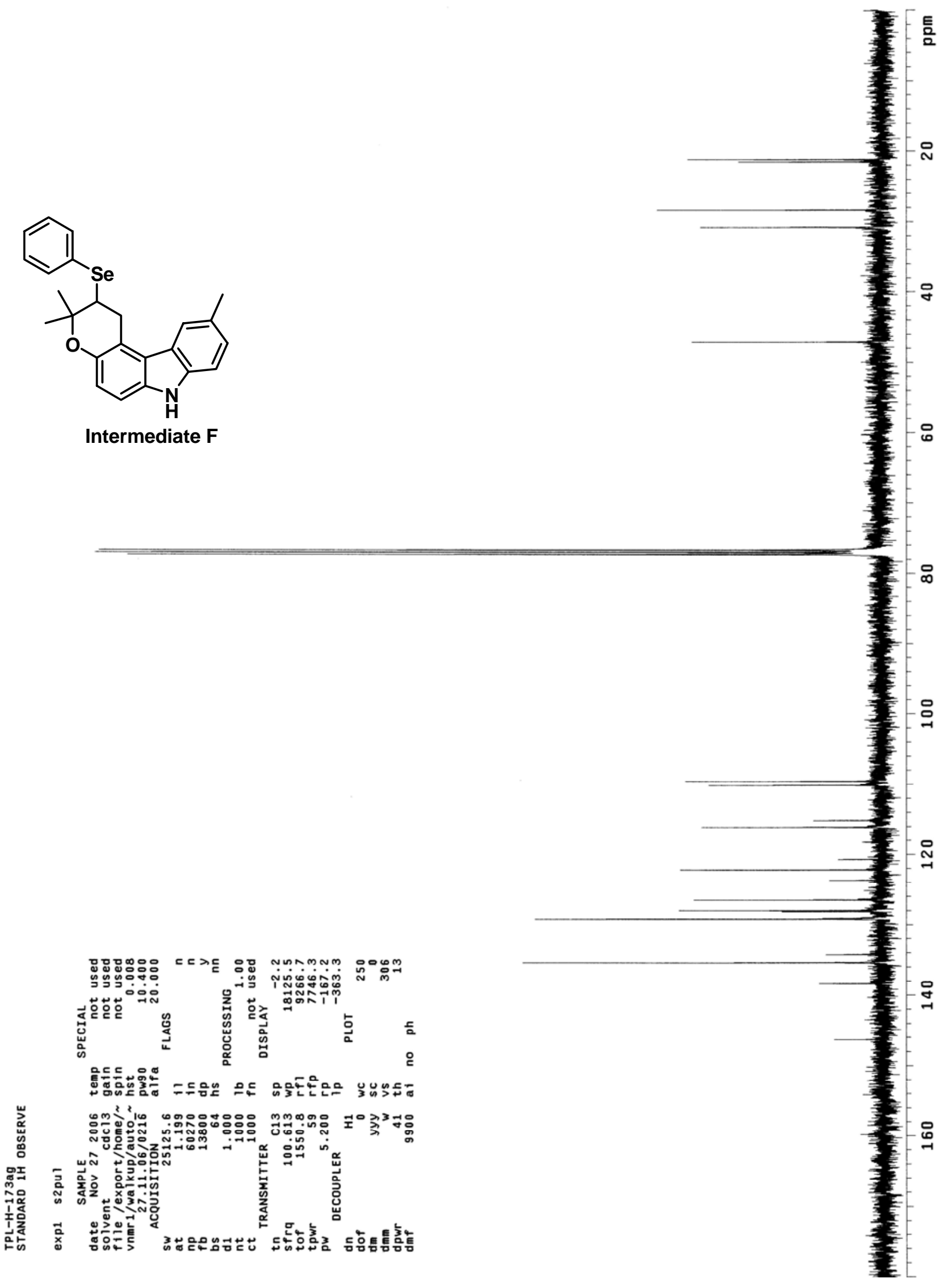




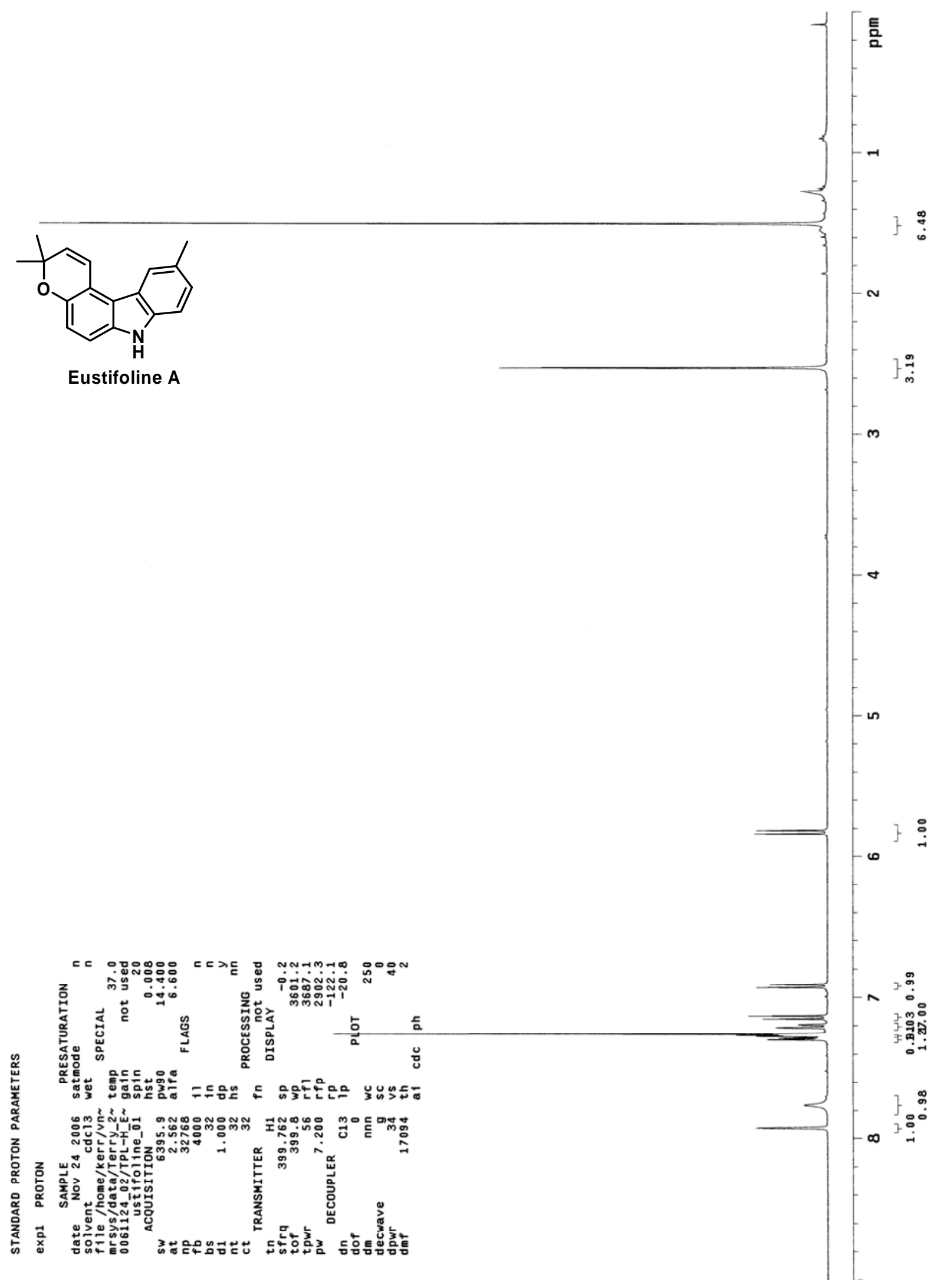




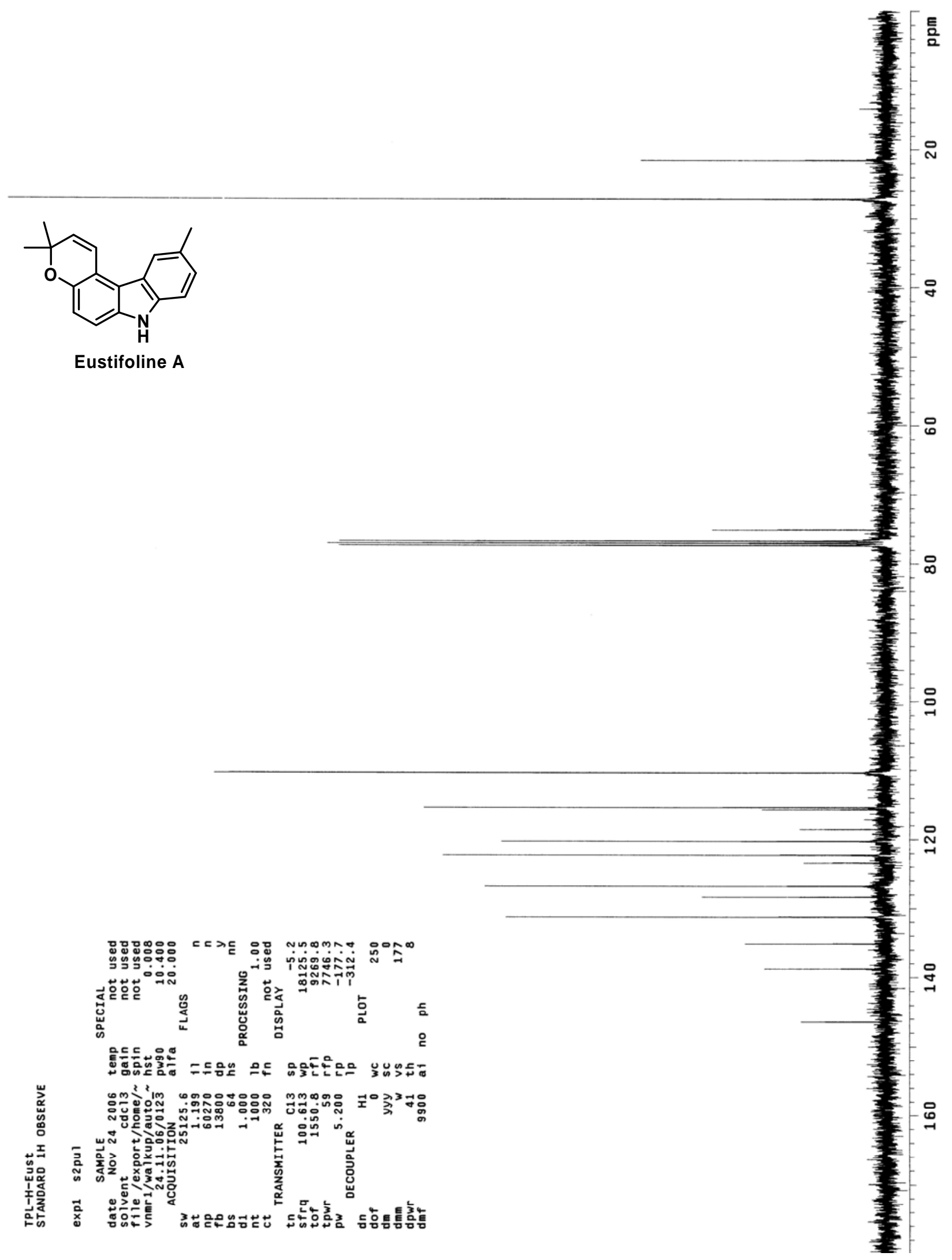




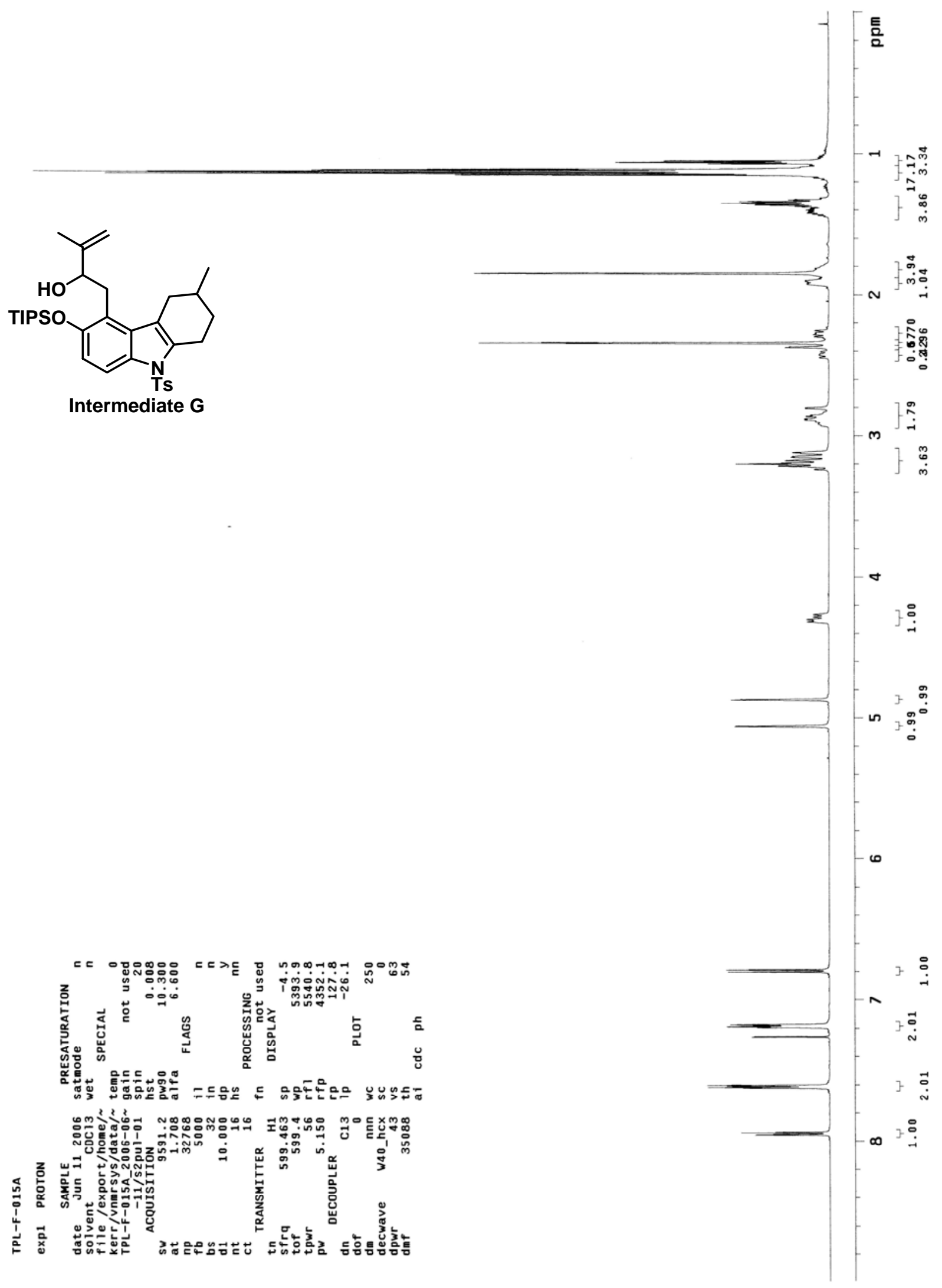




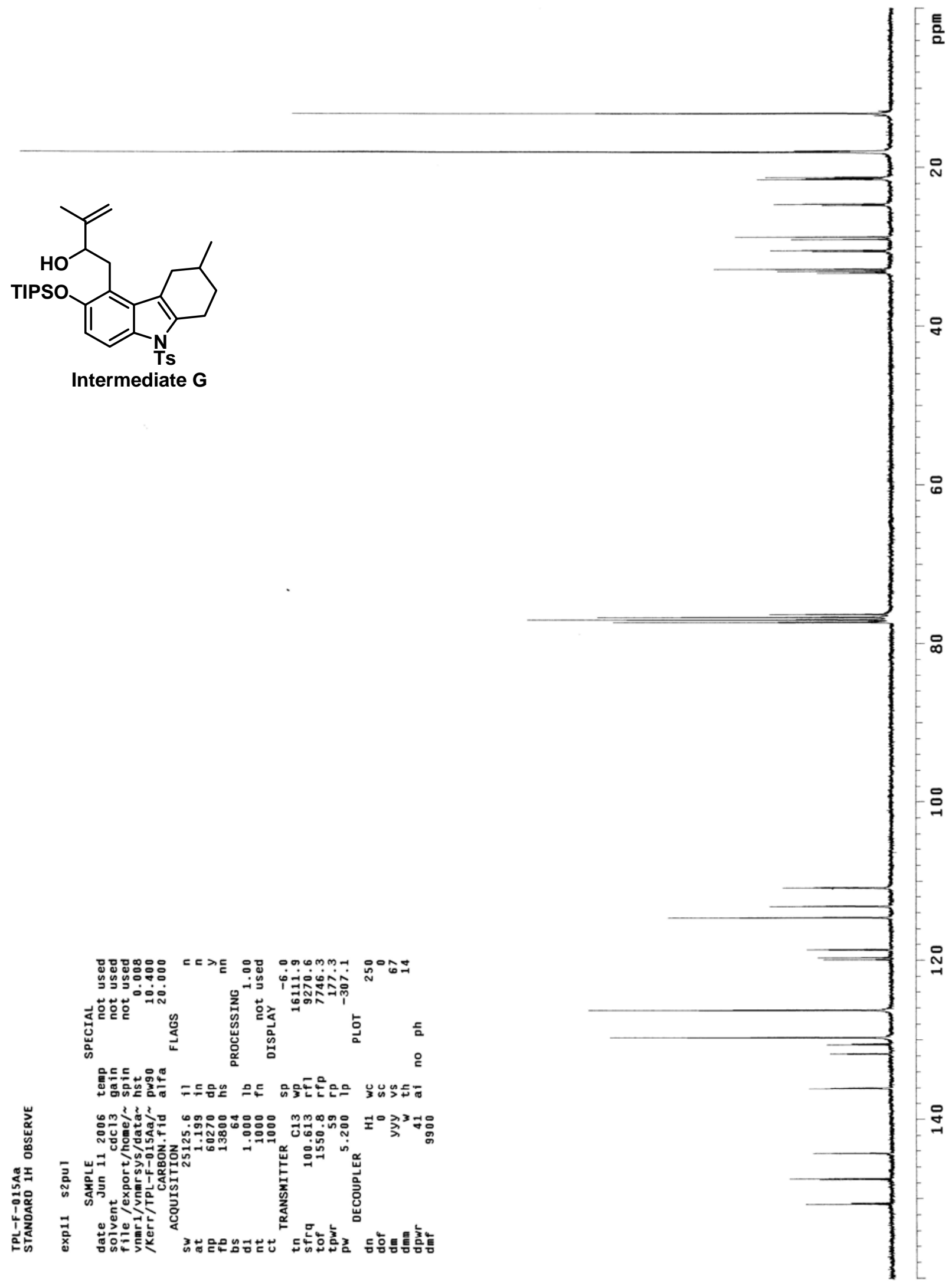




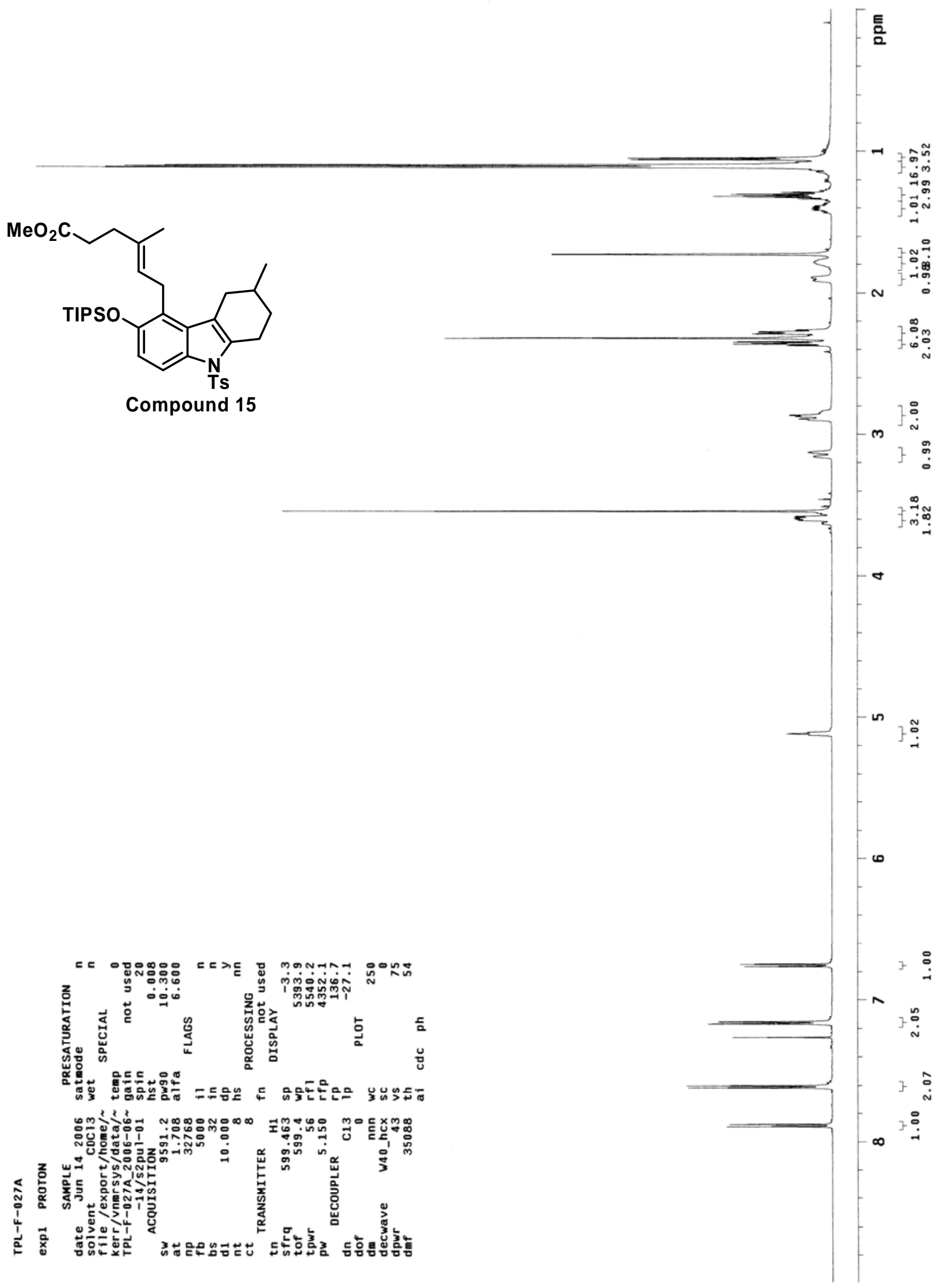




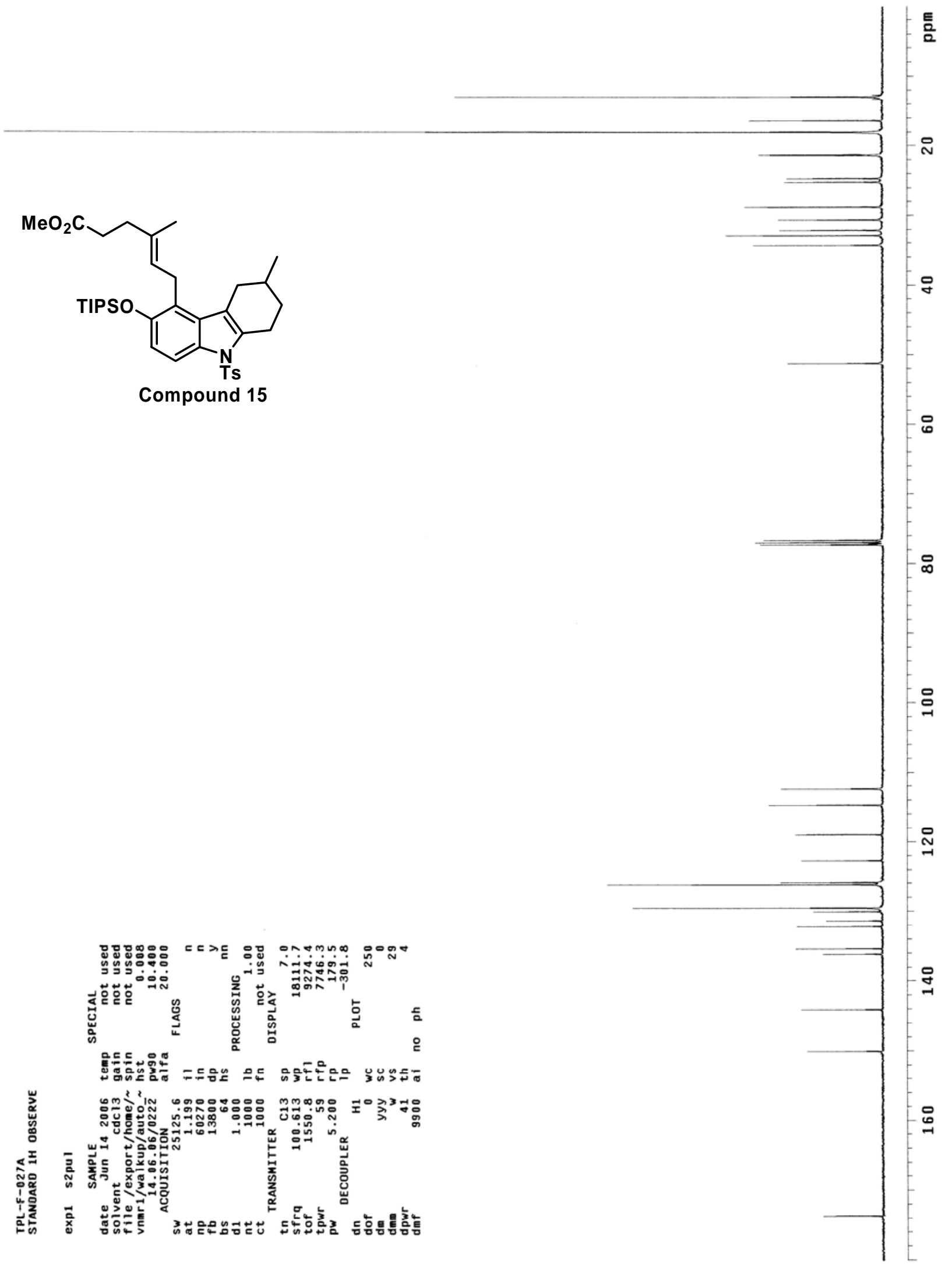




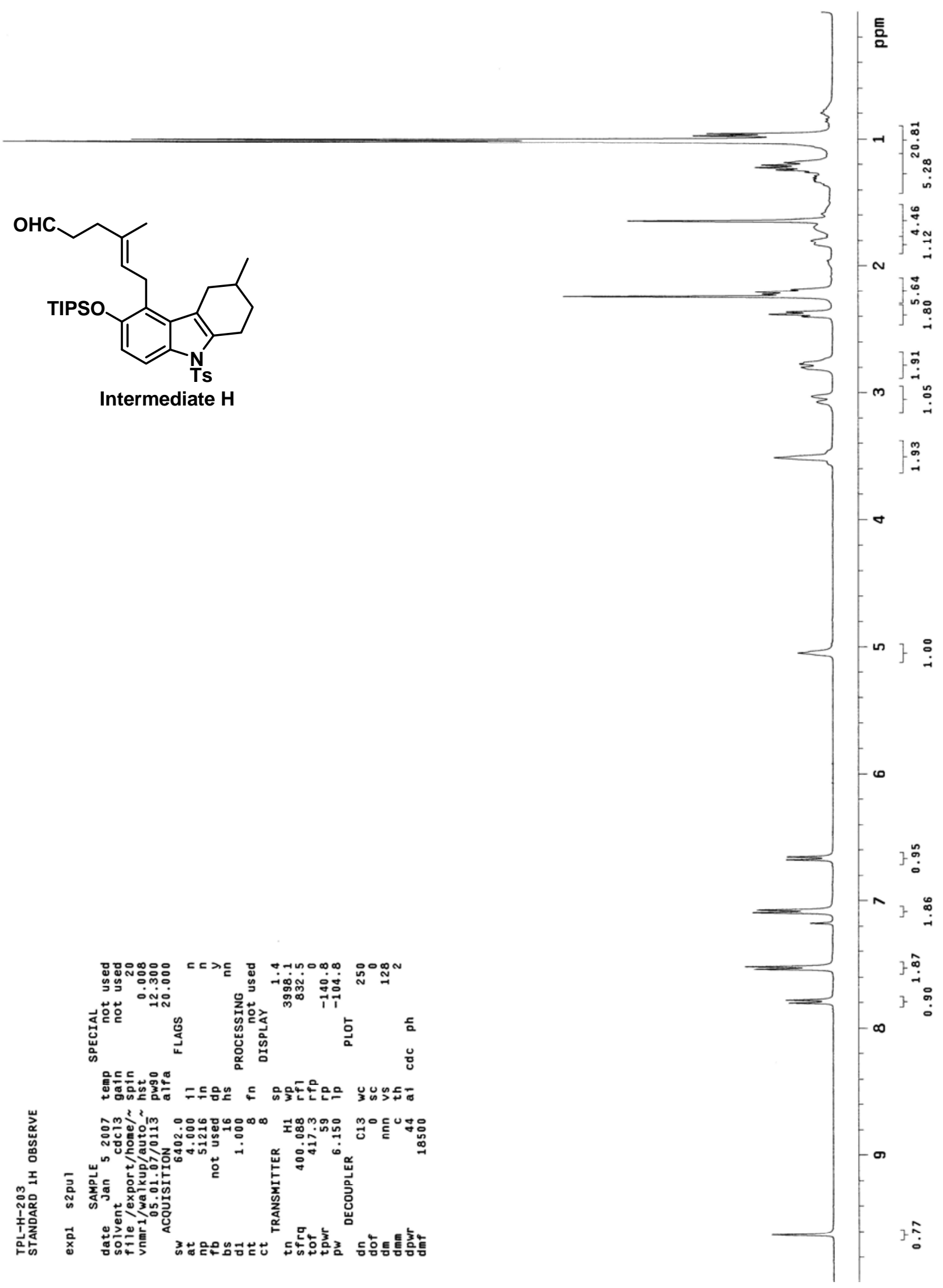




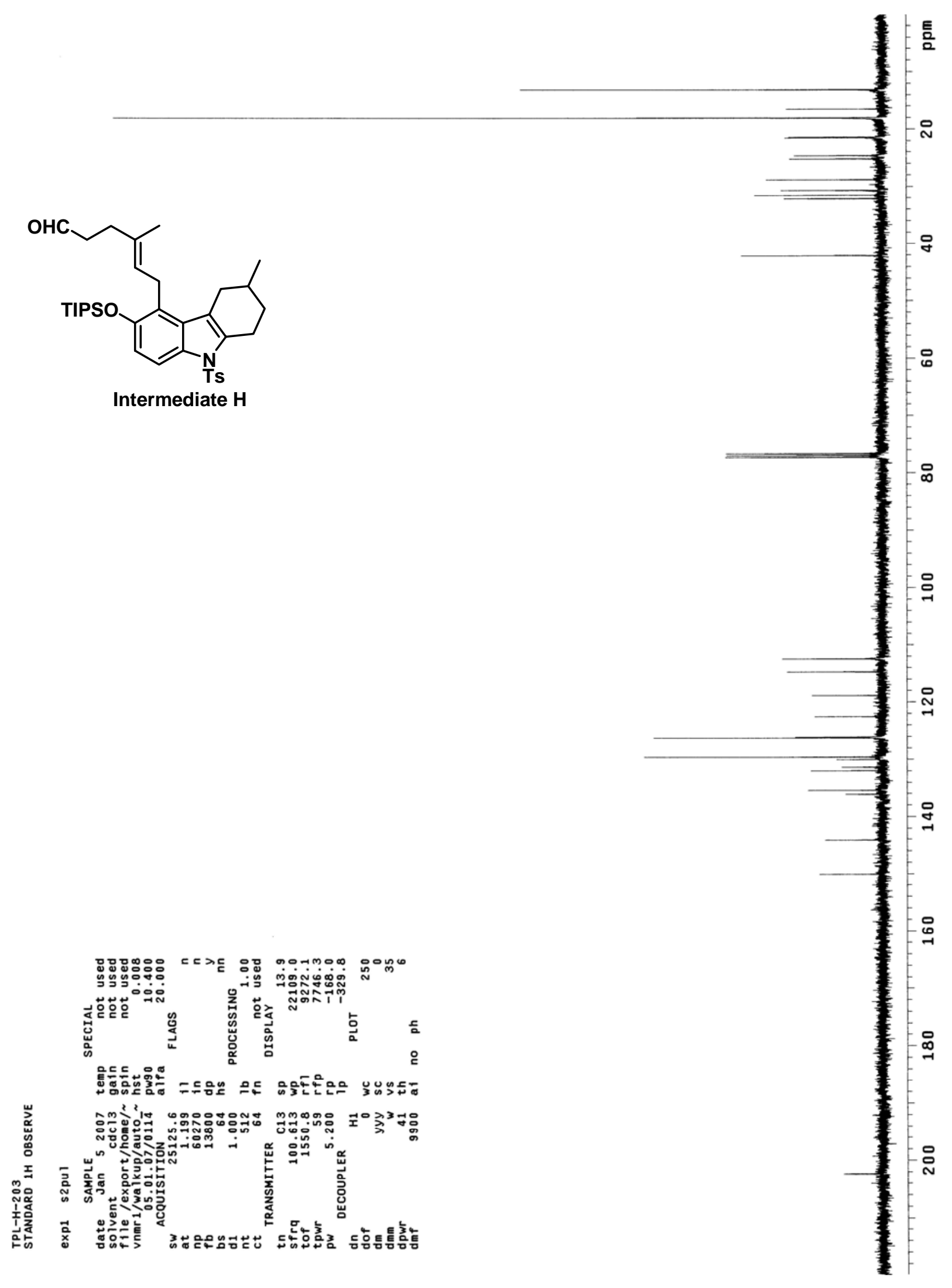




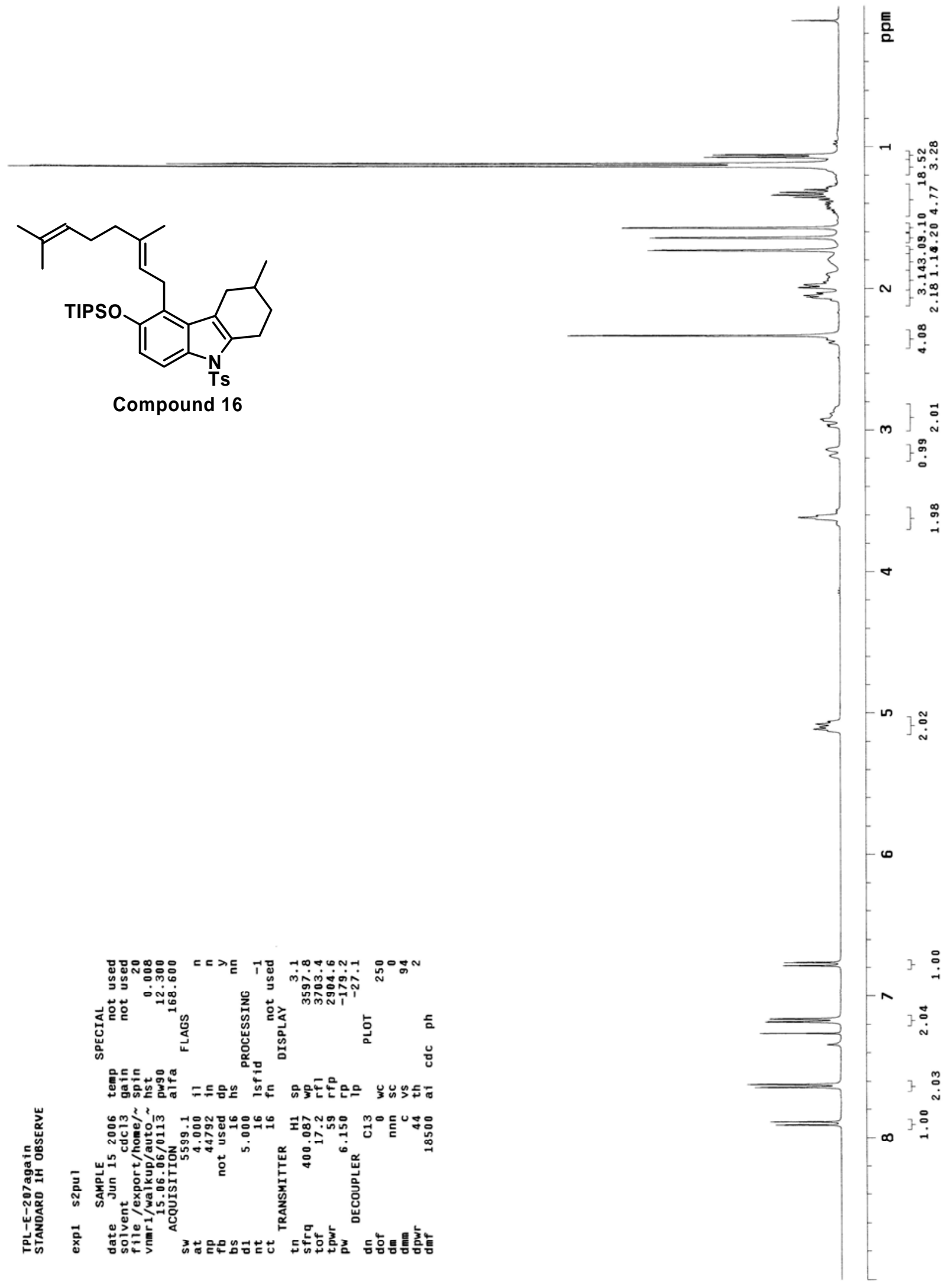




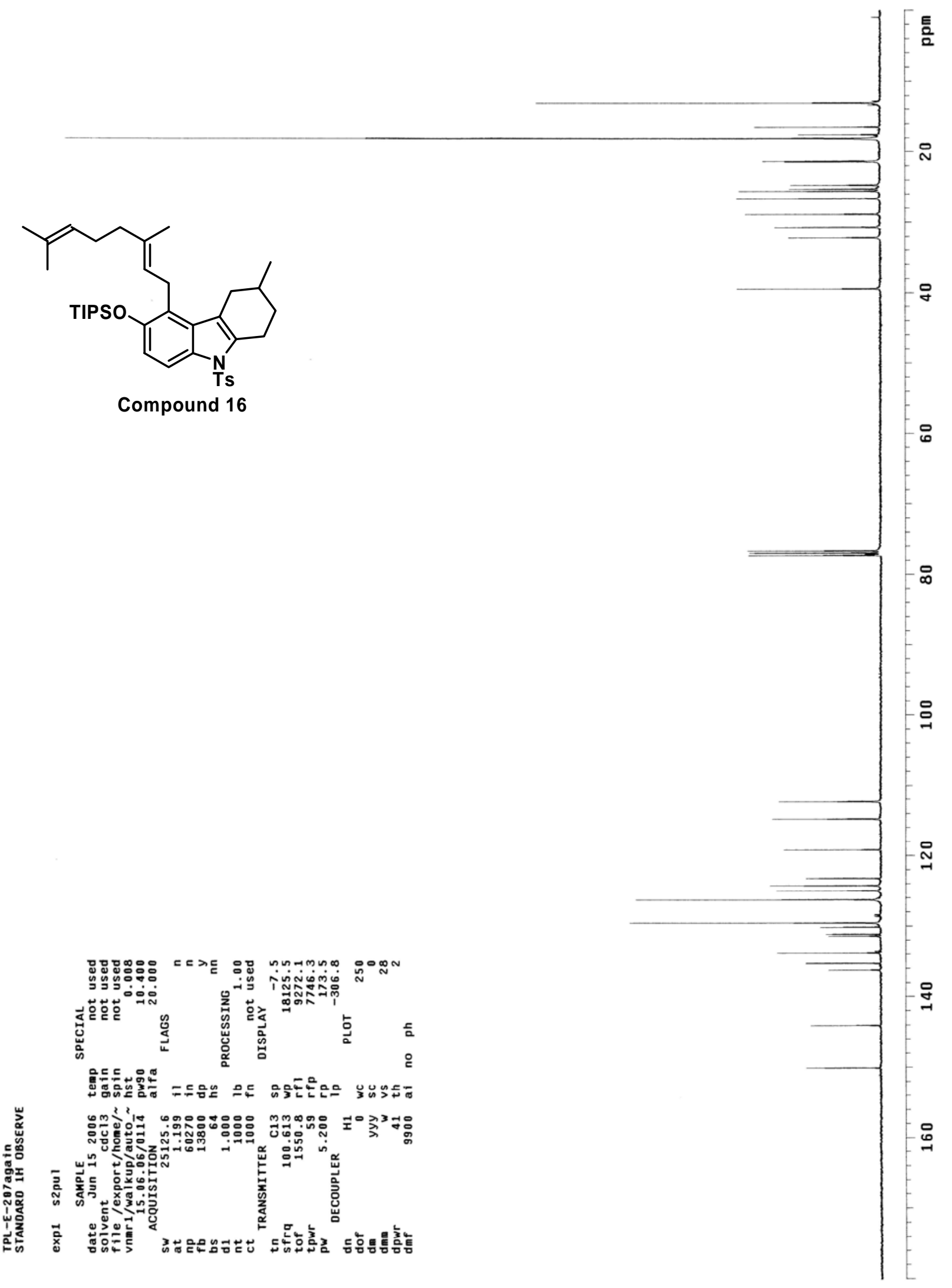




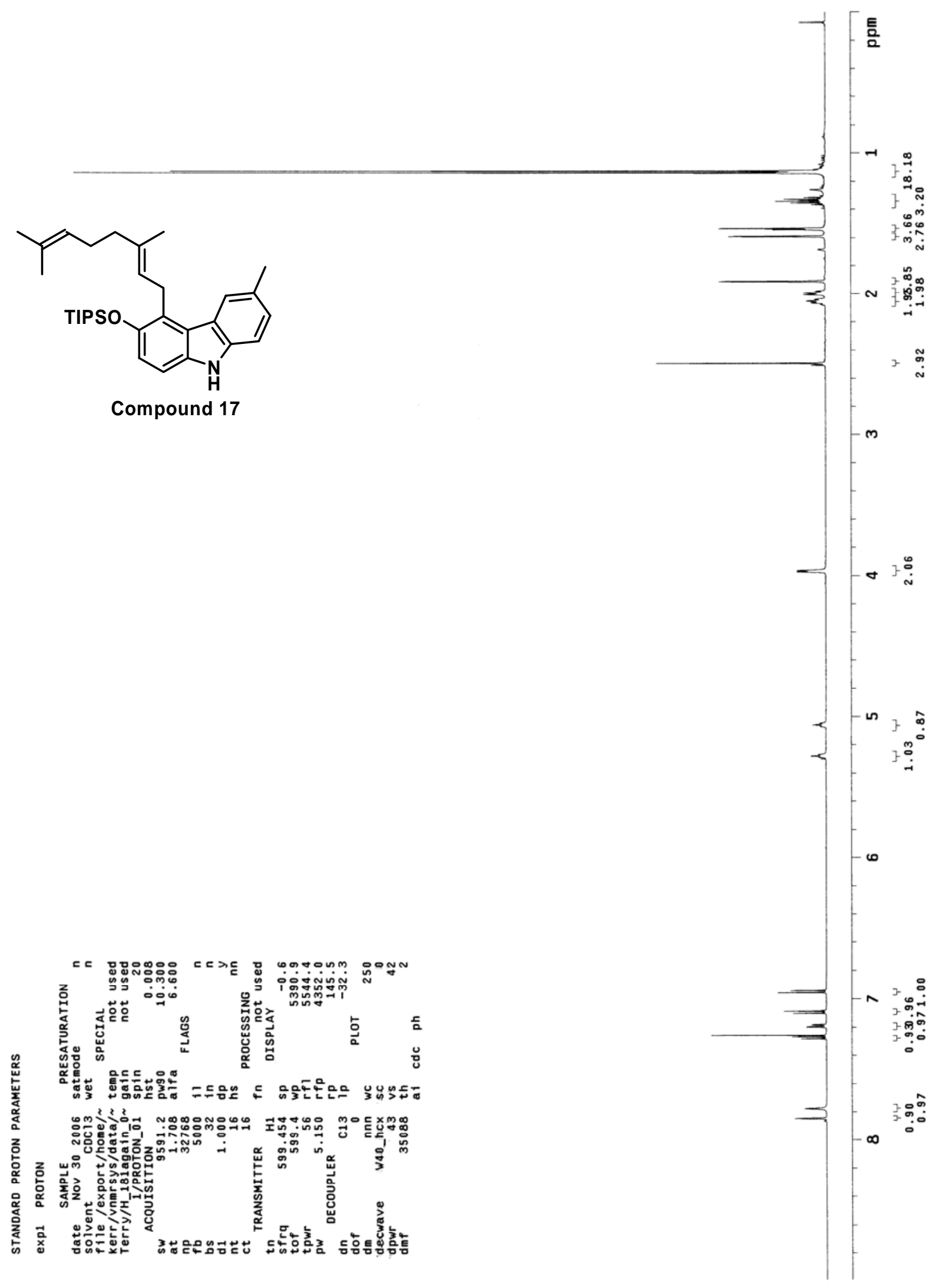




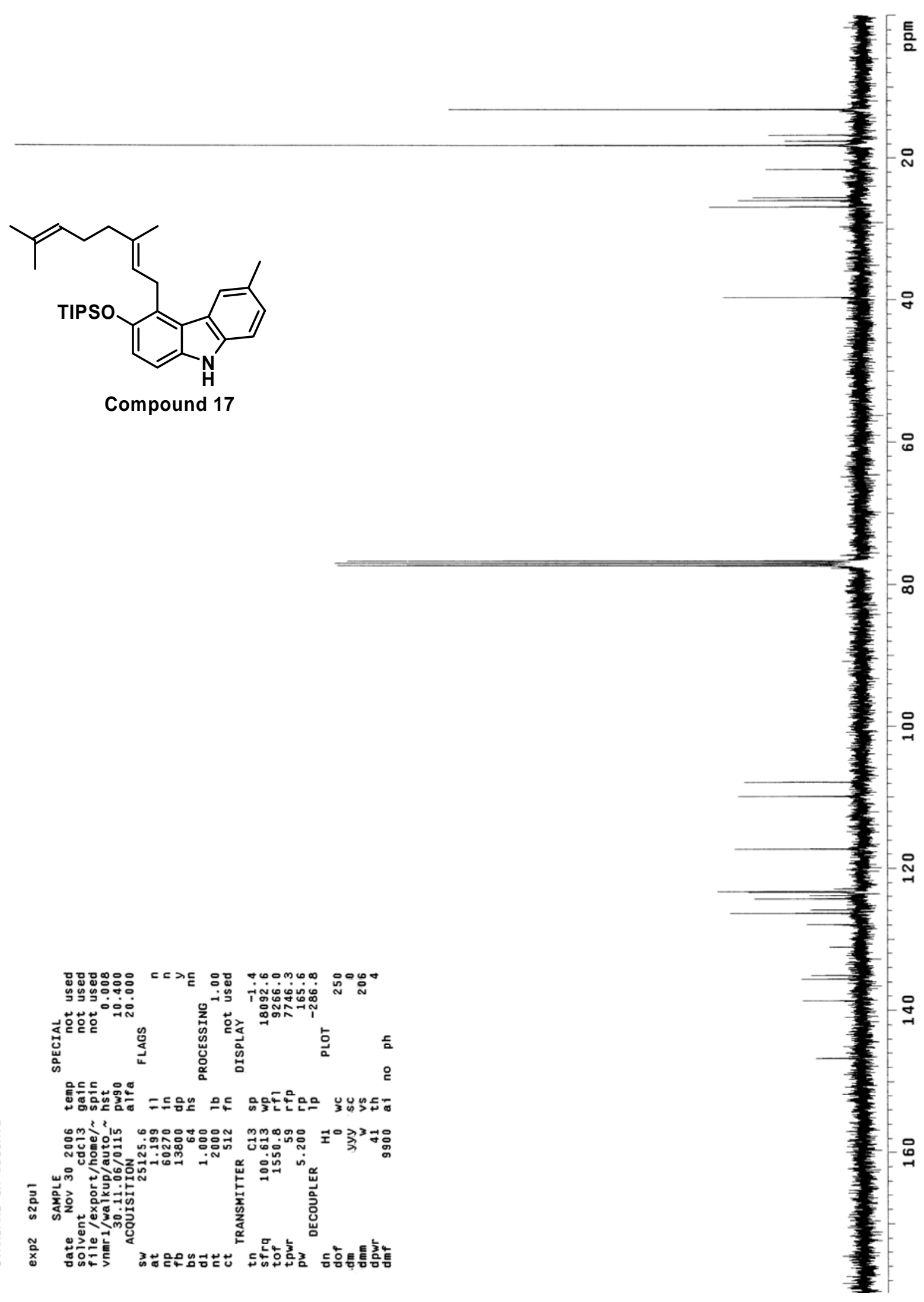




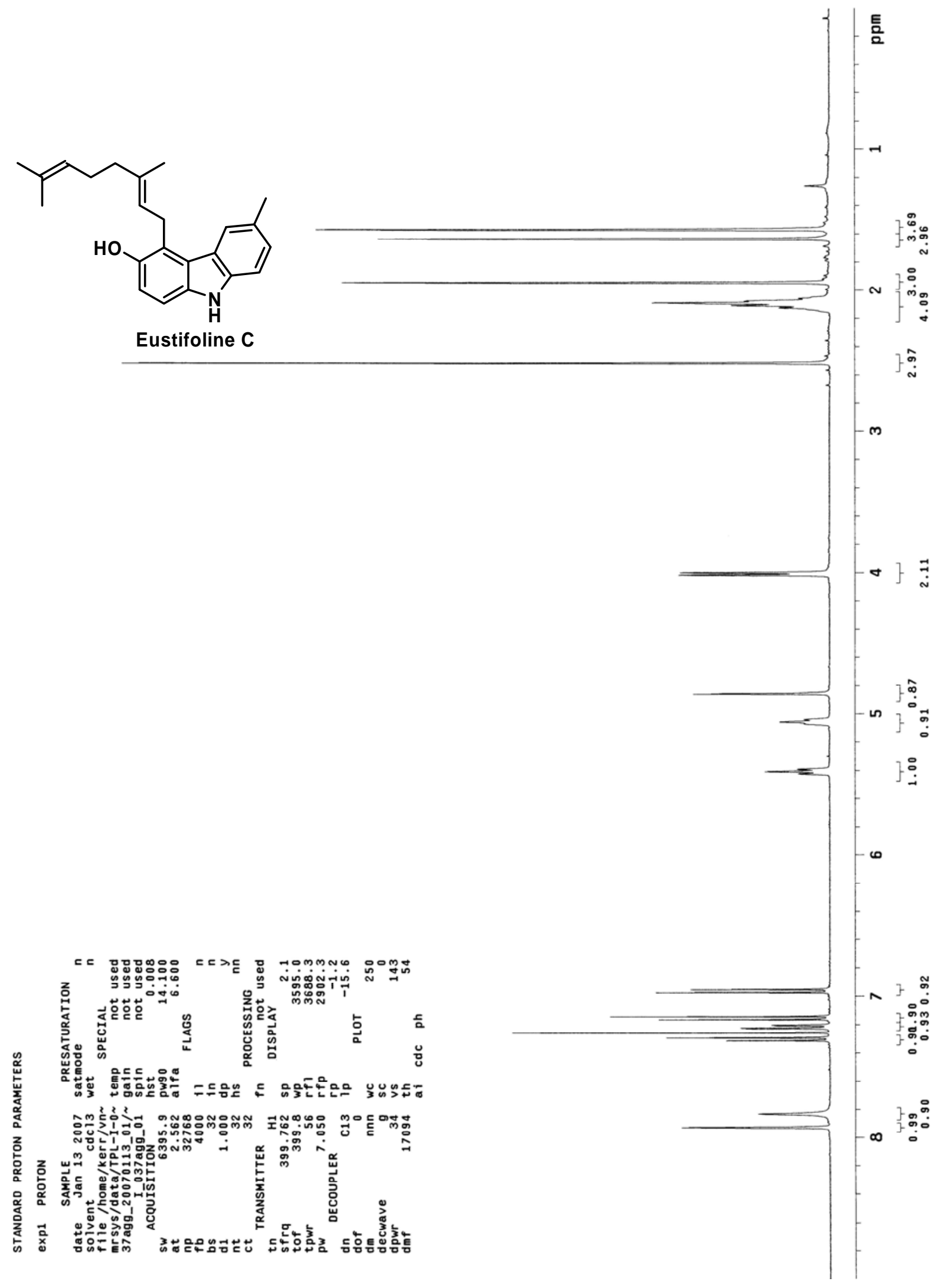




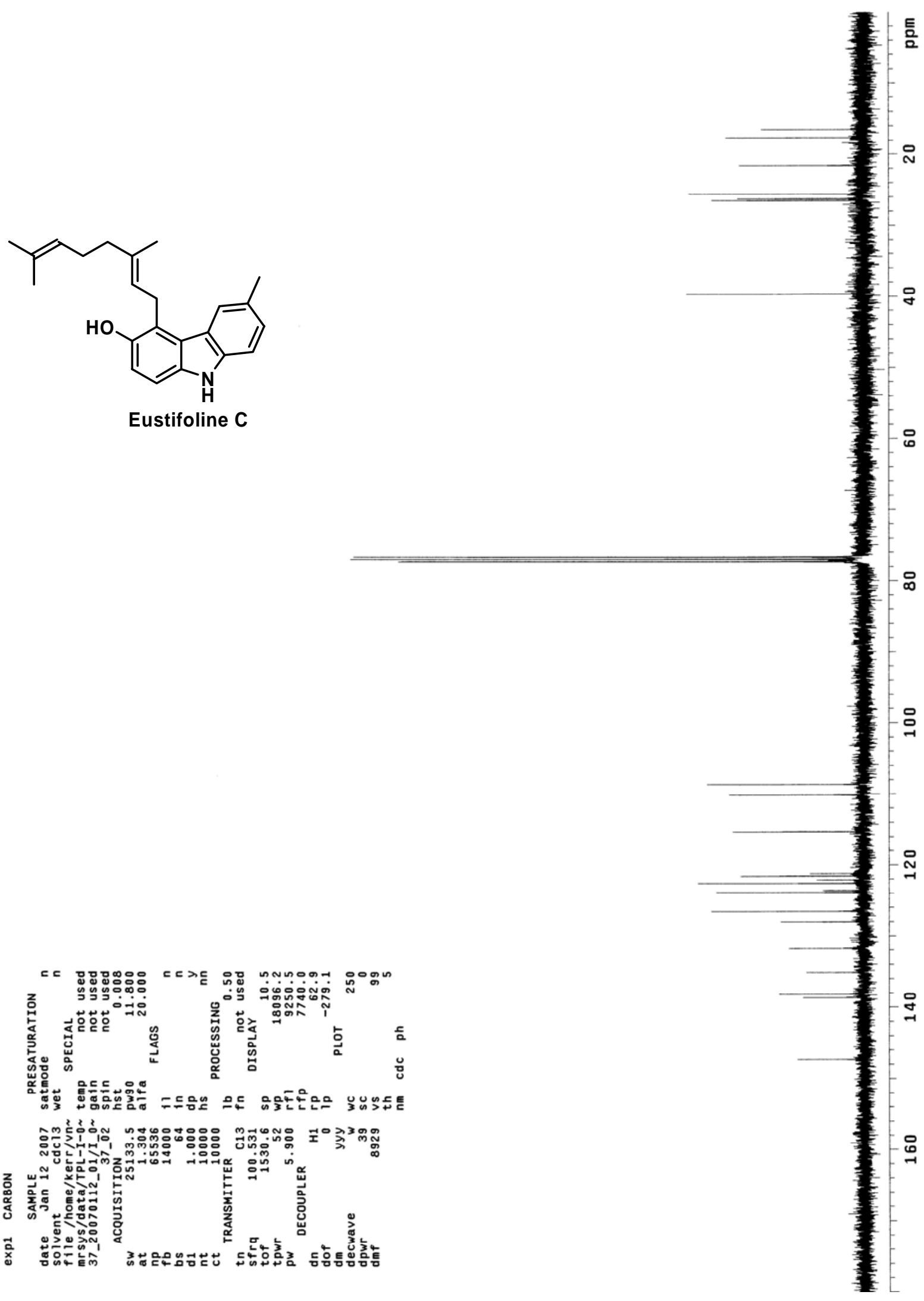




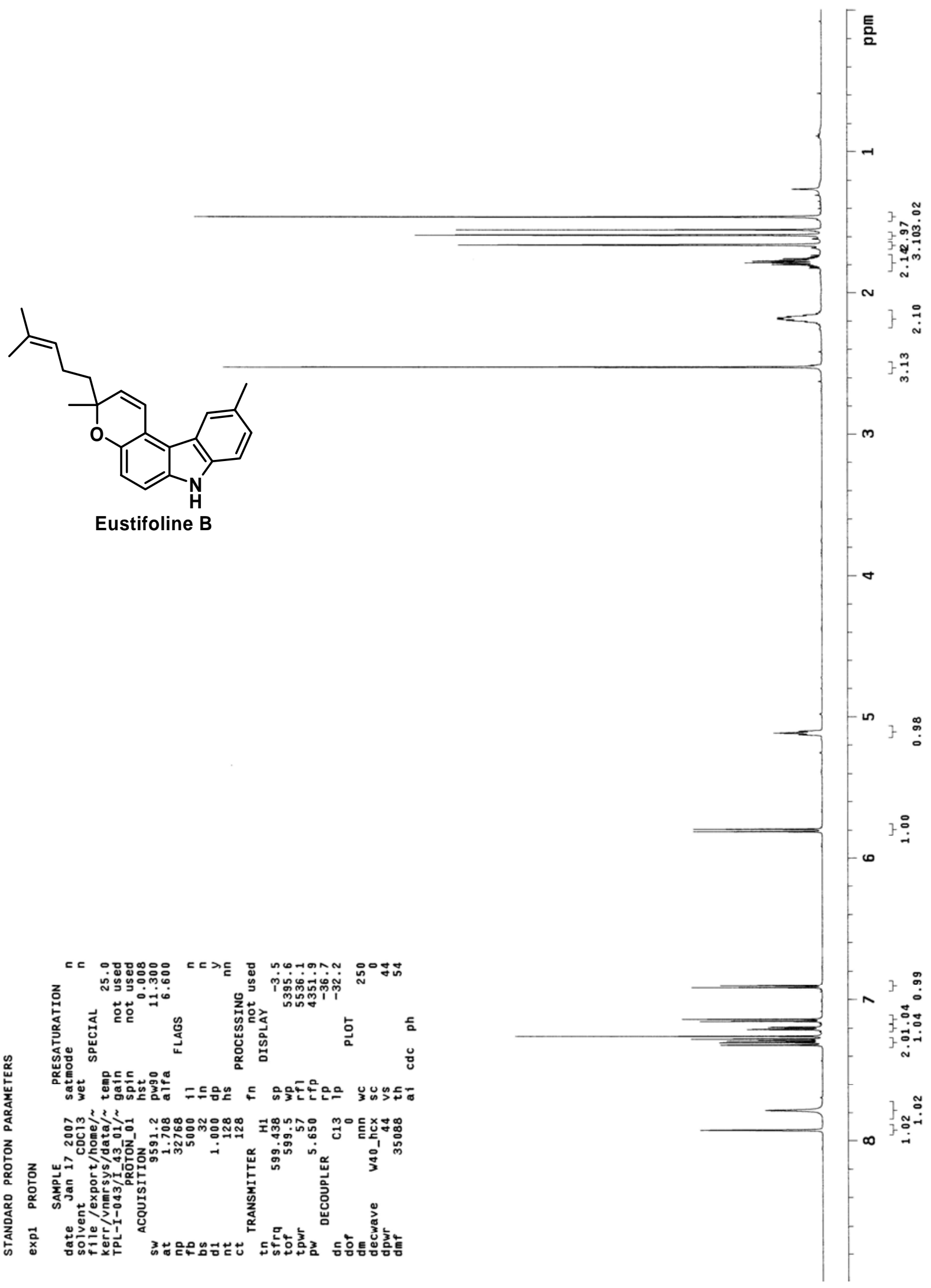




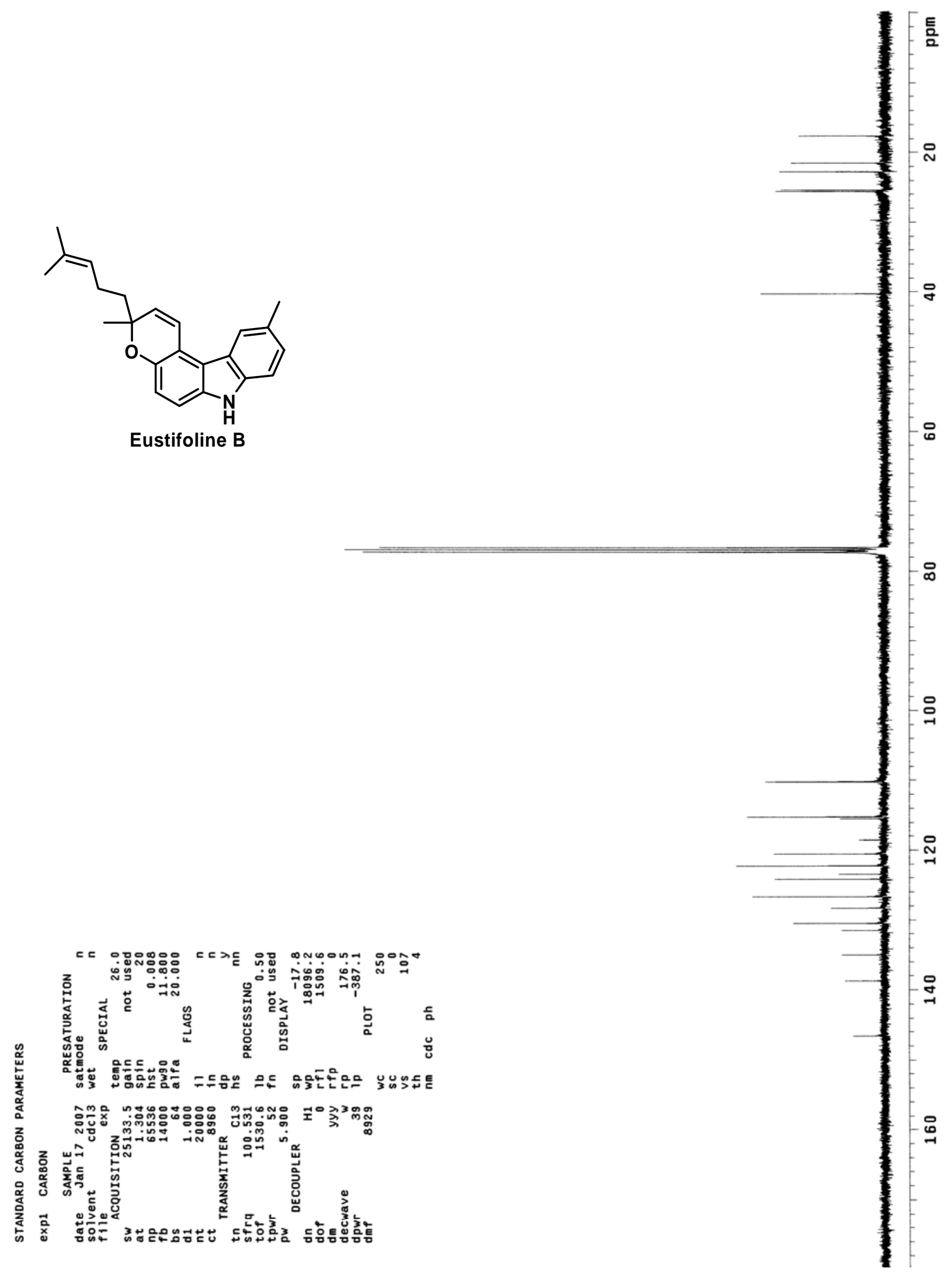

